\title{
ENGINEERING DEVELOPMENT OF ADVANCED PHYSICAL FINE COAL CLEANING FOR PREMIUM FUEL APPLICATIONS
}

US DOE Contract No. DE-AC22-92PC92208-21

Amax R\&D Subcontract No. 91445-B

Task 11:

Topical Report

\section{Commercial CWF Production Cost Study}

\author{
Prepared for: \\ Amax R\&D, Inc. \\ Golden, Colorado
}

Prepared by:

Technology \& Consulting Bechtel Corporation

San Francisco, CA

Principal Investigators:

Horst Huettenhain M. K. V. Chari

June 1997 


\section{Notice}

This report was prepared by Bechtel Corporation in the course of preparing work contracted for and sponsored by Amax R\&D. The opinions expressed in this report do not necessarily reflect those of Bechtel or Amax R\&D and references to any specific product, service, process or method does nor necessarily constitute an implied or expressed recommendation or endorsement of same. Further, neither Bechtel nor Amax R\&D makes any warranties or representations, expressed or implied, as to the fitness for particular purpose, marketability of any product, apparatus or service or the usefulness, completeness or accuracy of any processes, methods or other information described, disclosed or referred to in this report. 


\section{Contents}

$\underline{\text { Section }}$

$\underline{\text { Page }}$

1 EXECUTIVE SUMMARY $1-1$

1.1 Introduction 1-1

1.2 Conceptual Designs $1-1$

1.3 Cost of Premium CWF - Column Flotation 1-4

1.4 Cost of Premium CWF - Selective Agglomeration 1-5

1.5 Conclusions \& Recommendations 1-6

1.6 Acknowledgements 1-6

2 INTRODUCTION 2-1

3 CONCLUSIONS \& RECOMMENDATIONS 3-1

4 COMMERCIAL CWF PLANT DESIGN CRITERIA 4-1

4.1 Coal Feed Stock 4-1

4.2 CWF Specifications 4-2

4.3 Annual Capacity of the Plant 4-2

4.4 Plant Location 4-3

4.5 Plant Operating Schedule 4-3

4.6 Coal Receiving 4-3

4.7 Storage 4-3

4.8 Crushing and Grinding 4-3

4.9 Coal Cleaning Processes 4-4

4.10 Clean Coal Dewatering, Water Clarification and Tailings Handling 4-4

4.11 Tailings Disposal 4-4

4.12 Preparation of CWF 4-4

4.13 CWF Storage and Loading 4-5

5 CONCEPTUAL DESIGN OF CWF PLANT - 5-1 COLUMN FLOTATION

5.1 Process Design Criteria 5-1

5.2 Facility Description 5-1

6 CONCEPTUAL DESIGN OF CWF PLANT - SELECTIVE 6-1 AGGLOMERATION

6.1 Process Design Criteria 6-1

6.2 Facility Description 6-2 
7 COST OF PREMIUM CWF- COLUMN FLOTATION 7-1

7.1 Capital Costs 7-1

7.2 O\&M Costs and Cost of CWF 7-2

7.3 Sensitivity Analysis 7-4

8 COST OF PREMIUM CWF - SELECTIVE AGGLOMERATION 8-1

8.1 Capital Costs $\quad 8-1$

8.2 O\&M Costs and Cost of CWF 8-2

8.3 Sensitivity Analysis $8-5$

9 LIST OF ACRONYMS AND ABBREVIATIONS 9-1

$\begin{array}{ll}\text { APPENDICES A-1 } & \text { A }\end{array}$

A CAPITAL COST ESTIMATE - A-2 COLUMN FLOTATION

B CAPITAL COST ESTIMATE - A-6 SELECTIVE AGGLOMERATION

C COST SENSITIVITY ANALYSIS CALCULATIONS - A-12 COLUMN FLOTATION Tables C-1 through C-5

D COST SENSITIVITY ANALYSIS CALCULATIONS - A-17 SELECTIVEAGGLOMERATION Tables D-1 Through D-5 


\section{TABLES}

Table $\quad \underline{\text { Page }}$

5.1.1 Commercial CWF Plant- Column Flotation 5-5

5.2.1 Commercial CWF Plant- Column Flotation 5-7

Major Equipment List

6.1.1 Commercial CWF Plant- Selective Agglomeration 6-8

Process Design Criteria

6.2.1 Commercial CWF Plant- Selective Agglomeration 6-11

Major Equipment List

6.2.2 Plant 200: Crushing and Grinding- Material and Heat Balance 6-17

6.2.3 Plant 350: Selective Agglomeration- Material and Heat Balance 6-18

6.2.4 Plant 400: Clean Coal Dewatering- Material and Heat Balance 6-20

6.2.5 Plant 500: Water Clarification and Tailings Handling- 6-21

Material and Heat Balance

6.2.6 Plant 600: CWF Preparation and Loading- 6-22

Material and Heat Balance

7.1.1 Premium CWF Production- Column Flotation 7-5

Capital Cost Summary

7.2.1 Premium CWF Production- Column Flotation 7-6

Variable and Fixed O\&M Costs- Cost of CWF

7.2.2 Premium CWF Production- Column Flotation 7-8

Flocculant Consumption

7.2.3 Premium CWF Production- Column Flotation 7-9

Operating and Maintenance Personnel

7.3.1 Cost of Premium CWF - Column Flotation 7-10

Factors for Product Cost Sensitivity Analysis

7.3.2 Premium CWF Cost Sensitivity- Column Flotation 7-11

8.1.1 Premium CWF Production- Selective Agglomeration 8-6

Capital Cost Summary

8.2.1 Premium CWF Production- Selective Agglomeration 8-7

Variable and Fixed O\&M Costs- Cost of CWF

8.2.2 Premium CWF Production- Selective Agglomeration 8-9

Flocculant Consumption

8.2.3 Premium CWF Production- Selective Agglomeration 8-10

Operating and Maintenance Personnel

8.3.1 Cost of Premium CWF- Selective Agglomeration 8-11

Factors for Product Cost Sensitivity Analysis

8.3.2 Premium CWF Cost Sensitivity - Selective Agglomeration 8-12 


\section{ILLUSTRATIONS}

$\underline{\text { Figure }}$

$\underline{\text { Page }}$

1.1 Premium CWF Production - Block Flow diagram 1-8

1.2 Plant Layout 1-9

1.3 Cost of Premium CWF- Column Flotation $\quad 1-10$

1.4 Cost of Premium CWF- Selective Agglomeration 1-11

5.1 Column Flotation-Plant 100: Raw Coal Handling- 5-10

5.2 Column Flotation-Plant 200: Crushing and Grinding- 5-11

5.3 Column Flotation-Plant 300: Column Flotation 5-12

Process Flow Diagram

5.4 Column Flotation-Plant 400: Clean Coal Dewatering- 5-13

Process Flow Diagram

5.5 Column Flotation-Plant 500: Water Clarification and 5-14

Tailings Handling- Process Flow Diagram

5.6 Column Flotation-Plant 600: CWF Preparation and 5-15

Loading- Process Flow Diagram

6.1 Selective Agglomeration-Plant 100: Raw Coal Handling- 6-22

Process Flow diagram

6.2 Selective Agglomeration-Plant 200: Crushing and Grinding- 6-23

Process Flow diagram

6.3 Selective Agglomeration-Plant 350: Selective Agglomeration- 6-24

Process Flow Diagram (Sheets 1 through 5)

6.4 Selective Agglomeration-Plant 400: Clean Coal Dewatering- 6-29

Process Flow Diagram

6.5 Selective Agglomeration-Plant 500: Water Clarification 6-30 and Tailings Handling- Process Flow Diagram

6.6 Selective Agglomeration-Plant 600: CWF Preparation \& Loading- 6-31 Process Flow Diagram 


\section{Section 1 \\ Executive Summary}

\subsection{INTRODUCUTION}

Bechtel, together with Amax Research and Development Center (Amax R\&D), has prepared this study which provides estimates of the cost of production of premium quality coal-water slurry fuel (CWF) in a commercial plant. Two plant scenarios are presented, one using advanced column flotation technology to clean the coal and the other, selective agglomeration for the same purpose. The study forms part of US Department of Energy program "Engineering Development of Advanced Physical Fine Coal Cleaning for Premium Fuel Applications," (Contract No. DE-AC22-92PC92208), under Task 11, Project Final Report.

The primary objective of the Department of Energy program is to develop a design base for prototype commercial advanced fine coal cleaning facilities capable of producing ultra-clean coals suitable for conversion to stable and highly loaded CWF. The fuels should contain less than $2 \mathrm{lb}$ of ash/MBtu (860 grams of ash/GJ) of HHV and preferably less than $1 \mathrm{lb}$ of ash/MBtu (430 grams of ash/GJ). Advanced fine coal cleaning technologies to be employed are advanced column froth flotation and selective agglomeration. It is further stipulated that operating conditions during the advanced cleaning process should recover at least 80 percent of the heating value in the run-of-mine source coal. These goals for ultra-clean coal quality are to be met under the constraint that annualized coal production costs do not exceed $\$ 2.50 / \mathrm{MBtu}(\$ 2.37 / \mathrm{GJ})$, including the mine mouth cost of the raw coal. This cost compares with a No. 6 fuel oil cost of approximately $\$ 3.35 \mathrm{MBtu}(\$ 3.17 / \mathrm{GJ})$.

Laboratory, bench-scale, and Process Development Unit (PDU) testing were completed earlier under the research program with selected raw coal samples. A PDU with a capacity of $2 \mathrm{st} / \mathrm{h}$ was designed by Bechtel and installed at Amax R\&D, Golden, Colorado for process evaluation and testing. The tests successfully demonstrated the capability of column flotation as well as selective agglomeration to produce ultra-clean coal at specified levels of purity and recovery efficiency. Test results and the experience gained during the operation of the PDU have provided valuable insights into the processes studied the design bases for commercial plants.

To facilitate the cost estimating effort, conceptual designs for two commercial plants have been developed each using an advanced coal cleaning technology.

\subsection{CONCEPTUAL DESIGNS}

Based on process design bases obtained from the test work and a set of project design criteria, two sets of conceptual designs for commercial CWF production plants have been developed, one using column flotation and the other, selective agglomeration. 


\subsubsection{Plant Design Criteria}

The following design criteria have been adopted for the plant designs.

Coal Feed Stock Bituminous high-volatile compliance coals which meet ash liberation requirements for advanced cleaning processes are suitable feed stocks for the plants. Prewashed Taggart (Upper Elkhorn No. 3), Elkhorn No. 3, and Sunnyside seam coals and run of mine (ROM) Hiawatha seam coal were found to fulfill these requirements during evaluations conducted under this research program. Other coals, such as No. 2 Gas (Campbell Creek), could also be suitable. The named coals are low in organic form of sulfur which cannot be eliminated by physical coal cleaning processes such as column flotation and selective agglomeration.

Premium CWF Specifications In addition to ash and sulfur content limitations noted in the program objectives there are limits on slurry viscosity and slurry heating value to make the CWF an attractive fuel. Discussions with industry indicate that the viscosity of the fuel should not exceed $500 \mathrm{cp}$. at a $100 \mathrm{~s}^{-1}$ shear rate. Its HHV should be not less than $8900 \mathrm{Btu} / \mathrm{lb}$ which translates into a solids concentration of not less than 60 percent by weight of ultra-clean (dry) coal.

Plant Capacity and Location The plant designs are based on an annual out-put capacity of 1.5 million st (US ton) of ultra-clean coal (dry basis) formulated into 2.5 million st of CWF containing 60 dry solids percent by weight. This amount of fuel is adequate to fuel $500 \mathrm{MW}$ of electric power plant. Other recent coal preparation studies have also used similar capacity as the basis for economic assessments.

The plants are designed to operate all 24 hours of the day in three shifts and all 7 days of the week. However, 2 shifts in a week and 2 weeks in a year are set aside for maintenance work. Based on the expected percentage yield of clean coal (weight recovery) and plant availability, the hourly design in-put capacities of the two plant scenarios have been calculated and found to be nearly the same at $233 \mathrm{st} / \mathrm{h}$ (dry basis). The plant using column flotation is expected provide a clean coal yield of 90.3 percent and have a plant availability of 81 percent. The second design based on selective agglomeration is expected to provide a higher yield of 93 percent, but, being more complex, have a lower plant availability of 79 percent.

The plants are located in the Ohio valley in an industrial area with good infrastructure facilities and close to a city like Cincinnati or Cleveland with many potential consumers of CWF in the proximity.

The selective agglomeration plant requires a significant amount of low pressure steam. It would perfectly complement an existing power plant which could provide low pressure steam as a by-product. The plant could be situated where steam could be purchased for approximately $\$ 3.00 / \mathrm{MBtu}$. The cost estimates are based on buying steam for that price. 


\subsubsection{Plant Description}

Figure 1.1 shows a block flow diagram of the facilities. A plant layout is shown in Figure 1.2. Except for the coal cleaning sections, Plant 300 Column Flotation and Plant 350 Selective Agglomeration as shown in the block flow diagram, the two designs are very similar. The description provided below addresses both plant designs.

Coal Receiving and Storage (Plant 100) Coal feed to the plant, 2 inch $x 0$ in size, is supplied in open gondola type rail cars which are unloaded by a car dumper at a rate of $2000 \mathrm{st} / \mathrm{h}$. Storage facilities for raw coal at the plant site include three concrete silos with a total capacity of 30,000 st. This capacity equals a 5-day consumption.

Crushing and Grinding (Plant 200) After an initial crushing to size $1 / 2$ in. $x 0$ in hammer mills, the coal is ground in wet closed-circuit ball mills to size 325 mesh (45 microns) (D80) at a rate of $233 \mathrm{st} / \mathrm{h}$ (dry basis). Two parallel and identical trains are used in the grinding section. The ground slurry is delivered to the coal cleaning section, Plant 300 (or Plant 350).

Column Flotation (Plant 300) Twelve identical and parallel trains of column flotation equipment are used to clean the coal. Each train has a capacity to process approximately $20 \mathrm{st} / \mathrm{h}$. Each flotation column has a diameter of 14 feet.

Selective Agglomeration (Plant 350) The selective agglomeration section comprises ten identical trains each with a capacity of $23 \mathrm{st} / \mathrm{h}$. Heptane is used as the bridging liquid which is recovered and reused in the process. Unlike the column flotation plant, plant design for the selective agglomeration process includes special facilities like the gas holders, cooling water ponds and flares as shown in the Layout, Figure 1.2.

Clean Coal Dewatering (Plant 400) Clean coal from column flotation (or selective agglomeration) is dewatered using vacuum filters. This plant section includes 6 identical and parallel filtration trains.

Water Clarification and Tailings Handling (Plant 500) Tailings from column flotation (or selective agglomeration) are thickened and clarified water is recovered in this plant section. The water is recycled in the plant. It is cooled with chilled water in the selective agglomeration case before recycling.

The thickened tailings are filtered and loaded into trucks for disposal as a solid waste.

$\underline{C W F \text { Preparation and Loading (Plant 600) }}$ Clean coal filter cake from Plant 400 is mixed with dispersant additive A-23 and the solids content adjusted by adding measured amounts of water. The product slurry is pumped to slurry storage tanks for loading into rail cars or pumping by pipeline to clients located in the area. The storage tanks have a total capacity equivalent to 48 hours of plant production. 


\subsection{COST OF PREMIUM CWF - COLUMN FLOTATION}

The estimated capital cost of the plant based on column flotation is $\$ 69.6$ million (First Quarter -1997). CWF production cost (without considering the cost of coal in the product) including capital charges is estimated at $\$ 0.91 / \mathrm{MBtu}$.

Major elements of the cost are as follows:

\begin{tabular}{|l|l|l|l|}
\hline Cost Element & $\$ /$ MBtu & $\%$ & \\
\hline Capital charges and interest on & & & \\
Working Capital & 0.27 & 29.1 & \\
CWF additive, A-23 & 0.23 & 25.6 & \\
Labor & 0.13 & 14.6 & \\
Electric power & 0.11 & 12.3 & \\
Flotation reagents \& & & & \\
Flocculant & 0.07 & 7.5 & \\
Btu Loss & 0.05 & 5.5 & \\
Others & $\underline{0.05}$ & $\underline{5.4}$ & Less cost of coal \\
Total Cost of CWF & 0.91 & $\mathbf{1 0 0}$ & \\
\hline
\end{tabular}

The above break down of costs of $\$ 0.91$ is shown graphically in Figure 1.3. Including the cost of coal delivered to plant site at $\$ 1.24 / \mathrm{MBtu}$, the total cost of production of premium CWF comes to $\$ 2.15 / \mathrm{MBtu}(\$ 1.24+\$ 0.91)$.

The target set under the research program for the cost of production of premium CWF is $\$ 2.50 / \mathrm{MBtu}$ including the mine mouth cost of coal. The above mentioned cost of $\$ 2.15 / \mathrm{MBtu}$ includes a transportation cost of $0.20 \$ / \mathrm{MBtu}$ for the raw coal. Based on mine mouth coal cost, the estimated cost of production of premium CWF is $\$ 1.95 / \mathrm{MBtu}$ ( $\$ 2.15$ less $\$ 0.20$ ) which is well below the targeted cost of production. This makes it an attractive replacement fuel for oil at current prices of petroleum products.

Sensitivity Studies One of the major elements in the cost of manufacture of CWF is the cost of A-23 additive dispersant. Use of the additive becomes necessary to meet the specified 60 percent solids loading of the product. If the solids loading could be reduced to around 54 percent, the slurry could be produced without the use of this additive. In such an event the total cost of CWF would be reduced from $\$ 2.15 / \mathrm{MBtu}$ to $\$ 1.92$ representing a reduction of $\$ 0.23 / \mathrm{MBtu}$. With a reduced solids content of 54 percent, the $\mathrm{HHV}$ of premium fuel is lowered to $8100 \mathrm{Btu} / \mathrm{lb}$, a value below the target specification which calls for a minimum HHV of $8900 \mathrm{Btu} / \mathrm{lb}$. It is believed that for the user, the penalty for reduced HHV will be more than off-set by the reduction of $\$ 0.23 / \mathrm{MBtu}$ in fuel costs. 
A series of sensitivity analysis have been performed to evaluate the sensitivity of the cost of production of CWF to variations in other selected cost components. In addition to capital cost and the cost of raw coal, the factor that could affect the production cost most significantly, as may be expected, is the annual production rate.

\subsection{COST OF PREMIUM CWF - SELECTIVE AGGLOMERATION}

The estimated capital cost of the plant based on selective agglomeration is $\$ 97.2$ (First Quarter -1997) million. CWF production cost (without considering the cost of coal in the product) including capital charges is estimated at $\$ 1.18 / \mathrm{MBtu}$. Major cost elements are as follows:

\begin{tabular}{|l|l|l|l|}
\hline \multicolumn{1}{|c|}{ Cost Element } & \$/MBtu & $\%$ & \\
\hline Capital charges and & & & \\
Interest on Working Capital & 0.37 & 31 & \\
CWF additive, A-23 & 0.23 & 20 & \\
Labor & 0.17 & 15 & \\
Electric power & 0.15 & 13 & \\
Steam & 0.13 & 11 & \\
Others (including Heptane) & $\underline{0.13}$ & $\underline{10}$ & Less coal cost \\
Total Cost of CWF & 1.18 & 100 & \\
\hline
\end{tabular}

The above break down of costs of $\$ 1.18$ is shown graphically in Figure 1.4. Including the cost of coal delivered to plant site at $\$ 1.24 / \mathrm{MBtu}$, the total cost of production of premium $\mathrm{CWF}$ is estimated at $\$ 2.42 / \mathrm{MBtu}(\$ 1.24+\$ 1.18)$.

The above mentioned cost of $\$ 2.42 / \mathrm{MBtu}$ includes a transportation cost of $0.20 \$ / \mathrm{MBtu}$ for the raw coal to the plant site. Based on mine mouth coal cost, the estimated cost of production of premium CWF is $\$ 2.22 / \mathrm{MBtu}$ ( $\$ 2.42$ less $\$ 0.20$ ). This value is well below the targeted cost of production of $\$ 2.50 / \mathrm{MBtu}$ set for the research program based on mine mouth cost of coal.

Sensitivity Studies A major element in the cost of manufacture of CWF is the cost of A-23 additive dispersant. Use of the additive becomes necessary to meet the specified 60 percent solids loading of the product. If the solids loading could be reduced to around 54 percent, the slurry could be produced without the use of this additive. In such an event the total cost of CWF would be reduced from $\$ 2.42 / \mathrm{MBtu}$ to $\$ 2.19$ representing a reduction of $\$ 0.23 / \mathrm{MBtu}$. A reduction in the solids content to 54 percent lowers the HHV of premium to $8,100 \mathrm{Btu} / \mathrm{lb}$, a value below the target specification of $8,900 \mathrm{Btu} / \mathrm{lb}$. It is believed that the penalty for the reduced HHV will be more than off-set to the consumer by the reduction of $\$ 0.23 / \mathrm{MBtu}$ in fuel costs.

A series of sensitivity analysis was performed to evaluate the sensitivity of the cost of production of CWF to variations in other selected cost input parameters. In addition to 
capital cost and the cost of raw coal, the factor that could affect the production cost most significantly, as may be expected, is the annual production rate.

\subsection{CONCLUSIONS \& RECOMMENDATIONS}

The estimated cost of commercial production of premium CWF using either column flotation or selective agglomeration is encouraging. Column flotation, in particular, is more promising. This process, in spite of its lower energy and weight recovery, is found more economical than selective agglomeration while offering a comparable quality product. Total processing cost with column flotation at $\$ 0.91 / \mathrm{MBtu}$ is significantly lower than the cost of $\$ 1.18 / \mathrm{MBtu}$ estimated for the plant using the selective agglomeration.

As found during CWF cost sensitivity analysis, one of the significant factors that could vitally affect production costs is the annual sustainable production rate. Product costs would escalate drastically if the annual production rate of 1.5 million st cannot be achieved in plants built according to conceptual designs presented herein. Two significant technical factors that could adversely affect production are: (a) reduced plant availability due to worse than anticipated plant operability or maintenance requirements (b) feed coal harder to grind than expected. This will reduce the grinding capacity and thus the plant out-put.

These technical uncertainties are best resolved by operating experience with a larger scale plant and for a longer term than was possible with the PDU phase of the program. It was noticed during the conceptual design stage that plants with a capacity of 1.5 million st/year of ultra-clean coal will need 12 parallel trains of commercial size flotation columns or ten parallel trains of commercial size equipment for the selective agglomeration plant. This would suggest installation of demonstration/production plant using a single train of commercial size equipment with a capacity ranging from 125,000 to 150,000 st $/ y$.

Another issue of uncertainty is the acceptability of the product. Before long-term commitments could be made, all potential clients would need verification, by meaningful plant scale testing, of the suitability of premium CWF for their applications. A single train demonstration/production plant of the capacity suggested will enable production of adequate quantities of premium CWF for this purpose.

The demonstration/production plant is preferably built close to a coal mine so that costs associated with coal transportation, refuse disposal and rail car unloading facilities can be eliminated or minimized.

\subsection{ACKNOWLEDGMENTS}

The project team consisted of Cyprus Amax Minerals Company through its subsidiaries Amax Research \& Development Center (Amax R\&D) and Cyprus Amax Coal Company (Midwest and Cannelton Division), Bechtel Technology \& Consulting of Bechtel National Inc., Arcanum Corp. (of Ann Arbor, Michigan), Center for Applied Energy 
Research (CAER) of the University of Kentucky, and Center for Coal and Mineral Processing (CCMP) of the Virginia Polytechnic Institute and State University. Entech Global managed the project for Amax R\&D. Dr. John Dooher of Adelphi University and DR. Douglas Keller, Jr. of Syracuse University were consultants to the project. 


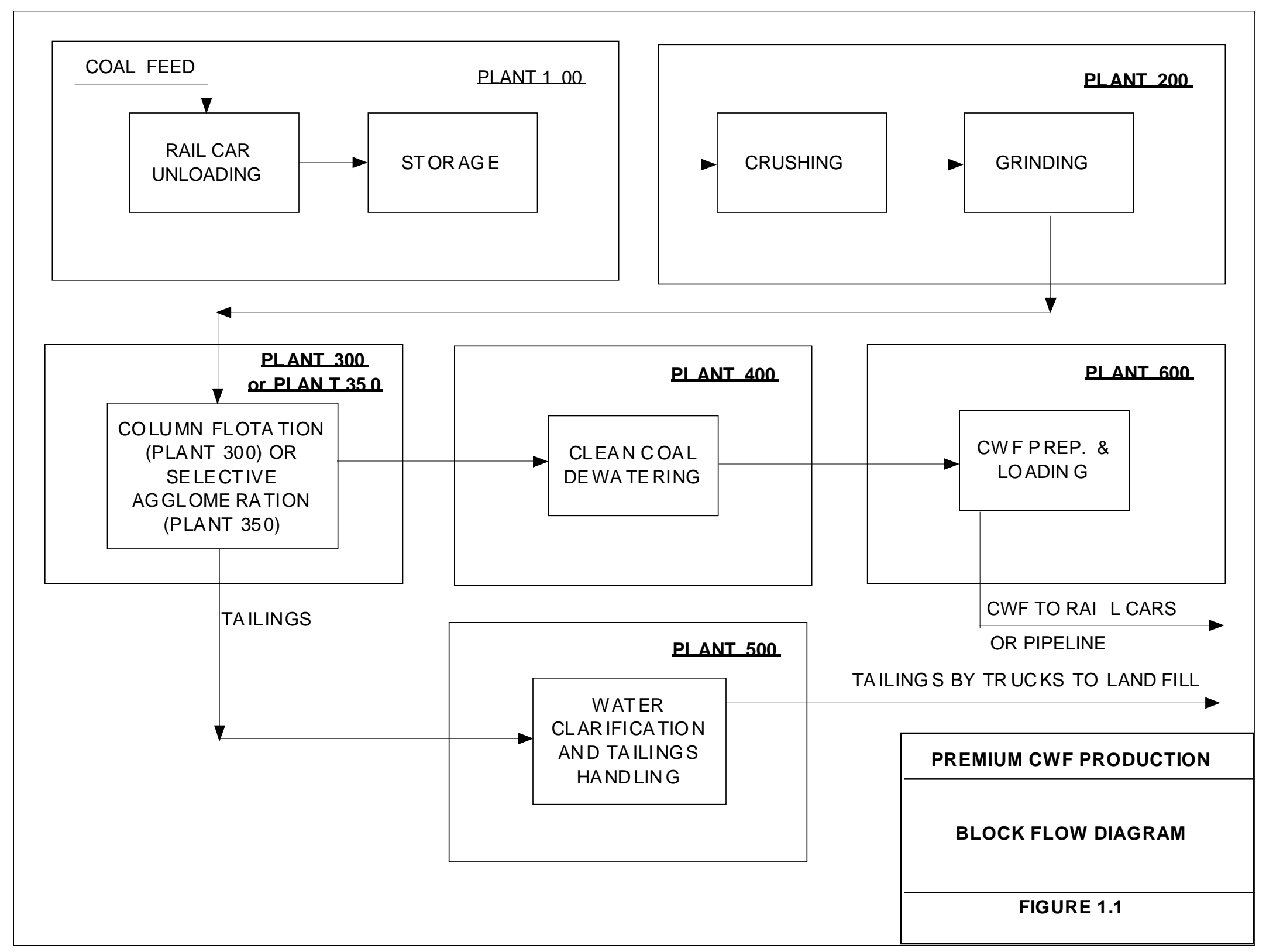




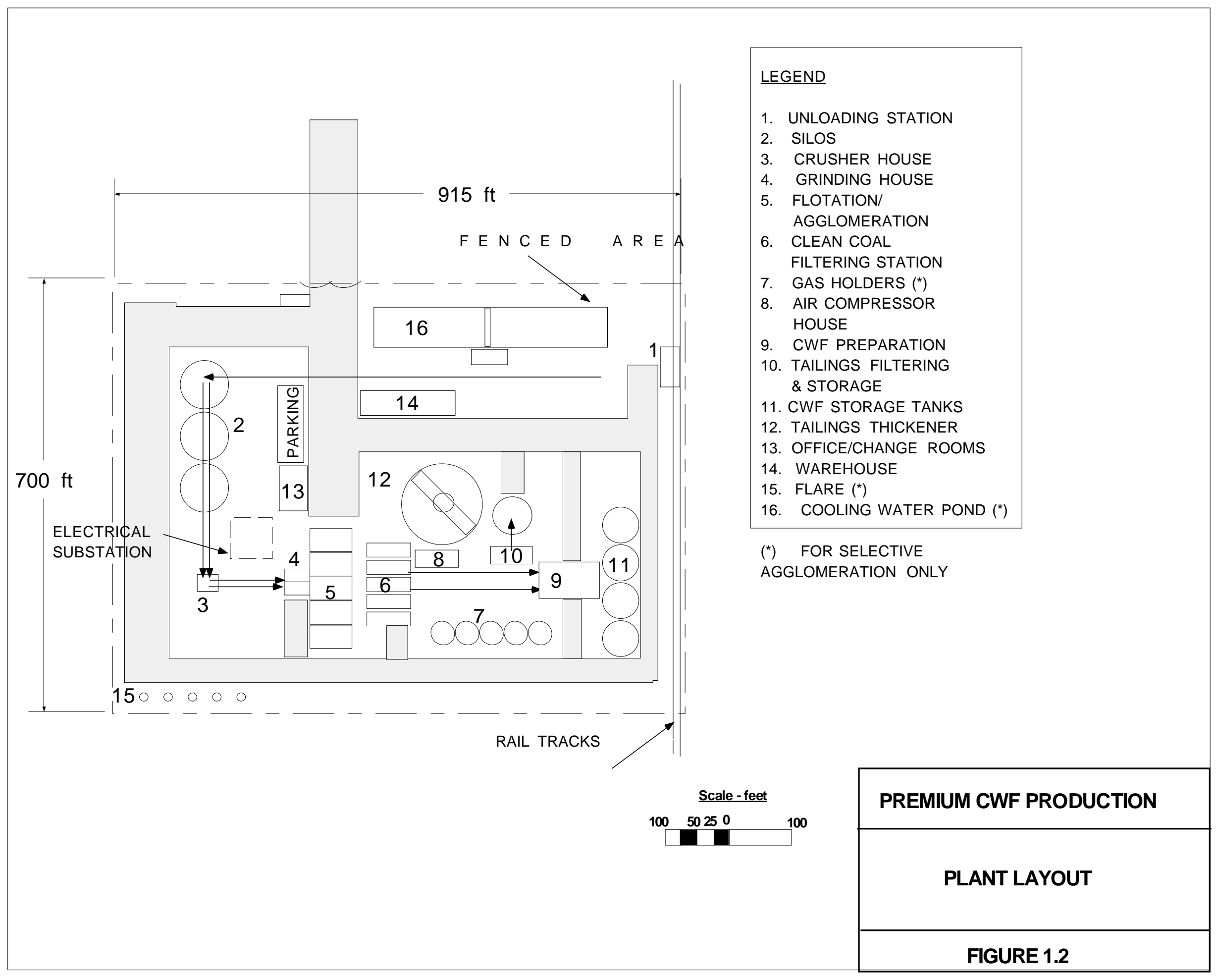




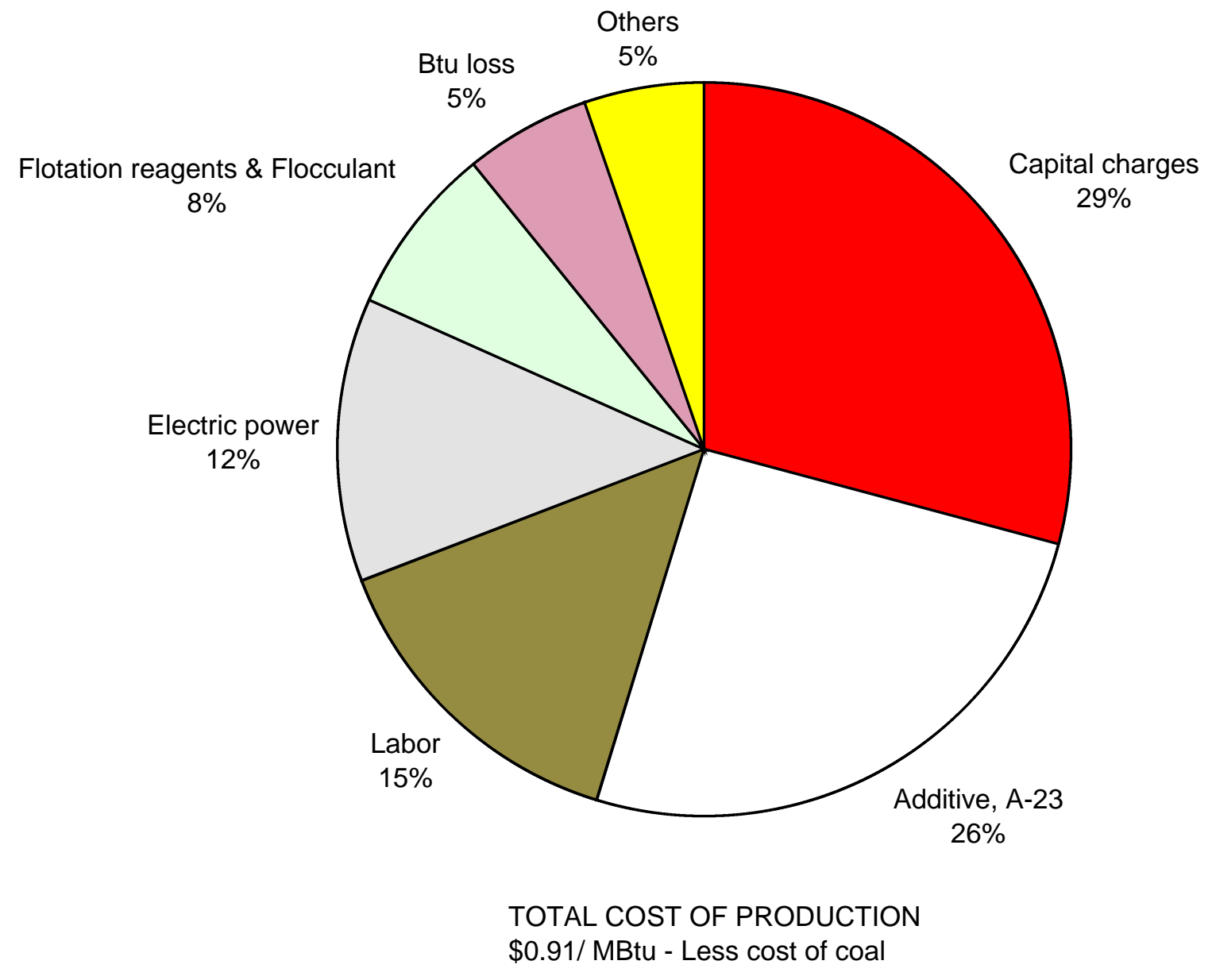

$\square$ Capital charges

$\square$ Additive, A-23

$\square$ Labor

$\square$ Electric power

$\square$ Flotation reagents \& Flocculant

$\square$ Btu loss

$\square$ Others

PREMIUM CWF PRODUCTION

COST OF CWF SELECTIVE AGGLOMERATION

FIGURE 1.3 


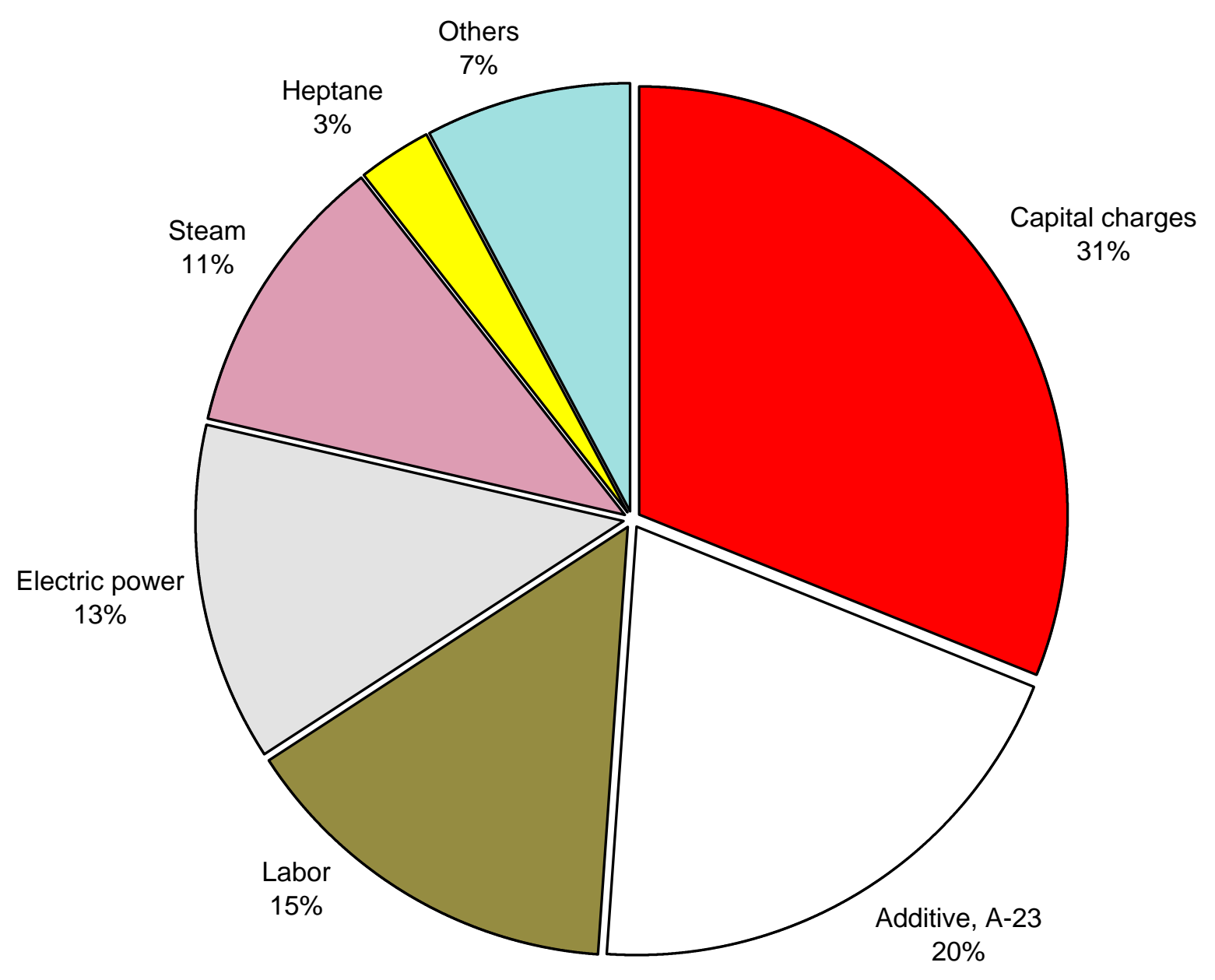

$\square$ Capital charges

$\square$ Additive, A-23

$\square$ Labor

$\square$ Electric power

$\square$ Steam

$\square$ Heptane

$\square$ Others

TOTAL COST OF PRODUCTION

$\$ 1.18$ / MBtu - Less cost of coal

FIGURE 1.4 


\section{Section 2 \\ Introduction}

Bechtel, together with Amax Research and Development Center (Amax R\&D), has prepared this study which provides conceptual cost estimates for the production of premium quality coal-water slurry fuel (CWF) in a commercial plant. Two scenarios are presented, one using column flotation technology and the other the selective agglomeration to clean the coal to the required quality specifications. This study forms part of US Department of Energy program "Engineering Development of Advanced Physical Fine Coal Cleaning for Premium Fuel Applications," (Contract No. DE-AC2292PC92208), under Task 11, Project Final Report.

The primary objective of the Department of Energy program is to develop the design base for prototype commercial advanced fine coal cleaning facilities capable of producing ultra-clean coals suitable for conversion to stable and highly loaded CWF. The fuels should contain less than $2 \mathrm{lb}$ ash/MBtu (860 grams ash/GJ) of HHV and preferably less than $1 \mathrm{lb}$ ash/MBtu (430 grams ash/GJ). The advanced fine coal cleaning technologies to be employed are advanced column froth flotation and selective agglomeration. It is further stipulated that operating conditions during the advanced cleaning process should recover not less than 80 percent of the carbon content (heating value) in the run-of-mine source coal. These goals for ultra-clean coal quality are to be met under the constraint that annualized coal production costs does not exceed $\$ 2.5 / \mathrm{MBtu}(\$ 2.37 / \mathrm{GJ})$, including the mine mouth cost of the raw coal. A further objective of the program is to determine the distribution of a selected suite of eleven toxic trace elements between product CWF and the refuse stream of the cleaning processes.

Laboratory, bench-scale and Process Development Unit (PDU) tests to evaluate advanced column flotation and selective agglomeration were completed earlier under this program with selected coal samples. A PDU with a capacity of $2 \mathrm{st} / \mathrm{h}$ was designed by Bechtel and installed at Amax R\&D, Golden, Colorado by Entech Global for process evaluation tests. The tests successfully demonstrated the capability of advanced column flotation as well as selective agglomeration to produce ultra-clean coal at specified levels of purity and recovery efficiency. Test results and the experience gained during the operation of the PDU have provided valuable insights into the processes studied.

Based on the design data obtained from the test work and a set of project design criteria, two sets of conceptual designs for commercial CWF production plants have been developed, one using column flotation and the other using selective agglomeration process. Using these designs, Capital as well as Operating and Maintenance (O\&M) cost estimates for the plants have been compiled. These estimates have then been used to derive the annualized cost of production of premium CWF on a commercial scale. Further, a series of sensitivity analysis have been completed to evaluate the effects of variations in selected cost components and process parameters on the overall economics of premium fuel production 
The rest of this report is arranged as follows. Study results and Conclusions \& Recommendations are provided under Section 3. The design criteria used in the development of conceptual designs for commercial CWF plants are included in Section 4. Descriptions of the conceptual designs based on column flotation and selective agglomeration technologies appear in Section 5 and 6 respectively. Capital and O\&M cost estimates as well as the production cost of CWF are presented in Sections 7 and 8 for the two technologies. The two sections also discuss cost sensitivity to variations in selected parameters. A list of Acronyms and Abbreviations is placed under Section 9. Details of capital cost estimates are placed in Appendices A and B. Calculations relating to the sensitivity analysis are under Appendices C and D for column flotation and selective agglomeration cases respectively. 


\section{Section 3}

\section{Conclusions and Recommendations}

Column Flotation and selective agglomeration test work with selected coals was completed earlier under the research program. The laboratory, bench-scale, and $2 \mathrm{st} / \mathrm{h}$ capacity Process Development Unit (PDU) tests successfully demonstrated the capability of column flotation as well as selective agglomeration to produce ultra-clean coal at specified levels of purity and recovery efficiency. Test results and the experience gained during the operation of the PDU have helped develop design bases for commercial plants.

Based on process design data obtained from the test work and a set of project design criteria, two sets of conceptual designs for commercial CWF production plants have been developed, one using column flotation and the other, selective agglomeration. Each design was for commercial plant with a capacity to produce 2.5 million st of premium CWF, containing $60 \%$ solids by weight (1.5 million st per year dry clean coal). Capital, O\&M cost estimates have been developed based on these conceptual designs leading to the cost of production of premium CWF on a commercial scale.

\subsection{COST OF PREMIUM CWF - COLUMN FLOTATION}

The estimated capital cost of the plant based on column flotation is $\$ 69.6$ million (First Quarter -1997). CWF production cost (without considering the cost of coal in the product) including capital charges is estimated at $\$ 0.91 / \mathrm{MBtu}$. Major elements of the cost are as follows:

\section{$\underline{\text { Cost Element }} \quad \underline{\text { \$MBtu }} \quad \underline{\%}$}

Capital charges and interest

$\begin{array}{llll}\text { on Working Capital } & 0.27 & 29.1 \\ \text { CWF additive, A-23 } & 0.23 & 25.6 \\ \text { Labor } & 0.13 & 14.6 \\ \text { Electric power } & 0.11 & 12.3 \\ \text { Flotation reagents } & & & \\ \text { \& Flocculant } & 0.07 & 7.5 \\ \text { Btu Loss } & 0.05 & 5.5 & \\ \text { Others } & \underline{0.05} & \underline{5.4} & \\ \text { Total Cost of CWF } & \underline{0.91} & \underline{100.0} & \text { Less cost of coal }\end{array}$

Including the cost of coal delivered to plant site at $\$ 1.24 / \mathrm{MBtu}$, the total cost of premium CWF comes to $\$ 2.15 / \mathrm{MBtu}(\$ 1.24+\$ 0.91)$.

The target set under the research program for the cost of production of premium CWF is $\$ 2.50 / \mathrm{MBtu}$ including the mine mouth cost of coal. The above mentioned cost of $\$ 2.15 / \mathrm{MBtu}$ includes a transportation cost of $0.20 \$ / \mathrm{MBtu}$ for the raw coal. Based on mine mouth coal cost, the estimated cost of production of premium CWF is $\$ 1.95 / \mathrm{MBtu}$ (\$2.15 less \$0.20) which is well below the targeted cost of production. 
Sensitivity Studies One of the major elements in the cost of production of CWF is the cost of A-23 additive dispersant. Use of the additive becomes necessary to meet the specified 60 percent solids loading of the product. If the solids loading could be reduced to 54 percent, the slurry could be produced without the use of this additive. In such an event the total cost of CWF would be reduced from $\$ 2.15 / \mathrm{MBtu}$ to $\$ 1.92$ representing a reduction of $\$ 0.23 / \mathrm{MBtu}$. With a reduced solids content of 54 percent, the HHV of premium fuel is lowered to $8100 \mathrm{Btu} / \mathrm{lb}$, a value below the target specification which calls for a minimum $\mathrm{HHV}$ of $8900 \mathrm{Btu} / \mathrm{lb}$. It is believed that for the user, the penalty for reduced $\mathrm{HHV}$ will be more than off-set by the reduction of $\$ 0.23 / \mathrm{MBtu}$ in fuel costs.

A series of sensitivity analysis have been performed to evaluate the sensitivity of the cost of production of CWF to variations in other selected cost components. In addition to capital cost and the cost of raw coal, the factor that could affect the production cost most significantly, as may be expected, is the annual production rate.

\subsection{COST OF PREMIUM CWF - SELECTIVE AGGLOMERATION}

The estimated capital cost of the plant based on selective agglomeration is $\$ 97.2$ million (First Quarter -1997). CWF production cost (without considering the cost of coal in the product) including capital charges is estimated at $\$ 1.18 / \mathrm{MBtu}$. Major cost elements are as follows:

\begin{tabular}{llll}
\multicolumn{1}{c}{ Cost Element } & $\underline{\$ / \mathrm{MBtu}}$ & $\underline{\%}$ \\
Capital charges and & & & \\
Interest on Working Capital & 0.37 & 31 \\
CWF additive, A-23 & 0.23 & 20 \\
Labor & 0.17 & 15 \\
Electric power & 0.15 & 13 & \\
Steam & 0.13 & 11 & \\
Others & $\underline{0.13}$ & $\underline{10}$ & Less coal cost \\
Total Cost of CWF & $\underline{1.18}$ & $\underline{100}$
\end{tabular}

Including the cost of coal delivered to plant site at $\$ 1.24 / \mathrm{MBtu}$, the total cost of producing premium $\mathrm{CWF}$ is estimated at $\$ 2.42 / \mathrm{MBtu}(\$ 1.24+\$ 1.18)$ for the selective agglomeration process.

The target set under the research program for the cost of production of premium CWF is $\$ 2.50 / \mathrm{MBtu}$ including the mine mouth cost of coal. The above mentioned cost of $\$ 2.42 / \mathrm{MBtu}$ includes a transportation cost of $0.20 \$ / \mathrm{MBtu}$ for the raw coal to the plant site. Based on mine mouth coal cost, the estimated cost of production of premium CWF is $\$ 2.22 / \mathrm{MBtu}(\$ 2.42$ less $\$ 0.20)$. This value is well below the targeted cost of production of $\$ 2.50 / \mathrm{MBtu}$ set for the research program based on mine mouth cost of coal. 
Sensitivity Studies A major elements in the cost of production of CWF is the cost of A23 additive dispersant. Use of the additive becomes necessary to meet the specified 60 percent solids loading of the product. If the solids loading could be reduced to 54 percent, the slurry could be produced without the use of this additive. In such an event the total cost of CWF would be reduced from $\$ 2.42 / \mathrm{MBtu}$ to $\$ 2.19$ representing a reduction of $\$ 0.23 / \mathrm{MBtu}$. A reduction in the solids content to 54 percent lowers the HHV of premium CWF to $8100 \mathrm{Btu} / \mathrm{lb}$, a value below the target specification of $8900 \mathrm{Btu} / \mathrm{lb}$. It is believed that the penalty for the reduced HHV will be more than off-set to the consumer by the reduction of $\$ 0.23 / \mathrm{MBtu}$ in fuel costs.

A series of sensitivity analysis are performed to evaluate the sensitivity of the cost of production of CWF to variations in other selected cost input parameters. In addition to capital cost and the cost of raw coal, the factor that could affect the production cost most significantly, as may be expected, is the annual production rate.

\subsection{RECOMMENDATIONS}

The estimated cost of commercial production of premium CWF using either column flotation or selective agglomeration is encouraging. Column flotation, in particular, is more promising. This process, in spite of its lower energy and weight recovery, is found more economical than selective agglomeration while offering a comparable quality product. Total processing cost with column flotation at $\$ 0.91 / \mathrm{MBtu}$ is significantly lower than the cost of $\$ 1.18 / \mathrm{MBtu}$ estimated for the plant using the selective agglomeration.

As found during CWF cost sensitivity analysis, one of the significant factors that could vitally affect production costs is the annual sustainable production rate. Product costs would escalate drastically if the annual production rate of 1.5 million st cannot be achieved in plants built according to conceptual designs presented herein. Two significant technical factors that could adversely affect production are: (a) reduced plant availability due to worse than anticipated plant operability or maintenance requirements (b) feed coal harder to grind than expected, which will reduce the grinding capacity and thus the plant out-put.

These technical uncertainties are best resolved by operating experience with a larger scale plant and for a longer term than was possible with the PDU phase of the program. It was noticed during the conceptual design stage that plants with a capacity of 1.5 million st/year of ultra-clean coal will need 12 parallel trains of commercial size flotation columns or ten parallel trains of commercial size equipment for the selective agglomeration plant. This would suggest installation of demonstration/production plant using a single train of commercial size equipment with a capacity of $125,000 \mathrm{st} / \mathrm{y}$.

Another issue of uncertainty is the acceptability of the product. Before long-term commitments could be made, all potential clients would need verification, by meaningful plant scale testing, of the suitability of premium CWF for their applications. A single 
train demonstration/production plant of the capacity suggested will enable production of adequate quantities of premium CWF for this purpose.

The demonstration/production plant is preferably built close to a coal mine so that costs associated with coal transportation, refuse disposal and rail car unloading facilities can be eliminated or minimized. 


\section{Section 4 \\ Commercial CWF Plant Design Criteria}

This section presents design criteria which have been used for the development of two conceptual designs for commercial premium CWF production plants. One of the designs uses advanced column flotation for cleaning the coal and the other selective agglomeration. Process design and equipment selection criteria specific to column flotation and selective agglomeration are addressed in Section 5 and Section 6 respectively.

\subsection{COAL FEED STOCK}

Several dozen coals from different regions of the US were evaluated and many were tested in the laboratory under Task 2 . The tests were designed to identify coals that could significantly benefit from advanced column flotation and/or selective agglomeration and produce economically ultra-clean coal to specifications. Coal characteristics tested included: (a) sulfur content and forms of sulfur occurrence (organic and mineral or pyritic) and (b) ash liberation characteristics. The latter determines to a large extent electric power requirements to prepare the coal by grinding ahead of the cleaning processes. Six coals were then selected for process research and development in bench scale. Finally, three coals were tested in the PDU. Based on these studies, the most appropriate coal feed stock for the commercial production of premium CWF is a bituminous high-volatile sulfur-compliance coal which also meets ash liberation requirements for advanced cleaning processes. Pre-washed Taggart (Upper Elkhorn No. 3), Elkhorn No. 3, and Sunnyside seam coals and the unwashed Hiawatha seam coal were found to fulfill these requirements during evaluations conducted earlier under this. Other coals, such as No. 2 Gas (Campbell Creek), are also likely to be suitable.

Feed Coal Sulfur Content Specifications for premium CWF call for a sulfur content below $0.6 \mathrm{lb} / \mathrm{MBtu}$, the limit for compliance coals. Physical coal cleaning processes like column flotation and selective agglomeration can only remove the pyritic form of sulfur in coal and not the organic form. A special effort was made to identify non-compliance raw coals with significantly high pyritic sulfur content but a low (below the limit for compliance coals) organic sulfur component. No such coal could be found. The noncompliance coals that were evaluated had consistently more than $0.6 \mathrm{lb}$ of sulfur per MBtu of organic sulfur. Thus it would appear that the feed stock to the commercial plant will most likely be a compliance coal to begin with.

Grinding Power Requirements Electric power required to grind the coal prior to cleaning is a major element in the cost of production of ultra-clean coals. Power consumption for grinding is affected largely by ash-mineral liberation characteristics of the coal and, to a lesser extent, its grindability. Grindability is often expressed in terms of the Hardgrove Grindability Index (HGI). A coal with unfavorable ash-mineral liberation characteristics contains ash disseminated in the coal mass as extremely fine particles. Such a coal will need ultra-fine grinding at an exorbitant power consumption to liberate 
ash minerals ahead of the cleaning step. Poor grindability further aggravates energy consumption.

The coals listed above (Taggart, Elkhorn \# 3, Sunnyside, Hiawatha) were found to be the most appropriate feed stocks after taking the relevant factors into consideration.

Significant characteristics of the design feed coal, which could be a blend of more than one coal, are:

\begin{tabular}{|l|l|l|}
\hline Proximate Analysis: & \multicolumn{2}{|l|}{} \\
\hline Ash & wt $\%$ & 7.0 \\
Volatile Matter & wt $\%$ & 30.0 \\
Fixed Carbon & wt $\%$ & 56.0 \\
Moisture-total & wt \% & 7.0 \\
& & \\
Inherent Moisture & wt \% & 2.0 \\
Surface Moisture & wt \% & 5.0 \\
Ash-dry basis & wt \% & 7.5 \\
Heating Value -as received basis & Btu/lb & 13,070 \\
Nominal Size & inch & 2 x 0 \\
Hardgrove Grindability Index & & 52 \\
\hline
\end{tabular}

\subsection{CWF SPECIFICATIONS}

The target specifications for the CWF (product) are given below:

\begin{tabular}{|l|l|l|}
\hline Ash-dry basis & wt $\%$ & $<2.8$ \\
Ash content & lb/MBtu & $<1.8$ \\
Sulfur-dry basis & wt $\%$ & $<0.88$ \\
Sulfur-dioxide emission potential & lb/MBtu & $<1.2$ \\
Sulfur & lb/MBtu & $<0.6$ \\
Solids loading -based on dry solids & wt $\%$ & $60-62$ \\
Slurry viscosity at $100 \mathrm{~s}^{-1}$ shear rate & cp. & $<500$ \\
Slurry viscosity at $1000 \mathrm{~s}^{-1}$ shear rate & cp. & $<1,000$ \\
Higher Heating value of CWF & Btu/lb & $8900-9,400$ \\
Maximum particle size & mesh & 100 \\
\hline
\end{tabular}

\subsection{ANNUAL CAPACITY OF THE PLANTS}

Conceptual designs and cost estimates are based on an annual out-put capacity 2.5 million st of CWF containing 60 percent by weight of dry solids. This quantity of CWF will require an annually production of 1.5 million st of ultra-clean coal on a dry basis. 


\subsection{PLANT LOCATION}

The plant is to be located near an industrial center like Cincinnati or Cleveland in the Ohio river valley. It is assumed that the plant site has adequate infra-structure normally available in industrial areas.

The infra-structure facilities include utility lines, highways and rail tracks close to the property. In addition, the selective agglomeration plant will be located near a power station which could supply low pressure steam to the plant. Availability of efficient rail links to the sites is essential to permit flexibility in coal procurement from different sources and in the shipment of the product. Roads, utility distribution lines and rail tracks within the battery limits are included in the cost estimates.

\subsection{PLANT OPERATING SCHEDULE}

The plants are designed to operate three 8-hour shifts a day and 19 shifts a week. Two shifts in each week are set aside for maintenance. In addition, an annual 2 week shut down is taken for major maintenance work. This schedule gives 7,600 operating hours in a year.

\subsection{COAL RECEIVING}

Coal is supplied to the plants in unit trains of open gondola cars from one or more mines. Facilities are provided to unload cars during winter months under freezing conditions. Unlike the rest of the plants, coal unloading is designed to operate 2-shifts a day and 5 days a week. The shorter schedule and higher unloading rates are selected to minimize detention of rail cars at plant sites. The cars are unloaded using a rotary car dumper at a rate of $2000 \mathrm{st} / \mathrm{h}$. The unloading section includes thawing sheds to heat frozen car loads. Rail tracks included within the battery limits are adequate to accept coal and product cars.

\subsection{STORAGE}

Facilities will store thirty thousand st of as received coal at the plant site. This level of on-site storage allows the production facilities to operate continuously at design rate for 5 days without any additional receipt of rail delivered coal. Silos have been selected as they represent environmentally the most acceptable method for large scale coal storage in the proximity of major settlements.

\subsection{CRUSHING AND GRINDING}

Raw coal is crushed and then ground to a nominal 100 mesh top size (D80= 325 mesh) for both column flotation and selective agglomeration plants. The coal is crushed to a top size of $1 / 2$ inch ahead of the ball mills used for grinding the coal. Wet closed circuit grinding has been adopted to reduce both grinding energy consumption and generation of super fines. Super fines are difficult to dewater, tend to increase slurry viscosity, and, for column flotation, difficult to clean. 


\subsection{COAL CLEANING PROCESSES}

Either column flotation or selective agglomeration are used to clean and enhance coal quality to the level specified for the premium CWF. Selective agglomeration includes recovery of the bridging liquid, heptane.

\subsection{CLEAN COAL DEWATERING, WATER CLARIFICATION AND TAILINGS HANDLING}

The circuits for clean coal and tailings dewatering and systems for water clarification use largely similar if not identical equipment for both column flotation and selective agglomeration plants.

Vacuum filters are used for filtering the clean coal. Tailings after thickening in a static thickener are dewatered using a continuous belt press.

\subsection{TAILINGS DISPOSAL}

The tailings after dewatering, the solid waste from the plant, are disposed off in a land fill by trucks. Depending upon site specific conditions, alternate and more economical disposal methods could be available

\subsection{CWF PREPARATION}

The plant is designed to produce highly loaded CWF with minimum water content. The slurry fuel must, at the same time, exhibit a viscosity low enough for easy pumping and handling. It is expected that the slurry viscosity must be below $500 \mathrm{cp}$. to be acceptable.

The highest solid loading achievable in a coal-water mixer without exceeding viscosity limits depends upon several variables. The most significant of these are: mass mean diameter of the particles, particle size distribution, particle shape, packing tendencies of the particles, type and quantity of additives and inherent coal moisture. It is well known that a 'bimodal' particle size distribution promotes high solid loading in a slurry. A bimodel particle size distribution is one with large concentrations of particles in the coarsest as well as the finest ends of the particle size distribution spectrum. Such a distribution helps pack the solids and thus improve solid loading without a significant increase in viscosity.

A series of slurry formulation tests were conducted with flotation and selective agglomeration concentrates during the program. Several tests were performed to evaluate benefits of modifying the size distribution and simulate a bimodal particle size distribution. A fine size fraction of the clean coal concentrates weighing up to 30 percent of the total was reground to sizes finer than 325 mesh and mixed back with the rest of the concentrates. The reformed concentrates with modified size distribution were slurried and tested in the laboratory to determine the improvement in the solid loading at the 
permitted level of viscosity. The tests produced less than satisfactory results. Blending of even large amounts of reground fines (30 percent) with the concentrates did not improve the solid loading with Taggart and Elkhorn No. 3 CWF. With Hiawatha and Sunnyside coals this procedure brought about only a marginal improvement, from 59-60 percent solids to 61 to 63 percent (Page 13, Subtask 6.4 CWF Formulation StudiesTopical-Report).

Further, duplicating this procedure for size consist modification on an industrial scale will be complicated. It would involve, (a) an operation to separate a fine coal fraction from the concentrate slurry stream, (b) partial dewatering of the stream so separated for additional regrinding, (c) regrinding, and (d) mixing the ground product with unground concentrates. These steps entail significant capital and operating costs. Considering the poor benefits seen with laboratory scale testing, it is considered that size consist modification will not be economically viable. No provision has therefore been made in the commercial plant designs for size consist modification. Consequently, the specification for solid loading for CWF have been reduced and set at 60 percent which was found to be achievable with the use of dispersant (A-23) additives alone.

The solids in the highly loaded CWF tend to settle out. The slurry has to be modified if it has to have adequate stability for long duration storage and transportation. One procedure would be to add a stabilizer additive such as Flocon. The additive is relatively expensive. At the required dosage of approximately $800 \mathrm{ppm}$ of the slurry and a price of $\$ 3.50$ per pound, the cost of the stabilizer alone is expected to be around $\$ 8$ per ton of solids in the CWF or $\$ 0.27$ per MBtu. Therefore the base design does not include stabilizers.

\subsection{CWF STORAGE AND LOADING}

Storage facilities for the product at the plant site are provided in the form of agitated tanks with a total capacity equivalent to 2 days of production.

CWF is shipped to customers in RR tank cars. Alternately, the product may be sent to customers from the storage tanks by pipeline. 


\section{Section 5}

\section{Conceptual Design of CWF Plant - Column Flotation}

A conceptual design for a commercial premium CWF production plant based on column flotation technology is presented in this section. It includes a discussion of the process design criteria and a description of the integrated facility.

\subsection{Process Design Criteria-Column Flotation}

Process design and equipment selection criteria used in the conceptual design are summarized and presented in Table 5.1.1.

With the design coal, it is expected that column flotation will achieve a heating value recovery of over 96 percent while producing specification quality clean coal. A clean coal weight recovery of approximately 90 percent will also be attained. As noted in Section 4, the plant operates 3 shifts a day and 19 shifts a week. However, there is an annual shut down for two weeks for major maintenance work. Based on this schedule, the weight recovery, and an availability of 94 percent of scheduled operating time, a design input capacity of $233 \mathrm{st} / \mathrm{h}$ (dry basis) has been calculated to produce 1.5 million st of clean coal per year (on a dry basis). If the availability is calculated on the basis of 8,760 hours (365 $\mathrm{x} 24)$ in a year, the selected hourly design capacity reflects an availability of 81 percent. This level of availability is considered achievable with adequate complement of standby equipment at critical locations of the plant.

Significant process and equipment design parameters such as energy for grinding, solids concentration in the flotation feed, the number and size of columns, consumption of compressed air and reagents, wash water usage, and tailings recirculation are shown in Table 5.1.1. The data are based on laboratory, bench-scale, and PDU testing.

Table 5.1.1 also provides details of process and equipment design criteria for clean coal dewatering, water clarification, tailings dewatering and handling, CWF preparation, and loading sections of the plant.

\subsection{Facility DESCRIPTION}

The commercial column flotation based CWF plant consists of the following sections:

- Raw Coal Handling - Plant 100

- $\quad$ Crushing and Grinding - Plant 200

- Column Flotation - Plant 300

- Clean Coal Dewatering - Plant 400

- Water Clarification and Tailings Handling - Plant 500

- $\quad$ CWF Preparation and Loading - Plant 600

A list of major equipment appears under Table 5.2.1. 


\subsubsection{Raw Coal Handling - Plant 100}

A process flow diagram for the raw coal handling section, Plant 100, is presented in Figure 5.1. Feed coal, crushed to a top size of 2 inch, is delivered to the CWF plant in RR cars. The cars are unloaded using a car dumper. The rail car unloading system includes thawing sheds for heating the cars during the winter months when freezing conditions could be encountered. A shunting locomotive is used to position the cars over the dumper. The cars are dumped, one car at a time, into a 200 ton dump hopper. A bar grid located at the top of the dump hopper prevents large lumps of frozen coal from entering the hopper. A frozen coal crusher (lump breaker) is used to break such lumps of coal over the grid.

Two variable capacity belt feeders located below the dump hopper deliver the coal to a raw coal conveyor which transports and elevates the coal to the top of the coal silos.

The raw coal conveyor working with two silo feed conveyors fills three raw coal concrete silos. Each silo has a capacity of 10,000 st.

The raw coal handling section is rated for a capacity of $2000 \mathrm{st} / \mathrm{h}$. It includes a comprehensive dust collection system to control emission of dust during coal dumping and conveying operations.

\subsubsection{Crushing and Grinding - Plant 200}

Figure 5.2 represents a process flow diagram for this plant section. A material balance is also shown in the figure.

This section of the plant includes two parallel and identical trains to crush and grind the coal ahead of flotation. Two variable speed belt feeders are provided below each of the coal silos for withdrawal of coal. Two crusher feed conveyors receive coal from the belt feeders. The conveyors deliver the coal to two hammer mill type crushers. The crushers are designed to crush the coal to a top size of $1 / 2 \mathrm{inch}$. Tramp iron magnets are included for the protection of the hammer mills. Crushed coal from the hammer mills is delivered to the ball mills by two ball mill feed conveyors. Each conveyor serves a grinding train.

Each grinding system includes a 4000 HP ball mill served by a set of three cyclone clusters for closed circuit operation. Each cyclone cluster has multiple cyclones. Coal is ground in the mills with water. The discharge slurry from each ball mill is diluted and pumped to the cyclone clusters. A distributor is used to distribute the flow equally among the cyclone clusters. Partially ground material exiting the cyclone apex (cyclone underflow) is returned to the mills for further grinding.

Cyclone overflow represents the finish ground slurry. It is sluiced to the flotation section in Plant 300. 


\subsubsection{Column Flotation - Plant 300}

Figure 5.3 presents a process flow diagram and a material balance for the column flotation section, Plant 300. The following description addresses one of two parallel and identical trains of equipment included in this section.

Ground slurry from the crushing and grinding plant (Plant 200) is received in a flotation feed sump provided with a mixer (agitator). Measured amount of water is added in the sump to ensure a constant pre-set solids content in the slurry fed to the flotation columns. There are six flotation columns in a train, a total of twelve in the plant. Each flotation column has a dedicated slurry feed pump. It is complete with dedicated reagent feeders, a tailings recirculation pump, a static air-slurry mixer, and a froth launder. A common air compressor provides air to six flotation columns. Froth from each flotation train (6 flotation columns) is collected in a clean coal sump, generously sized to accommodate and break the froth. Clean coal slurry from the sump is pumped to a slurry distributor which is included in Plant 400. All clean coal pumps are provided with installed spares of equal capacity.

\subsubsection{Clean Coal Dewatering - Plant 400}

Figure 5.4 shows a process flow diagram and a material balance for this plant section.

The clean coal dewatering section consists of two identical trains like the column flotation section (Plant 300). Each train is provided with six identical and parallel vacuum filtration lines. Clean coal slurry is dewatered and a filter cake with a surface moisture content of approximately 35 percent is produced. Filter cake from each set of six filters is collected by a dewatered coal conveyor. The two dewatered coal conveyors deliver the coal to two coal- additive mixers provided under Plant 600.

The water separated by the vacuum filters, the filtrate, may contain some solids. It is therefore recirculated through the flotation plant. It is pumped to the flotation feed sumps in Plant 300. All pumps in this section (Plant 400) are also provided with installed spares.

\subsubsection{Water Clarification and Tailings Handling - Plant 500}

Figure 5.5 presents a process flow diagram and a material balance for this plant section.

Tailings from flotation columns are collected in a thickener. The tailings solids are thickened and the water is clarified with the addition of measured amounts of flocculants to the feed slurry. The thick underflow from the thickener is pumped to a tailings filter sump. Additional amounts of flocculants are mixed with the slurry in the filter sump to facilitate filtering. A continuous Andritz type belt filter is used to dewater the tailings. The filtered tailings are collected by a tailings conveyor and conveyed to a storage pile under a shed. The tailings are loaded into trucks using front-end loaders for transport and 
disposal at a landfill. Clarified water from the thickener, the thickener overflow, is recirculated to the CWF preparation, flotation and grinding sections of the facility.

\subsubsection{CWF Preparation and Loading - Plant 600}

A process flow diagram and a material balance for this plant section is shown in Figure 5.6. This plant section also comprises two parallel and identical trains.

Dewatered flotation concentrates from the vacuum filters (the filter cake) is fed to two coal-additive mixers (one on each train). Here the cake is mixed intensely with the dispersant additive A-23 to obtain a good dispersal of the additive. The mixture is then fed to slurry mix tanks (one in each train) where measured amounts of water is added to obtain the desired solids content in the prepared CWF. From the slurry mix tanks, the CWF is pumped to storage tanks.

A total of four storage tanks are included with adequate capacity to hold a two day production of CWF. From the storage tanks, the CWF is pumped into RR tank cars. Alternately, the slurry fuel in the storage tanks may be pumped to nearby customers through pipe lines installed by others. 
Table 5.1.1

COMMERCIAL CWF PLANT - COLUMN FLOTATION

Process Design Criteria

I COLUMN FLOTATION PERFORMANCE

Heating value (HHV) recovery

Feed ash content- dry basis

Weight recovery

Feed HHV- dry basis

Product HHV-dry basis

Product ash per MBtu of HHV

Product ash- dry basis

II OPERATING SCHEDULE

Hours per shift

Shifts per day

Days per week

Scheduled maintenance shifts per week

Scheduled operating shifts per 7 day week

Scheduled operating weeks per year

Scheduled operating hours per year

III DESIGN HOURLY FEED RATE TO FLOTATION

Annual output required - dry basis

Average output per operating hour-dry basis

Plant availability based on scheduled operating hours.

Design output capacity-dry basis

Design weight recovery

Plant design input capacity-dry basis

Inherent moisture

Plant design input capacity-surface dry basis

Plant availability based on $24 \mathrm{~h} /$ day and $365 \mathrm{~d} / \mathrm{y}$

IV FLOTATION FEED SLURRY PREPARATION

Grinding circuit configuration

Ground product - nominal, $100 \%$ passing

Size (D80)

Size of coal feed to grinding mills

Specific power for grinding

Flotation feed solids content

\section{FLOTATION COLUMNS}

Flotation feed sump -retention time

Design clean coal flow rate-surface dry basis

Specific froth load at the column

Column overflow surface area required

Selected diameter of column (largest available)

Overflow area available per column

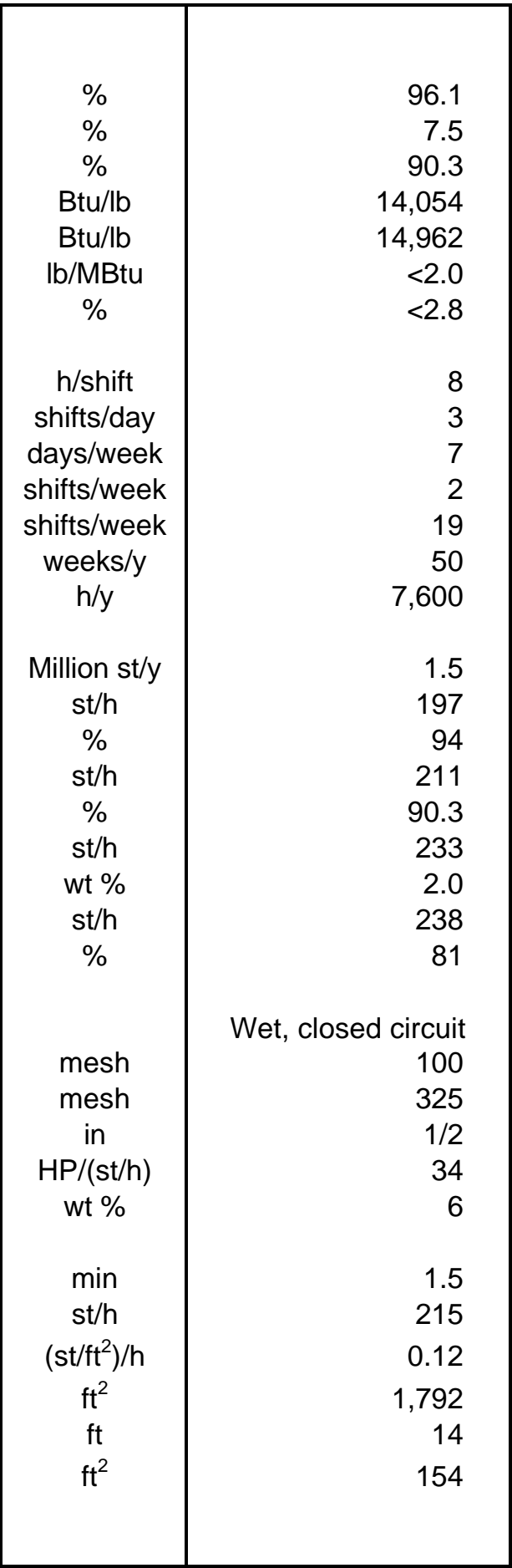


Table 5.1.1 (continued)

COMMERCIAL CWF PLANT - COLUMN FLOTATION

Process Design Criteria

V FLOTATION COLUMNS (Continued)

No of columns required

Specific wash water usage- based on flotation feed

Bias Ratio

Tailings recirculation at column-based on flotation feed

Solids content of froth

Air requirement

Frother dosage

Collector dosage

VI CLEAN COAL DEWATERING

Equipment type

Filter cake moisture content

VII WATER CLARIFICATION AND TAILINGS DEWATERING

Equipment type

Tailings thickener -Specific thickening rate

Thickener under flow -surface moisture content

Tailings filter- type

Moisture content of dewatered tailings, filter cake

VIII CWF PREPARATION AND LOADING

Additives:

Dispersant Additive

Dispersant (Solid) dosage per dry ton of coal

Water content of solution

Stabilizer

Storage capacity for CWF at site at normal production rate

Type of storage

Rail car loading rate:

CWF

Coal on a dry basis

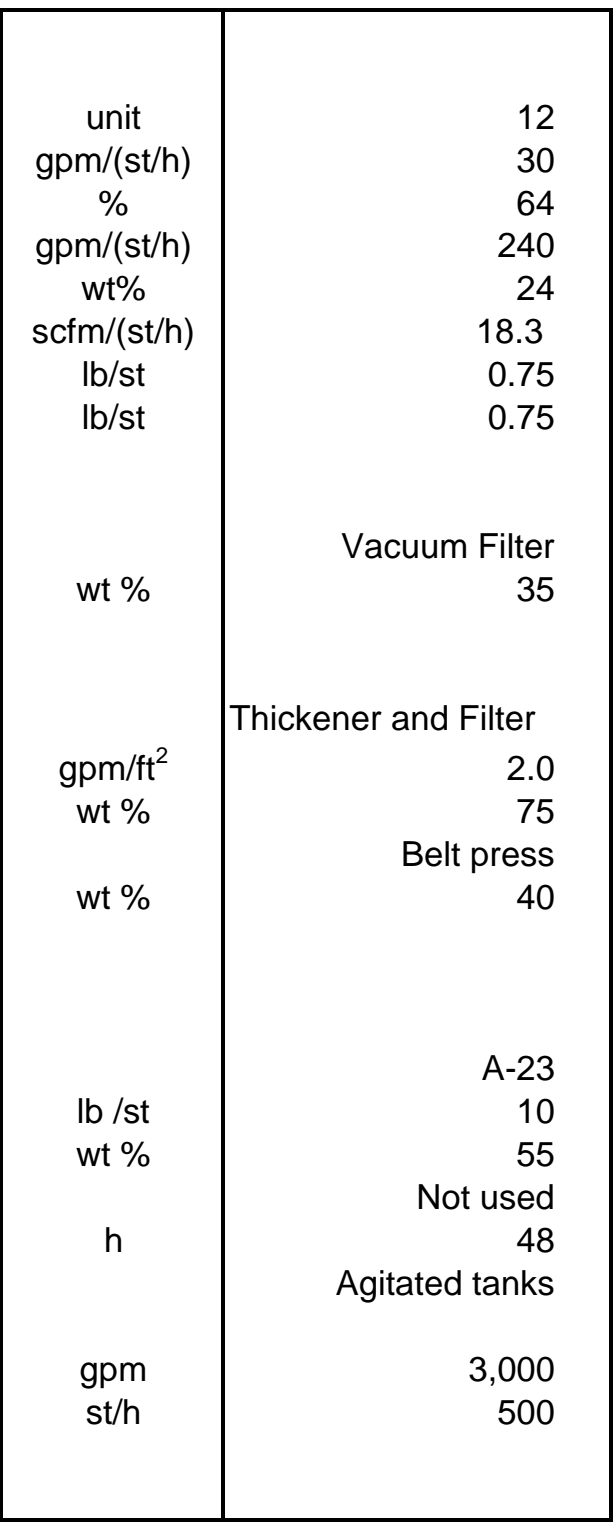


Table 5.2.1

COMMERCIAL CWF PLANT- COLUMN FLOTATION

Major Equipment List

\begin{tabular}{|c|c|c|c|c|c|c|}
\hline & $\begin{array}{c}\text { Equipment } \\
\text { I.D }\end{array}$ & Qty & Title & Description & $\begin{array}{l}\text { Power- } \\
\text { ea. } \\
\text { HP }\end{array}$ & $\begin{array}{c}\text { Total } \\
\text { installed } \\
\text { HP }\end{array}$ \\
\hline 100 & BN-01 thru 03 & 3 & $\begin{array}{l}\text { Raw coal silos, No. 1, } 2 \text {, } \\
\text { and } 3\end{array}$ & $10,000 \mathrm{st}$ (ea.), $70 \mathrm{ft}$ dia $\times 150 \mathrm{ft} \mathrm{ht}$ & & \\
\hline 100 & CV-01 & 1 & Raw coal conveyor & $\begin{array}{l}2000 \mathrm{st} / \mathrm{h}, 60 \mathrm{in} \text { wide } \times 750 \mathrm{ft} \text { lg., } \\
220 \mathrm{ft} \text { lift, } 500 \mathrm{fpm} \text {, with belt scale }\end{array}$ & 600 & 600 \\
\hline 100 & CV-02 & 1 & Silo feed conveyor No. 1 & $\begin{array}{l}2000 \mathrm{st} / \mathrm{h}, 60 \text { in wide } \times 80 \mathrm{ft} \text { lg., } \\
10 \mathrm{ft} \text { lift, } 500 \mathrm{fpm}\end{array}$ & 50 & 50 \\
\hline 100 & CV-03 & 1 & Silo feed conveyor No. 2 & $\begin{array}{l}2000 \mathrm{st} / \mathrm{h}, 60 \text { in wide } \times 80 \mathrm{ft} \text { lg., } \\
\text { no lift, } 500 \mathrm{fpm}\end{array}$ & 50 & 50 \\
\hline 100 & DC-01 thru 03 & 3 & $\begin{array}{l}\text { Silo top dust collector with } \\
\text { fan }\end{array}$ & $\begin{array}{l}7000 \mathrm{cfm} \text {, filtering area } 1200 \text { sq. } \mathrm{ft} \\
\text { including fan }\end{array}$ & 40 & 120 \\
\hline 100 & RR-01 & Lot & Rail car unloading system & $\begin{array}{l}\text { For } 2000 \text { st/h unloading rate } \\
\text { including rotary car dumper, } \\
\text { shunting locomotive, } 200 \text { st dump } \\
\text { hopper, grizzly, frozen coal } \\
\text { crusher, thawing shed, dust } \\
\text { collection, raw coal conveyor } \\
\text { tunnel, sump pump, feeders, rail } \\
\text { track of } 2 \text { miles }\end{array}$ & 700 & 700 \\
\hline 100 & ST-01 \& 02 & 2 & Motorized gate & Capacity- 2000 st/h & 10 & 20 \\
\hline 200 & AG-01 \& 02 & 2 & $\begin{array}{l}\text { Cyclone feed pump sump } \\
\text { mixers }\end{array}$ & For Cyclone feed sump & 15 & 30 \\
\hline 200 & $\mathrm{CN}-01$ & 1 & Mill house crane & 30 t main hook, 5 ton aux & 75 & 75 \\
\hline 200 & CR-01 \& 02 & 2 & Hammer mill crusher & $\begin{array}{l}125 \mathrm{st} / \mathrm{h} \text {, feed size } 2 " \text { × } 0 \text { and } \\
\text { product } 1 / 2 " \text { × } 0\end{array}$ & 300 & 600 \\
\hline 200 & CS-01 thru 06 & 6 & Cyclone cluster & $\begin{array}{l}\text { Flow } 1200 \mathrm{gpm} / \text { cluster-20 no. of } 4 \\
\text { in cyclones per cluster }\end{array}$ & & \\
\hline 200 & CV-10 \& 11 & 2 & Crusher feed conveyor & $\begin{array}{l}125 \mathrm{st} / \mathrm{h}, 30 \mathrm{in} \text { wide } \times 300 \mathrm{ft} \text { lg., } 25 \\
\mathrm{ft} \text { lift, } 350 \mathrm{fpm} \text {, with belt scale }\end{array}$ & 15 & 30 \\
\hline 200 & CV-12 \& 13 & 2 & Ball mill feed conveyor & $\begin{array}{l}125 \mathrm{st} / \mathrm{h}, 30 \mathrm{in} \text { wide } \times 100 \mathrm{ft} \text { lg., } 25 \\
\mathrm{ft} \text { lift, } 350 \mathrm{fpm}\end{array}$ & 15 & 30 \\
\hline 200 & DC-10 \& 11 & 2 & $\begin{array}{l}\text { Crusher house dust } \\
\text { collector with fan }\end{array}$ & & 50 & 100 \\
\hline 200 & FE-01 thru 06 & 6 & Reclaim feeder & $\begin{array}{l}125 \mathrm{st} / \mathrm{h}, 36 \text { in wide } x 40 \mathrm{ft} \text { lg.,75 } \\
\mathrm{fpm} \text {, (max.) variable speed drive }\end{array}$ & 10 & 60 \\
\hline 200 & MA-01 \& 02 & 2 & Tramp iron magnet & 125 st $/ \mathrm{h}, 36$ in belt & 10 & 20 \\
\hline 200 & ML-01 \& 02 & 2 & Ball mill & $125 \mathrm{st} / \mathrm{h}, 14.5 \mathrm{ft}$ dia $\times 29 \mathrm{ft}$ & 4000 & 8000 \\
\hline 200 & PP-01 thru 04 & 4 & Cyclone feed pump & $\begin{array}{l}\text { Horizontal slurry pump, flow } 3500 \\
\text { gpm, sp gr } 1.2 \text {, TDH } 130 \mathrm{ft}, 2 \\
\text { operating and } 2 \text { spare }\end{array}$ & 225 & 900 \\
\hline
\end{tabular}


Table 5.2.1

COMMERCIAL CWF PLANT- COLUMN FLOTATION

Major Equipment List (continued)

\begin{tabular}{|c|c|c|c|c|c|c|}
\hline & $\begin{array}{l}\text { Equipment } \\
\text { I.D }\end{array}$ & Qty & Title & Description & $\begin{array}{l}\text { Power- } \\
\text { ea. } \\
\text { HP }\end{array}$ & $\begin{array}{c}\text { Total } \\
\text { installed } \\
\text { HP }\end{array}$ \\
\hline 200 & ST-03 thru 8 & 6 & Motorized gate & Capacity- 125 st/h & 5 & 30 \\
\hline 200 & ST-10 \& 11 & 2 & Cyclone feed sump & $\begin{array}{l}7000 \text { gal capacity ( } 2 \text { min.) }-14 \mathrm{ft} \text { dia } \\
\times 15 \mathrm{ft} \text { ht, conical }\end{array}$ & & \\
\hline 200 & ZM-01 \& 02 & 2 & Distributor & 3 way-3500 gpm & 5 & 10 \\
\hline 300 & AG-03 \& 04 & 2 & $\begin{array}{l}\text { Flotation feed sump } \\
\text { mixer }\end{array}$ & & 30 & 60 \\
\hline 300 & CP-01 \& 02 & 2 & Air compressor & $\begin{array}{l}2250 \text { SCFM, } 125 \text { psig with air } \\
\text { receiver }\end{array}$ & 400 & 800 \\
\hline 300 & FT-01 thru 12 & 12 & Column flotation unit & $14 \mathrm{ft}$ dia, Micro cell or equal & & \\
\hline 300 & PP-05 thru 16 & 12 & Flotation feed pump & $\begin{array}{l}\text { Horizontal slurry pump, flow } 1100 \\
\text { gpm, sp gr } 1.02, \text { TDH } 65 \mathrm{ft}\end{array}$ & 30 & 360 \\
\hline 300 & PP-17 thru 28 & 12 & Recirculation pump & $\begin{array}{l}\text { Horizontal slurry pump, flow } 5,000 \\
\text { gpm, sp gr } 1.02, \mathrm{TDH} 65 \mathrm{ft}(14 \mathrm{x} \\
12 \text { Ash) }\end{array}$ & 150 & 1800 \\
\hline 300 & PP-29 thru 32 & 4 & Clean coal pump & $\begin{array}{l}\text { Horizontal slurry pump, flow } 2200 \\
\text { gpm, sp gr } 1.02, \text { TDH } 65 \mathrm{ft}(6 \times 5 \\
\text { Ash) }\end{array}$ & 60 & 240 \\
\hline 300 & PP-33 thru 44 & 12 & Frother dosing pump & $\begin{array}{l}\text { Variable speed peristaltic pump } \\
\text { (Omega FPU258 or equal) }\end{array}$ & 0.25 & 3 \\
\hline 300 & PP-45 thru 56 & 12 & Collector dosing pump & $\begin{array}{l}\text { Variable speed peristaltic pump } \\
\text { (Omega FPU258 or equal) }\end{array}$ & 0.25 & 3 \\
\hline 300 & ST-12 \& 13 & 2 & Flotation feed sump & $\begin{array}{l}17500 \text { gal capacity (2.3 min.)-14 ft } \\
\text { dia x } 16 \mathrm{ft} \text { (Cylindrical) }\end{array}$ & & \\
\hline 300 & ST-16 \& 17 & 2 & Clean coal sump & $\begin{array}{l}17500 \text { gal capacity (5 min.-froth } \\
\text { factor } 3 \text { )- } 14 \mathrm{ft} \text { dia x } 16 \mathrm{ft} \mathrm{ht} \\
\text { Cylindrical }\end{array}$ & & \\
\hline 300 & ST-20 \& 21 & 2 & Frother storage drum & $\begin{array}{l}\text { At } 1.5 \mathrm{lb} / \mathrm{st}, 200 \mathrm{~h}, 460 \mathrm{ft} 3,6.7 \mathrm{ft} \\
\text { dia, } 12 \mathrm{ft} \text { long, } 3 \mathrm{st} \text { wt each }\end{array}$ & & \\
\hline 300 & ST-22 \& 23 & 2 & Collector storage drum & $\begin{array}{l}\text { At } 1.5 \mathrm{lb} / \mathrm{st}, 200 \mathrm{~h}, 460 \mathrm{ft} 3,6.7 \mathrm{ft} \\
\text { dia, } 12 \mathrm{ft} \text { long, } 3 \mathrm{st} \text { wt each }\end{array}$ & & \\
\hline 400 & CV-15 & 2 & Coal solid conveyor & $\begin{array}{l}\text { Capacity } 130 \mathrm{st} / \mathrm{h}-24 \text { in wide, } 125 \\
\mathrm{st} / \mathrm{h}, 30 \mathrm{ft} \text { lift, }\end{array}$ & 5 & 10 \\
\hline 400 & FT-10 thru 15 & 6 & Filtration systems & $\begin{array}{l}\text { Capacity } 40 \text { st } / \mathrm{h} \text { - vacuum filter } \\
\text { systems }\end{array}$ & 700 & 4200 \\
\hline 400 & PP-62 \& 65 & 4 & Filtrate pump & $\begin{array}{l}\text { Flow } 2500 \mathrm{gpm} \text {, TDH } 30 \mathrm{ft} \text {, 2- } \\
\text { Operating and 2- Spare }\end{array}$ & 30 & 120 \\
\hline 400 & ST-26 \& 27 & 2 & Filtrate sump & Capacity- 5000 gal & & \\
\hline 400 & ZM-05 \& 06 & 2 & Slurry distributor & Capacity-3000 gpm & 10 & 20 \\
\hline 500 & AG-09 & 1 & $\begin{array}{l}\text { Tailings filter sump } \\
\text { agitator }\end{array}$ & Capacity of sump - $1000 \mathrm{gal}$ & 10 & 10 \\
\hline
\end{tabular}


Table 5.2.1

COMMERCIAL CWF PLANT- COLUMN FLOTATION

Major Equipment List (continued)

\begin{tabular}{|c|c|c|c|c|c|c|}
\hline & $\begin{array}{l}\text { Equipment } \\
\text { I.D }\end{array}$ & Qty & Title & Description & $\begin{array}{l}\text { Power- } \\
\text { ea. } \\
\text { HP }\end{array}$ & $\begin{array}{c}\text { Total } \\
\text { installed } \\
\text { HP }\end{array}$ \\
\hline 500 & BN-04 & 1 & Tailings load-out shed & Capacity- $100 \mathrm{st}$ & & \\
\hline 500 & CV-16 & 1 & Tailings conveyor & Capacity - 50 st/h, 24 in x $100 \mathrm{ft}$ & 5 & 5 \\
\hline 500 & FL-01 & 1 & Tailings filter & Capacity-30st/h, 3,5 m wide & 22 & 22 \\
\hline 500 & PP-70 \& 71 & 2 & $\begin{array}{l}\text { Thickener underflow } \\
\text { pump }\end{array}$ & $\begin{array}{l}\text { Horizontal slurry- capacity } 500 \\
\text { gpm, } 50 \mathrm{ft} \text { head, sp gr 1.07. } \\
\text { Operating, } 1 \text { - Spare }\end{array}$ & 15 & 30 \\
\hline 500 & PP-72 thru 74 & 3 & Clarified water pump & $\begin{array}{l}\text { Horizontal water- capacity } 10,000 \\
\text { gpm, } 35 \mathrm{ft} \text { head, sp gr } 1.0,2- \\
\text { Operating, } 1 \text { - Spare }\end{array}$ & 125 & 375 \\
\hline 500 & PP-75 \& 76 & 2 & Tailings filter feed pump & $\begin{array}{l}\text { Capacity } 420 \mathrm{gpm}, 30 \mathrm{ft} \text { head, sp } \\
\text { gr 1.07. 1- Operating, } 1 \text { - Spare }\end{array}$ & 15 & 30 \\
\hline 500 & ST-30 & 1 & Tailings filter feed sump & Capacity 1000 gal & & \\
\hline 500 & TK-01 & 1 & Tailings thickener tank & $\begin{array}{l}120 \mathrm{ft} \text { diameter thickener tank with } \\
\text { tunnel (concrete) }\end{array}$ & & \\
\hline 500 & TK-02 & 1 & Thickener overflow tank & Capacity 60,000 gal (concrete) & & \\
\hline 500 & TM-01 & 1 & Thickener mechanism & $\begin{array}{l}120 \mathrm{ft} \text { dia thickener mechanism } \\
\text { with controls }\end{array}$ & 20 & 20 \\
\hline 500 & ZM-08 & 1 & $\begin{array}{l}\text { Flocculant storage, mixing } \\
\text { and dosing system }\end{array}$ & & 5 & 5 \\
\hline 600 & AG-10 \& 11 & 2 & Coal additive mixer & Retention 5 min & 40 & 80 \\
\hline 600 & AG-12 \& 13 & 2 & $\begin{array}{l}\text { Slurry mixing tank } \\
\text { agitator }\end{array}$ & For tanks $600-\mathrm{ST}-31 \& 32$ & 40 & 80 \\
\hline 600 & AG-14 thru 17 & 4 & $\begin{array}{l}\text { Slurry storage tank } \\
\text { agitator }\end{array}$ & For tanks $600-\mathrm{ST}-33$ thru 36 & 75 & 300 \\
\hline 600 & PP-78 \& 79 & 2 & CWF pump & $\begin{array}{l}\text { Horizontal slurry- Capacity-1500 } \\
\text { gpm, } 60 \mathrm{ft} \text { head, sp gr } 1.17\end{array}$ & 60 & 120 \\
\hline 600 & PP-80 thru 83 & 4 & Slurry loading pump & $\begin{array}{l}\text { Horizontal slurry- Capacity-dry } \\
\text { solids } 500 \mathrm{st} / \mathrm{h} \text { - slurry } 3,000 \mathrm{gpm} \text {, } \\
60 \mathrm{ft} \text { head, sp gr 1.17, 4-Operating } \\
\text { and 4- spare }\end{array}$ & 100 & 400 \\
\hline 600 & ST-31 \& 32 & 2 & Slurry mixing tank & 10 min. each. Volume: & & \\
\hline 600 & ST-33 thru 36 & 4 & Slurry fuel storage tank & $\begin{array}{l}0.85 \text { million gal- } 55 \mathrm{ft} \text { dia and } 53 \mathrm{ft} \\
\text { high- total } 48 \mathrm{hr} \text {. }\end{array}$ & & \\
\hline 600 & ZM-10 \& 11 & 2 & $\begin{array}{l}\text { Flocculant storage, } \\
\text { mixing and dosing system }\end{array}$ & & 10 & 20 \\
\hline \multicolumn{6}{|c|}{ TOTAL MAJOR EQUIPMENT } & 20,538 \\
\hline
\end{tabular}




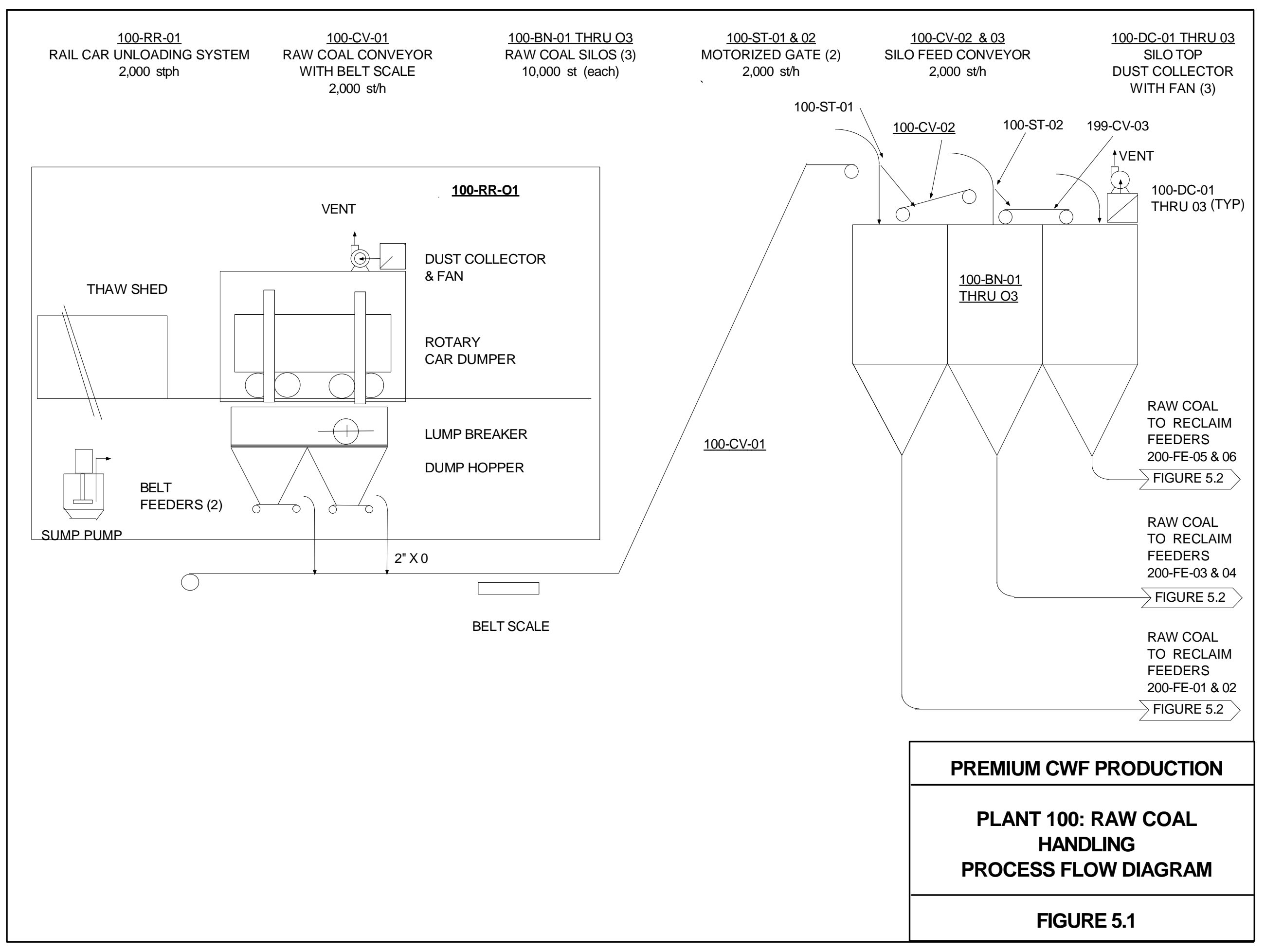




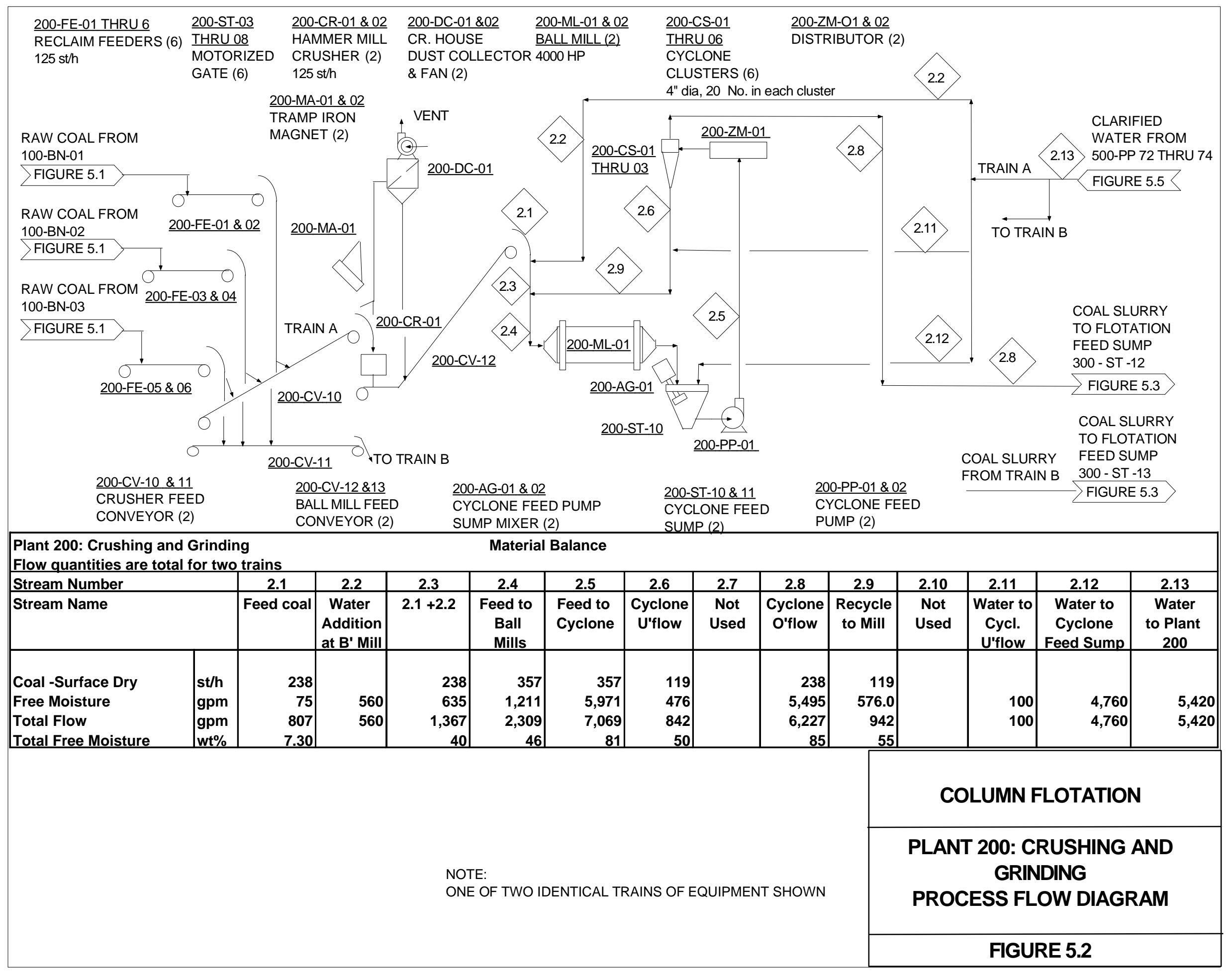




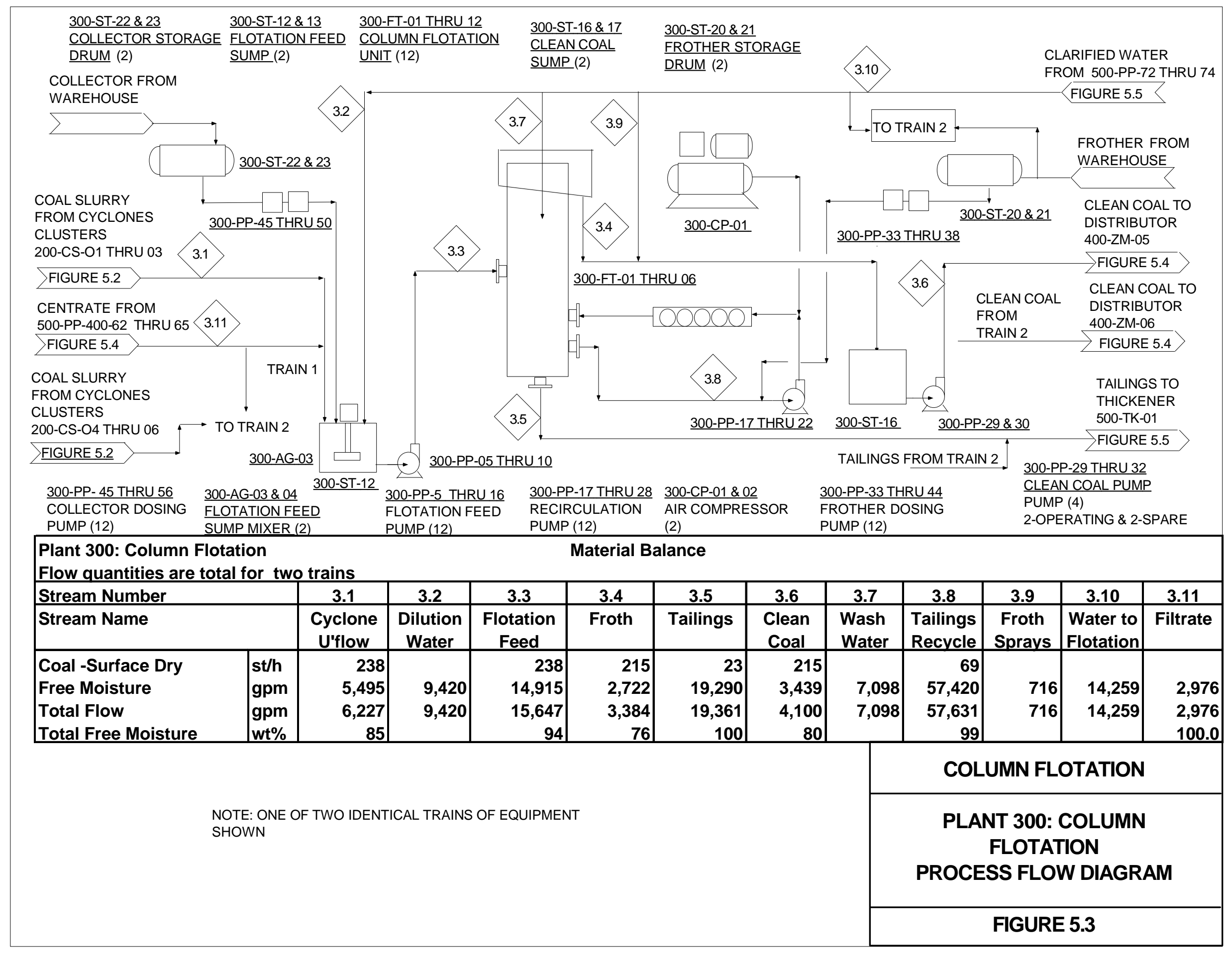




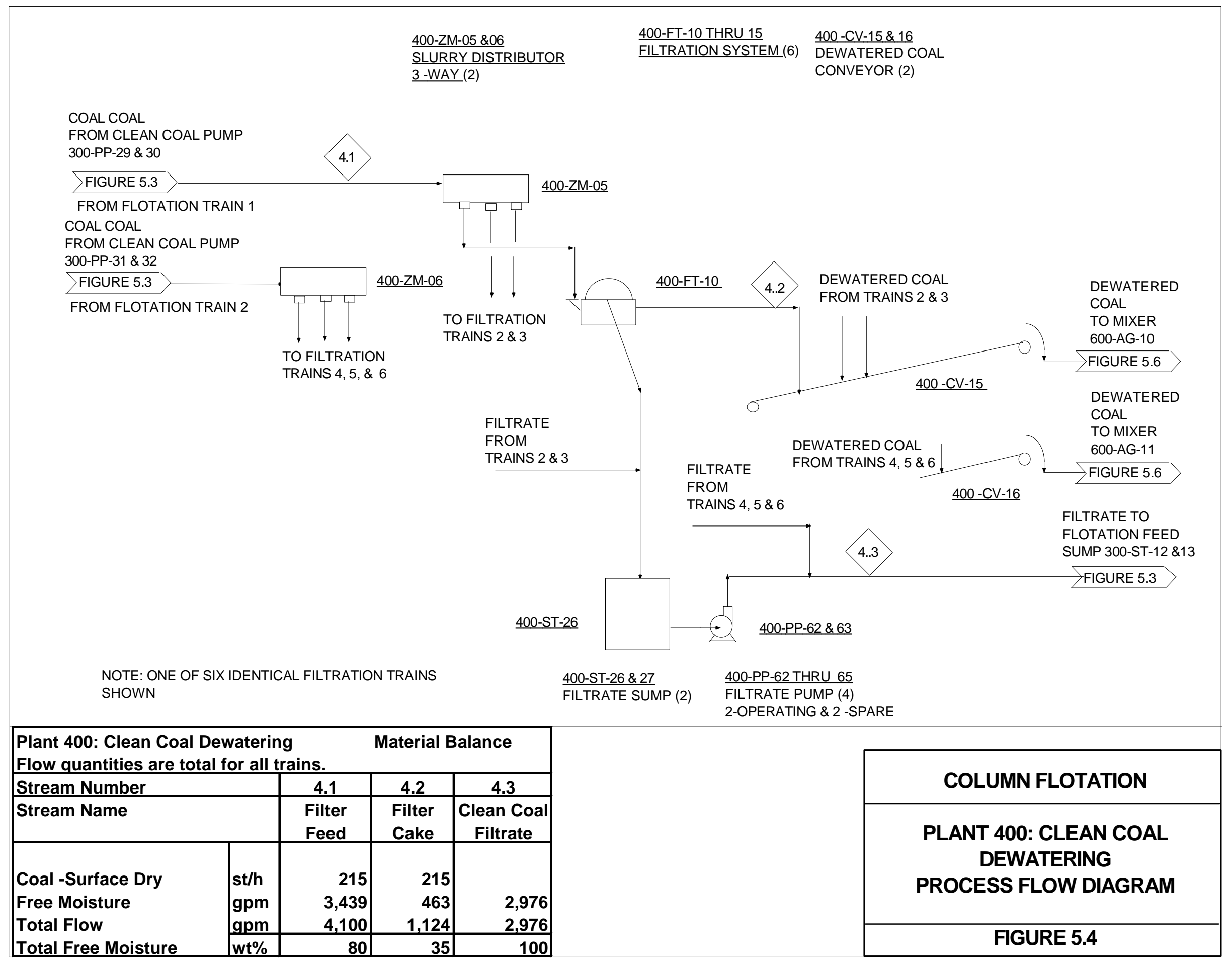




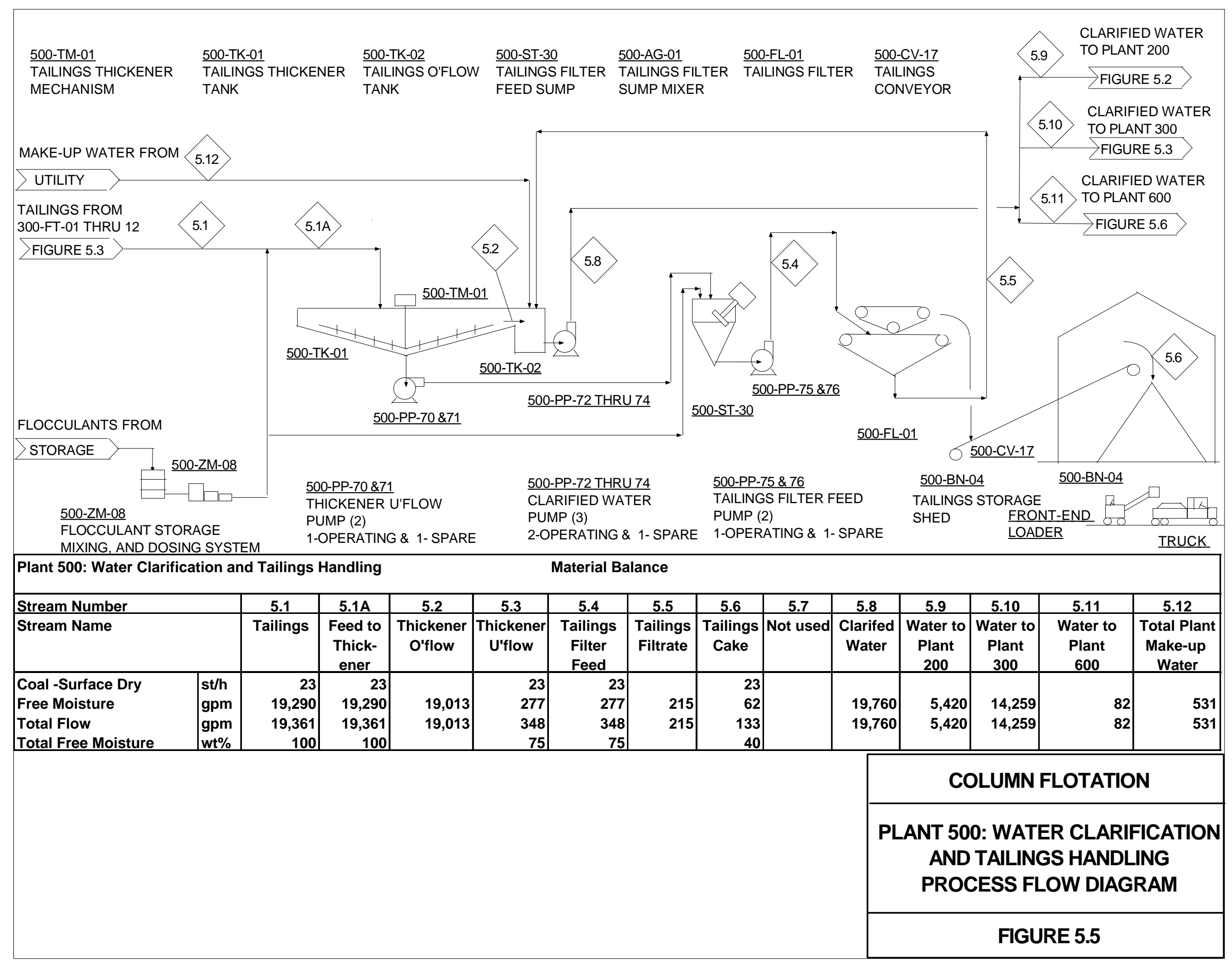




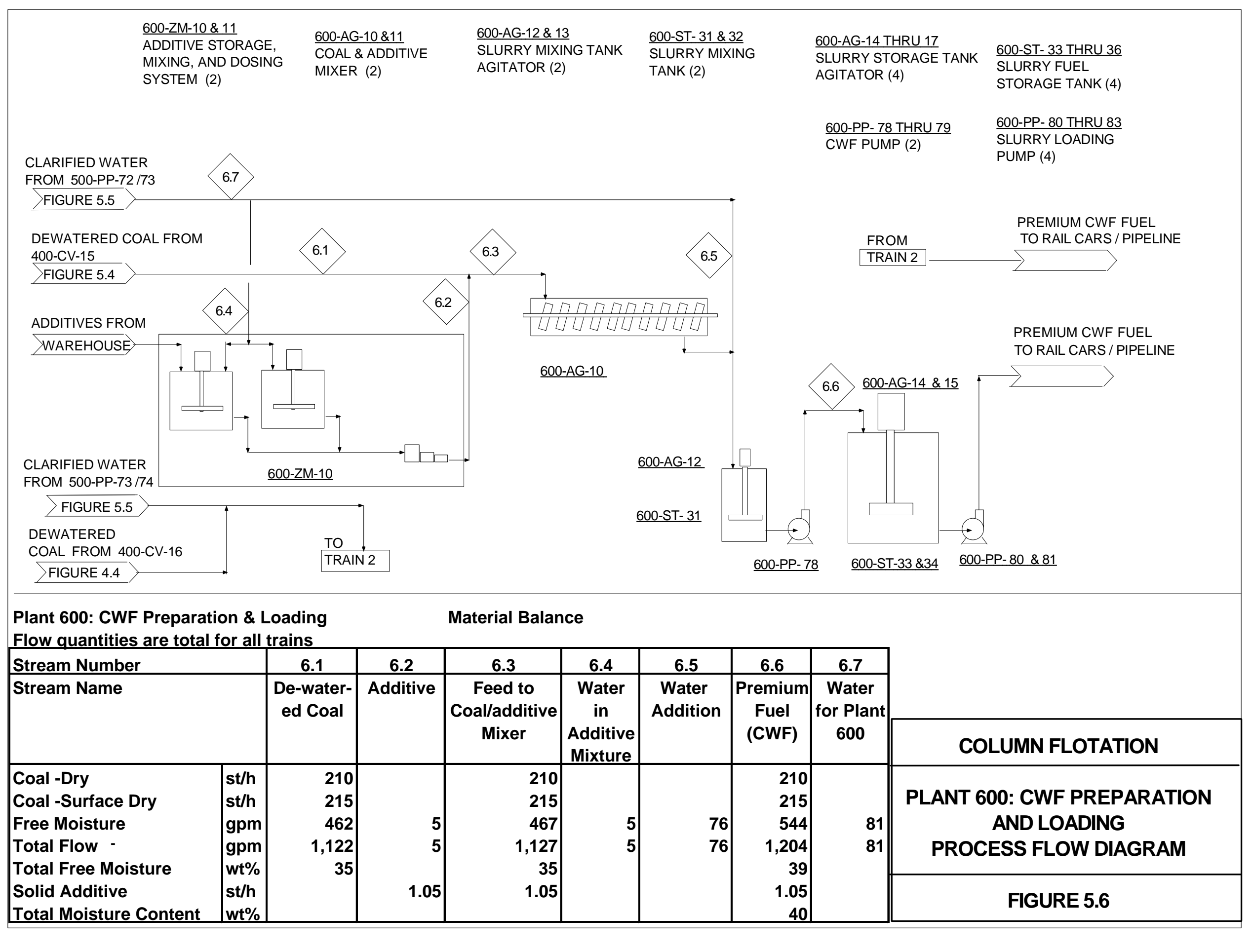




\section{Section 6 \\ Conceptual Design of CWF Plant - Selective Agglomeration}

A conceptual design for a commercial plant based on selective agglomeration technology for the production of premium CWF is presented in this section. A discussion of the process design criteria and a description of the integrated facility are also included.

\subsection{PROCESS DESIGN CRITERIA-SELECTIVE AGGLOMERATION}

The laboratory, bench-scale, and PDU testing conducted earlier form the bases for process design and equipment selection criteria used in the conceptual design. These are summarized in Table 6.1.1.

With the design coal, it is expected that selective agglomeration will achieve a heating value recovery of 99 percent while producing specification quality clean coal. A clean coal weight recovery of 93 percent will be achieved. As noted in Section 4, the plant operates 3 shifts a day and 19 shifts of the week. There is an annual shut down for two weeks for major maintenance work. Based on the schedule, the weight recovery, and an availability of 91 percent of scheduled operating time, a design input capacity of $233 \mathrm{st} / \mathrm{h}$ (dry basis) has been calculated to produce 1.5 million st of clean coal on a dry basis. If the availability is calculated on the basis of a total of 8,760 hours (365 x 24) in a year, the selected hourly design capacity reflects an availability of 79 percent. This level of availability is considered achievable with multiple (10 trains) and adequate complement of standby equipment at critical locations of the plant. Scale-up issues were considered in deciding the capacity and total number of trains used.

Significant process and equipment design parameters such as energy for grinding, solids concentration of the agglomeration feed, retention times for agglomeration, the number and stages of agglomeration, consumption of power for agglomeration, and the criteria for the heptane recovery circuit are shown in Table 6.1.1. The table also provides details of process and equipment design criteria for clean coal dewatering, water clarification, tailings dewatering and handling, CWF preparation, and loading sections of the plant.

Operating experience and recent analysis of test data from the PDU indicate certain potential improvements to agglomeration plant design and criteria. These are presented below for the benefit of future plant designs.

Froth Skimmer Design: A slender column with a relatively small cross section area would be more effective than the 5 feet diameter unit used in the $2 \mathrm{t} / \mathrm{h}$ PDU. Such an unit will allow improved nitrogen dispersion across the column and provide higher solids/area ratio for the froth layer.

Screen spraty/wash water: Recent experience would indicate a spray water rate of 8.3 gpm per ton per hour of clean coal agglomerates. 
Solid Concentration in Low Shear Reactor: For some coals, a solid concentration of 8 percent combined with a retention time of 2 minutes improved product qualtity at the same level of energy recovery. The concept designs are based on a solids concentration of 10 percent and a retention time of 3 minutes.

Grind Size: Tests indicate that, for the same low ash content product, a finer coal grind is often needed with the Selective Agglomeration Process as compared to Column Flotation. Selective agglomeration tends to place coal particles aggressively in the clean coal. As a result, even particles with minor coal surface are collected as clean coal. Such behavior of the process dilutes product quality and creates a need for finer grinding and better liberation of the feed.

\subsection{FACILITY DESCRIPTION}

The commercial CWF plant based on selective agglomeration consists of the following sections:

- Raw Coal Handling - Plant 100

- $\quad$ Crushing and Grinding - Plant 200

- $\quad$ Selective Agglomeration - Plant 350

- Clean Coal Dewatering - Plant 400

- Water Clarification and Tailings Handling - Plant 600

- $\quad$ CWF Preparation and Loading - Plant 600

A list of major equipment is provided under Table 6.2.1

\subsubsection{Raw Coal Handling - Plant 100}

A process flow diagram for the raw coal handling section, Plant 100, is presented in Figure 6.1. It is identical to the raw coal handling section described under Section 5.2.1 for the plant based on column flotation.

Raw coal, pre-crushed to a top size of 2 inch, is delivered to the CWF plant in RR cars. The cars are unloaded using a car dumper. The rail car unloading system includes thawing sheds for heating the cars during the winter months when freezing conditions could be encountered. A shunting locomotive is used to position the cars over the dumper. The cars are dumped, one car at a time, into a 200 ton dump hopper. A bar grid located at the top of the dump hopper prevents large lumps of frozen coal from entering the hopper. A frozen coal crusher is used to break such lumps of coal over the grid.

Two variable capacity belt feeders located below the dump hopper deliver the coal to a raw coal conveyor which transports and elevates the coal to the top of the coal silos.

The raw coal conveyor working with two silo feed conveyors fills three raw coal concrete silos. Each silo has a capacity of 10,000 st. 
The raw coal handling section is rated for a capacity of $2000 \mathrm{st} / \mathrm{h}$. It includes a comprehensive dust collection system to control emission of dust during coal dumping and conveying operations.

\subsubsection{Crushing and Grinding - Plant 200}

Figure 6.2 represents a process flow diagram for this plant section. A material and heat balance is shown in Table 6.2.2. This plant section is similar to the one provided for the plant based on column flotation and described in Section 5.2.2.

The crushing and grinding section includes two parallel and identical trains to crush and grind the coal ahead of selective agglomeration. Two variable speed belt feeders are provided below each of the coal silos for withdrawal of coal. Two crusher feed conveyors receive coal from the belt feeders. The conveyors deliver the coal to two hammer mill type crushers. The crushers are designed to crush the coal to a top size of 1/2 inch. Tramp iron magnets are included for the protection of the hammer mills. Crushed coal from the hammer mills is delivered to the ball mills by two ball mill feed conveyors. Each conveyor serves a grinding system.

Each grinding system includes a 4000 HP ball mill served by a set of three cyclone clusters for closed circuit operation. Each cyclone cluster has multiple cyclones. Coal is ground in the mills with water. The discharge slurry from each ball mill is diluted and pumped to the cyclone clusters. A distributor is used to distribute the flow equally among the cyclone clusters. Partially ground material exiting the cyclone apex (cyclone underflow) is returned to the mills for further grinding.

The over flow from cyclones represents the ground slurry. The solids content of the slurry is controlled at a preset value of approximately 15 percent by the addition of water. The slurry is sluiced to the selective agglomeration section, Plant 350.

\subsubsection{Selective Agglomeration - Plant 350}

Sheets 1 through 5 of Figure 6.3 represent process flow diagrams for the selective agglomeration section, Plant 350. Material and heat balances are shown in Table 6.2.3.

Ground slurry from each of the two trains of the crushing and grinding plant (Plant 200) is received in a 5-way distributor. Each of the two distributors splits the feed slurry equally to 5 agglomeration trains. The ten parallel agglomeration trains included in the section are identical except for some equipment which are shared by two trains. Such shared equipment are clearly identified in the equipment list and process flow diagrams. The following description addresses one of the agglomeration trains.

Production of Agglomerates Feed coal slurry from the distributor is received in the agglomeration feed tank. The slurry is then pumped to a high shear reactor (HSR) vessel. A measured stream of heptane from a metering pump joins the feed coal slurry ahead of the HSR vessel. Under conditions of the intense agitation in HSR vessel created by the impeller a phase inversion takes place. Micro agglomerates of ultra-clean coal are formed. Particles of hydrophobic coal coalesce as agglomerates with heptane acting as the bridging liquid. Hydrophilic particles of mineral matter (the tailings) remain dispersed in 
water as discrete particles. The slurry with the micro agglomerates overflows from the HSR vessel and flows through a set of two low shear reactor (LSR) vessels. The vessels are arranged in series. A measured amount of water is added in the first LSR vessel to dilute the slurry. In the LSR vessel the micro agglomerates grow to approximately $3 \mathrm{~mm}$ in diameter, under relatively gentle agitation conditions. The slurry from the second LSR vessel overflows to a vibrating screen. Here the agglomerates are separated from the slurry which is laden with non-coal mineral matter. The agglomerates are sprayed with water on the screen deck to help remove tailings adhering to the agglomerates. The screened agglomerates are now ready for the heptane stripping.

The underflow from the screen, which is essentially water laden with mineral matter (tailings) flow into a froth skimmer tank with a conical bottom. The tank is provided with a rotating froth skimmer at the top. The tendency of coal agglomerates to float in water is used in this tank to capture any misplaced coal present in the tailings as part of the screen under flow. The floating coal agglomerates in the tank are skimmed and directed to the main agglomerate stream from the vibrating screen. Heated clarified water is used as push water in the launder for the floats.

The slurry from the bottom of the froth skimmer tank, the tailings, are pumped to a sampling pot. At the sampling pot a constant stream of purge nitrogen is passed through the slurry. A hydrocarbon detector constantly scans the nitrogen exiting the sampling pot for the presence of heptane. If no heptane is detected, the tailings stream is directed to a tailings thickener included in Plant 500. When the presence of heptane is detected, the tailings slurry is directed to a slop tank instead of the tailings thickener.

The slop tank serves as a holding vessel for off grade slurries and spills that could contain heptane. Periodically, the contents of the tank are heated with steam to vaporize the heptane and render the slurry heptane free. The processed slurry is sent to the tailings thickener. 
Heptane Stripping Heptane in the coal agglomerates is vaporized and recovered during the heptane stripping operation. It is vaporized in two stages to enhance recovery of heptane.

The screened agglomerates and the material from the froth skimmer are collected in a steam stripper feed drum. The contents of the drum are diluted by the addition of heated clarified water to a pumpable consistency and pumped to the first stage steam stripper, steam stripper A. In this vessel which is provided with an agitator, the slurry is heated by steam from the second stage steam stripper (steam stripper B) to a temperature of approximately 225 degrees F. The vessel is maintained at a pressure of 1 to 3 psig. Close to the entire quantity (99\%) of heptane in the agglomerates and some water are vaporized. The slurry in stripper A is then pumped to steam stripper B which is maintained at a higher pressure of 5 to $10 \mathrm{psig}$ for the removal of last traces of heptane in the agglomerates. Steam at a pressure of $20 \mathrm{psig}$ is sparged through the contents of stream stripper B to elevate slurry temperature and vaporize heptane and water. Vapors from steam stripper B are passed through steam stripper A. The vapors raises slurry temperature and vaporizes heptane with water in steam stripper A.

Vapors from steam stripper A are condensed in an air cooler. The condensed liquids, water and heptane, are further cooled to a temperature of $80^{\circ} \mathrm{F}$ in a heat exchanger. Cooling is done with chilled water. The cooled liquids gravitate to an oil/water separator where the two liquids are separated using gravity. Liquid heptane from the separator is sent to a heptane drum for reuse. Metering pumps deliver heptane from the drum back to the feed end of the agglomeration section.

Water from the oil/water separator is passed through activated carbon in a carbon drum and used again for steam raising.

Approximately 220,000 lb. per hour of steam at a pressure of $20 \mathrm{psig}$ will be required for the heptane stripping operation. This amount of relatively low pressure steam is produced most economically in a local power station (It is assumed that a power station will be in the vicinity to produce and sell steam to the CWF plant).

After heptane stripping, the hot clean coal slurry from steam stripper B is cooled in two stages. In the first stage of cooling, clarified recycle water is used for cooling. The heated clarified water is used in the system to dilute and pre-heat the slurry in the steam stripper feed drum. It is also used as a push water in the froth skimmer. Thus a significant amount of heat in the hot clean coal slurry is recycled. In the second stage of cooling, the clean coal slurry is cooled using pond water. Cooled clean coal slurry at $80^{\circ} \mathrm{F}$ is piped to slurry distributors in the clean coal dewatering section, Plant 400.

Gas Blanketing System All vessels in this plant section which could contain heptane are connected to a nitrogen gas blanketing system which is constantly maintained at a positive pressure of 3 to 6 inches of water. The gas blanket prevents ingress of atmospheric air into the vessels where it could form a flammable mixture with heptane vapors. A gas holder forms part of the nitrogen blanketing system. It helps maintain a constant positive pressure in the system. By increasing or decreasing the hold up, the variable volume gas holder accommodates volume changes in the blanketing system due to temperature changes and variations in the void volumes of vessels. Should nitrogen 
be lost from the system for any reason it will be indicated by a low level in the gas holder. In such an instance the losses are made-up by drawing gas from a liquid nitrogen package.

The liquid nitrogen package also provides gas for purging vessels and displace all air in them at the start of operations.

During occasions of excessive build up of nitrogen in the system indicated by a high level in the gas holder, the surplus gas is flared off.

The plant is also provided with a relief vent system. This system will kick-in if pressure in side any vessels should exceed pre-set value.

Building areas handling heptane are provided with heptane vapor detectors that are connected to dedicated ventilation fans. Should heptane vapors be detected due to a spill, the ventilation fans are activated immediately to thoroughly ventilate the area and render it safe. A comprehensive fire prevention and protection system is also included.

Cooling water supply for the plant is from two on-site lined ponds. The closed cooling water circuit will use atmospheric cooling and evaporation to maintain required water temperatures. In addition, a chiller is used to provide refrigerated cooling water during summer months for use in cooling circuits which need cooling water at $50^{\circ} \mathrm{F}$.

\subsubsection{Clean Coal Dewatering - Plant 400}

Figure 6.4 shows a process flow diagram for this plant section. A material and heat balance is given in Table 6.2.4. This section is very similar to the one described in Section 5.2.4 under Design of CWF Plant - Column Flotation.

The clean coal dewatering section consists of two identical trains. Each train is provided with six parallel vacuum filtration lines. Clean coal slurry is dewatered and a filter cake with a moisture content of approximately 37 percent (35 percent surface moisture) is produced. Filter cake from each set of six filters is collected by a dewatered coal conveyor. The two dewatered coal conveyors deliver the coal to two coal- additive mixers provided under Plant 600.

The water separated by the vacuum filters, the filtrate, may contain some solids. It is therefore pumped to the tailings thickener. Coal solids in the filtrate, if any, tends to float in the thickener. These are removed periodically.

All pumps in this section are provided with installed spares.

\subsubsection{Water Clarification and Tailings Handling - Plant 500}

Figure 6.5 presents a process flow diagram for this plant section. A material and heat balance appears in Table 6.2.5. This plant section is similar to the one described in Section 5.2.5 for plant design based on column flotation.

Tailings slurry from selective agglomeration are collected in a thickener. The tailings (solids) are thickened and the water is clarified with the addition of measured amounts of flocculants to the feed slurry. The thick underflow from the thickener is pumped to a tailings filter sump. Additional amounts of flocculants are mixed with the slurry in the 
filter sump to facilitate filtering. A continuous Andritz type belt filter is used to dewater the tailings.

The filtered tailings are collected by a tailings conveyor and conveyed to a storage pile under a shed. The tailings are loaded into trucks using front-end loaders for transport and disposal at a landfill.

Clarified water from the thickener, the thickener overflow, is recirculated to the CWF preparation, selective agglomeration, and grinding sections of the facility. The water sent to the later two plant sections is cooled in a heat exchanger for removal of excess heat from the plant system. Chilled water is used in this heat exchanger.

\subsubsection{CWF Preparation and Loading - Plant 600}

A process flow diagram for this plant section is shown in Figure 6.6. The material and heat balance is presented in table 6.2.6. This plant section also comprises two parallel and identical trains. This plant section comprises two parallel and identical trains. It is identical to the one described in Section 5.2.6 for plant design based on column flotation.

Dewatered clean coal from the vacuum filters (the filter cake) is fed to two coal-additive mixers (one on each train). Here the cake is mixed intensely with the dispersant additive A-23 to obtain a good dispersal of the additive. The mixture is then fed to slurry mix tanks (one in each train) where measured amounts of water is added to obtain the desired solids content in the prepared CWF. From the slurry mix tanks, the CWF is pumped to storage tanks.

A total of four storage tanks are included with adequate capacity to hold a two day production of CWF. From the storage tanks, the CWF is pumped into RR tank cars. Alternately, the slurry fuel in the storage tanks may be pumped to nearby clients through pipe lines installed by others. 
Table 6.1.1

\section{COMMERCIAL CWF PLANT- SELECTIVE AGGLOMERATION} Process Design Criteria

\begin{tabular}{|c|c|c|c|}
\hline III & $\begin{array}{l}\text { SELECTIVE AGGLOMERATION PERFORMANCE } \\
\text { Heating value recovery } \\
\text { Feed ash content- dry basis } \\
\text { Feed HHV- dry basis } \\
\text { Weight recovery } \\
\text { Product ash- dry basis } \\
\text { Product HHV-dry basis } \\
\text { Ash per million Btu of HHV in the product } \\
\text { OPERATING SCHEDULE } \\
\text { Hours per shift } \\
\text { Shifts per day } \\
\text { Days per week } \\
\text { Scheduled maintenance shifts per week } \\
\text { Scheduled operating shifts per } 7 \text { day week } \\
\text { Scheduled operating weeks per year } \\
\text { Scheduled operating hours per year } \\
\text { DESIGN HOURLY FEED RATE TO AGGLOMERATION } \\
\text { Annual output required - dry basis } \\
\text { Average output per operating hour-dry basis } \\
\text { Plant utilization based on scheduled operating hrs } \\
\text { Design output capacity-dry basis } \\
\text { Design weight recovery } \\
\text { Plant design input capacity-dry basis } \\
\text { Inherent moisture } \\
\text { Plant design input capacity-surface dry basis } \\
\text { Plant availability based on } 24 \text { h/day and } 365 \text { d/y } \\
\text { AGGLOMERATION FEED SLURRY PREPARATION } \\
\text { Grinding circuit configuration } \\
\text { Ground product - nominal, } 100 \% \text { passing } \\
\text { Size (D80) } \\
\text { Size of coal feed to grinding mills } \\
\text { Specific power for grinding } \\
\text { Agglomeration feed solids content } \\
\text { Storage for ground slurry } \\
\text { SELECTIVE AGGLOMERATION } \\
\text { High shear reactor (HSR) } \\
\text { Feed solids content (dry basis) } \\
\quad \text { Retention time } \\
\quad \text { Design feed to agglomeration -dry basis } \\
\quad \text { Water flow rate } \\
\quad \text { Design slurry flow rate } \\
\text { Power for agglomeration }\end{array}$ & $\begin{array}{c}\% \\
\% \\
\text { Btu/b } \\
\% \\
\% \\
\text { Btu/lb } \\
\text { lb/MBtu } \\
\text { h/shift } \\
\text { shifts/day } \\
\text { days/week } \\
\text { shifts/week } \\
\text { shifts/week } \\
\text { weeks/y } \\
\text { h/y } \\
\text { Million st/y } \\
\text { st/h } \\
\% \\
\text { st/h } \\
\% \\
\text { st/h } \\
\text { wt } \% \\
\text { st/h } \\
\% \\
\text { mesh } \\
\text { in. } \\
\text { mesh } \\
\text { wt } \% \\
\\
\end{array}$ & $\begin{array}{r}99.0 \\
7.5 \\
14,054 \\
93.0 \\
2.8 \\
14,962 \\
<2.0 \\
\\
8 \\
3 \\
7 \\
2 \\
19 \\
50 \\
7,600 \\
\\
1.5 \\
197 \\
91 \\
217 \\
93.0 \\
233 \\
2.0 \\
238 \\
79 \\
\end{array}$ \\
\hline
\end{tabular}


Table 6.1.1 (continued)

\section{COMMERCIAL CWF PLANT- SELECTIVE AGGLOMERATION Process Design Criteria}

Total volume required in HSRs

Number of parallel circuits

Volume of each HSR

Required dia : ht ratio

Calculated minimum diameter of HSR

Calculated minimum height of HSR

Selected dia $\mathrm{x}$ ht (Arcanum recommendation)

Material of construction:

Vessel

Impeller, shaft, baffles, and vessel attachments

Motor Power (Arcanum recommendation)

Power per impeller based on total No. selected

Variable speed drive

Low shear reactor (LSR)

Feed solids content -dry basis

Retention time

Design feed to agglomeration -dry basis

Design water flow rate

Design slurry flow rate

Volume required in LSR

Assumed number of trains

LSR Volume of each trains

No. of LSR in each train- arranged in series

LSR Volume - each unit

Required dia : ht ratio

Calculated minimum diameter of LSR

Calculated minimum height of LSR

Selected dia $\mathrm{x}$ ht (Arcanum recommendation)

Material of construction:

Vessel

Impeller, shaft, baffles, and vessel attachments

Motor Power (Arcanum recommendation)

Power per impeller based on total No. selected

Variable speed drive

\section{Agglomerate Screen}

Inclined screen-( $6^{\circ}$ downhill), 48 mesh deck,

thin solid layer with water sprays

Dilution water addition in o'flow launder- temp.

\section{Froth Skimmer}

Froth solids - wt \% of total clean coal

Moisture content of froth (before water addition)

Temperature of flush water to froth launder

\begin{tabular}{c|r} 
& \\
gallon & 3,002 \\
& 10 \\
gallon & 300 \\
& $1: 2$ \\
in. & 35.32 \\
in. & 70.6 \\
in. $\mathrm{x}$ in. & $38 \times 80$ \\
& $\mathrm{CS}$ \\
$\mathrm{kW} /(\mathrm{st} / \mathrm{h})$ & $\mathrm{SS}$ \\
$\mathrm{kW}$ & 12.5 \\
& 292
\end{tabular}

Not Required

wt \%

seconds

10

180

233

$\mathrm{st} / \mathrm{h}$

8,397

gpm

9,114

gpm

gallons

27,343

10

gallons

2734

gallons

2

1,367

$1: 2$

in.

58.5

in.

117.1

in. $x$ in.

$60 \times 120$

CS

SS

$\mathrm{kW} /(\mathrm{st} / \mathrm{h})$

$\mathrm{HP} /(\mathrm{st} / \mathrm{h})$

$\mathrm{kW}$

Not Required

${ }^{\circ} \mathrm{F}$

190

wt \%

wt \%

60

${ }^{\circ} \mathrm{F}$

190 


\section{Table 6.1.1 (continued) \\ COMMERCIAL CWF PLANT- SELECTIVE AGGLOMERATION \\ Process Design Criteria}

\begin{tabular}{|c|c|c|c|}
\hline VII & $\begin{array}{l}\text { Steam Stripper A } \\
\text { Solid content of slurry - stripper outlet } \\
\text { Residence time } \\
\text { Normal operating pressure } \\
\text { Normal vapor composition by wt; Heptane : Water } \\
\text { Steam Stripper B } \\
\text { Residence time } \\
\text { Normal operating pressure } \\
\text { CLEAN COAL DEWATERING } \\
\text { Equipment type } \\
\text { Filter cake moisture content } \\
\text { WATER CLARIFICATION AND TAILINGS DEWATERING } \\
\text { Equipment type } \\
\text { Tailings thickener -Specific thickening rate } \\
\text { Thickener under flow -surface moisture content } \\
\text { Tailings filter- type } \\
\text { Moisture content of dewatered tailings, filter cake } \\
\text { CWF PREPARATION AND LOADING } \\
\text { Dispersant type } \\
\text { Dispersant (Solid) dosage per dry ton of coal } \\
\text { Water content of additive solution } \\
\text { Stabilizer } \\
\text { Storage capacity for CWF at site } \\
\text { Type of storage } \\
\text { Rail car loading rate: } \\
\text { CWF } \\
\text { Coal on a dry basis }\end{array}$ & $\begin{array}{l}\text { wt } \% \\
\text { minutes } \\
\text { psig } \\
\text { Ratio } \\
\text { minutes } \\
\text { psig } \\
\text { wt \% }\end{array}$ & $\begin{array}{r}30 \\
5 \\
3 \\
100: 70 \\
\\
10 \\
10 \\
\\
\text { Vacuum filter } \\
35 \\
\\
\text { Thickener and Filter } \\
2.0 \\
75 \\
\text { Belt press } \\
40 \\
\\
\text { A-23 } \\
10 \\
55 \\
\text { Not used } \\
48 \\
\text { Agitated tanks } \\
3,000 \\
500\end{array}$ \\
\hline
\end{tabular}


Table 6.2.1

COMMERCIAL CWF PLANT- SELECTIVE AGGLOMERATION

Major Equipment List

\begin{tabular}{|c|c|c|c|c|c|}
\hline $\begin{array}{l}\text { Equipment } \\
\text { I.D }\end{array}$ & Qty & Title & Description & $\begin{array}{c}\text { Power (ea) } \\
\text { HP }\end{array}$ & $\begin{array}{c}\text { Total } \\
\text { installed } \\
\text { HP }\end{array}$ \\
\hline $100 \mathrm{BN}-01,02,03$ & 3 & $\begin{array}{l}\text { Raw coal silos, No. 1, 2, } \\
\text { and } 3\end{array}$ & $10,000 \mathrm{st}(\mathrm{ea}), 70 \mathrm{ft}$ dia $\times 150 \mathrm{ft}$ ht & & \\
\hline 100 CV-01 & 1 & Raw coal conveyor & $\begin{array}{l}2000 \mathrm{st} / \mathrm{h}, 60 \mathrm{in} \text { wide } \times 750 \mathrm{ft} \text { lg., } 220 \\
\mathrm{ft} \text { lift, } 500 \mathrm{fpm} \text {, with belt scale }\end{array}$ & 600 & 600 \\
\hline $100 \mathrm{CV}-02$ & 1 & Silo feed conveyor No. 1 & $\begin{array}{l}2000 \mathrm{st} / \mathrm{h}, 60 \text { in wide } \times 80 \mathrm{ft} \text { lg., } 10 \mathrm{ft} \\
\text { lift, } 500 \mathrm{fpm}\end{array}$ & 50 & 50 \\
\hline $100 \mathrm{CV}-03$ & 1 & Silo feed conveyor No. 2 & $\begin{array}{l}2000 \mathrm{st} / \mathrm{h}, 60 \text { in wide } \times 80 \mathrm{ft} \text { lg., no } \\
\text { lift, } 500 \mathrm{fpm}\end{array}$ & 50 & 50 \\
\hline 100 DC-01,02,03 & 3 & $\begin{array}{l}\text { Silo top dust collector with } \\
\text { fan }\end{array}$ & $\begin{array}{l}7000 \text { cfm, filtering area } 1200 \text { sq. ft } \\
\text { including fan }\end{array}$ & 40 & 120 \\
\hline $100 \mathrm{RR}-01$ & Lot & Rail car unloading system & $\begin{array}{l}\text { For } 2000 \text { st/h unloading rate } \\
\text { including rotary car dumper, shunting } \\
\text { locomotive, } 200 \text { st dump hopper, } \\
\text { grizzly, frozen coal crusher, thawing } \\
\text { shed, dust collection, raw coal } \\
\text { conveyor tunnel, sump pump, } \\
\text { feeders, rail track of } 2 \text { miles }\end{array}$ & 700 & 700 \\
\hline 100 ST-01 \& 02 & 2 & Motorized gate & Capacity- 2000 st/h & 10 & 20 \\
\hline 200 AG-01 \& 02 & 2 & $\begin{array}{l}\text { Cyclone feed pump sump } \\
\text { mixers }\end{array}$ & For Cyclone feed sump & 15 & 30 \\
\hline $200 \mathrm{CN}-01$ & 1 & Mill house crane & 30 t main hook, 5 ton aux & 75 & 75 \\
\hline 200 CR-01,02 & 2 & Hammer mill crusher & $\begin{array}{l}125 \mathrm{st} / \mathrm{h} \text {, feed size 2" x } 0 \text { and product } \\
1 / 4 " \text { × } 0\end{array}$ & 300 & 600 \\
\hline 200 CS-01 thru 06 & 6 & Cyclone cluster & $\begin{array}{l}\text { Flow } 1200 \mathrm{gpm} / \text { cluster-20 no. of } 4 \text { in } \\
\text { cyclones per cluster }\end{array}$ & & \\
\hline 200 CV-10 \& 11 & 2 & Crusher feed conveyor & $\begin{array}{l}125 \mathrm{st} / \mathrm{h}, 30 \text { in wide } \times 300 \mathrm{ft} \text { lg., } 25 \mathrm{ft} \\
\text { lift, } 350 \mathrm{fpm} \text {, with belt scale }\end{array}$ & 15 & 30 \\
\hline 200 CV-12 \& 13 & 2 & Ball mill feed conveyor & $\begin{array}{l}125 \mathrm{st} / \mathrm{h}, 30 \text { in wide } \times 100 \mathrm{ft} \text { lg., } 25 \mathrm{ft} \\
\text { lift, } 350 \mathrm{fpm}\end{array}$ & 15 & 30 \\
\hline 200 DC-10 \& 11 & 2 & $\begin{array}{l}\text { Crusher House dust } \\
\text { collector with fan }\end{array}$ & & 50 & 100 \\
\hline 200 FE-01 thru 06 & 6 & Reclaim feeders & $\begin{array}{l}125 \mathrm{st} / \mathrm{h}, 36 \text { in wide } \times 40 \mathrm{ft} \lg ., 75 \mathrm{fpm}, \\
(\mathrm{max} .) \text { variable speed drive }\end{array}$ & 10 & 60 \\
\hline 200 MA-01 \& 02 & 2 & Tramp Iron Magnet & $125 \mathrm{st} / \mathrm{h}, 36$ in belt & 10 & 20 \\
\hline $200 \mathrm{ML}-01 \& 02$ & 2 & Ball Mill & $125 \mathrm{st} / \mathrm{h}, 14.5 \mathrm{ft}$ dia $\times 29 \mathrm{ft}$ & 4000 & 8000 \\
\hline 200 PP-01 thru 04 & 4 & Cyclone feed pump & $\begin{array}{l}\text { Horizontal slurry pump, flow } 3500 \\
\text { gpm, sp gr } 1.2, \mathrm{TDH} 130 \mathrm{ft}, 2 \\
\text { operating and } 2 \text { spare }\end{array}$ & 225 & 900 \\
\hline $\begin{array}{l}350 \text { PP-175 thru } \\
178\end{array}$ & & Not used & & & \\
\hline 200 ST-03 thru 8 & 6 & Motorized gate & Capacity- $125 \mathrm{st} / \mathrm{h}$ & 5 & 30 \\
\hline 200 ST-10 \& 11 & 2 & Cyclone feed sump, & $\begin{array}{l}7000 \text { gal capacity (2 min.)-14ft dia } x \\
15 \mathrm{ft} \text { ht, conical }\end{array}$ & & \\
\hline 200 ZM-01 \& 02 & 2 & Distributor & 3 way-3500 gpm & 5 & 10 \\
\hline 350 AG-90 thru 99 & 10 & Feed tank agitator & Tank volume -4000 gals. & 1.5 & 15 \\
\hline
\end{tabular}


Table 6.2.1 (continued)

COMMERCIAL CWF PLANT- SELECTIVE AGGLOMERATION

Major Equipment List

\begin{tabular}{|c|c|c|c|c|c|}
\hline $\begin{array}{l}\text { Equipment } \\
\text { I.D }\end{array}$ & Qty & Title & Description & $\begin{array}{c}\text { Power (ea) } \\
\text { HP }\end{array}$ & $\begin{array}{c}\text { Total } \\
\text { installed } \\
\text { HP }\end{array}$ \\
\hline $\begin{array}{l}350 \text { AG-100 thru } \\
109 \\
\end{array}$ & 10 & HSR impeller & Special & 400 & 4000 \\
\hline $\begin{array}{l}350 \text { AG-109 thru } \\
129\end{array}$ & 20 & LSR impeller & Special & 50 & 1000 \\
\hline $\begin{array}{l}350 \text { AG-130 thru } \\
139\end{array}$ & 10 & Froth skimmer & & 5 & 50 \\
\hline $\begin{array}{l}350 \text { AG-140 thru } \\
149 \\
\end{array}$ & & Not used & & & \\
\hline $\begin{array}{l}350 \text { AG-150 thru } \\
159 \\
\end{array}$ & 10 & Steam stripper A agitator & & 20 & 200 \\
\hline $\begin{array}{l}350 \text { C-100 thru } \\
109\end{array}$ & 10 & HSR vessel & \begin{tabular}{|l|} 
Volume: 360 gals. Diameter: 38 inch \\
ht 88 inch - CS- Design Pressure 15 \\
psig- Temp 145 deg F. 34 secs.
\end{tabular} & & \\
\hline $\begin{array}{l}350 \mathrm{C}-110 \text { thru } \\
129\end{array}$ & 20 & LSR vessel & $\begin{array}{l}\text { Volume } 1445 \text { gals. Diameter: } 60 \text { inch } \\
\text { ht } 132 \text { inch - CS- Design Pressure } 15 \\
\text { psig- Temp } 145 \text { deg F. } 184 \text { secs. }\end{array}$ & & \\
\hline $\begin{array}{c}350 \text { C-130 thru } \\
139 \\
\end{array}$ & 10 & Froth skimmer tank & Volume: 2000 gals.- 2.5 min & & \\
\hline $\begin{array}{c}350 \text { C-140 thru } \\
149\end{array}$ & 10 & Steam stripper feed drum & Volume: 300 gals.- 1 min & & \\
\hline $\begin{array}{c}350 \text { C-150 thru } \\
159\end{array}$ & 10 & Steam stripper A & Volume: 1500 gals.- 5 min & & \\
\hline $\begin{array}{l}350 \text { C-160 thru } \\
169\end{array}$ & 10 & Steam stripper B & Volume: 3000 gals.- 10 min & & \\
\hline $\begin{array}{c}350 \mathrm{C}-170 \text { thru } \\
179 \\
\end{array}$ & 10 & Oil/water separator & Volume: 750 gals. - 15 min & & \\
\hline $\begin{array}{l}350 \text { C-180 thru } \\
189\end{array}$ & 10 & Sampling pot & Volume: 200 gals. - 15 secs & & \\
\hline $\begin{array}{c}350 \text { C-190 thru } \\
194\end{array}$ & 10 & Heptane drum & Volume: 700 gals. - 20 min & & \\
\hline $\begin{array}{c}350 \text { C-195 thru } \\
199\end{array}$ & 5 & Emergency slop tank & Volume: 5000 gals & & \\
\hline $\begin{array}{l}350 \text { C-200 thru } \\
204\end{array}$ & 5 & Carbon filter drum & Volume:600 gals & & \\
\hline $\begin{array}{c}350 \text { C-204 thru } \\
209\end{array}$ & 5 & Relief KO drum & Volume: 800 gals & & \\
\hline $350 \mathrm{CP}-01$ & 1 & Air compressor & $\begin{array}{l}1000, \text { SCFM, } 125 \text { psig with air } \\
\text { receiver }\end{array}$ & 200 & 200 \\
\hline $\begin{array}{l}350 \mathrm{D}-100 \text { thru } \\
109\end{array}$ & 10 & Floor sump & 5000 gals. Concrete & & \\
\hline $350 \mathrm{D}-110 \& 111$ & 2 & Boiler feed water tank & 5000 gals. Concrete & & \\
\hline 350 D-112 \& 113 & 2 & Cooling water pond & 400,000 gals & & \\
\hline $\begin{array}{l}350 \text { E-100 thru } \\
109\end{array}$ & 10 & Vapor condenser & Air Cooler-Heat Duty: $11 \mathrm{MBtu} / \mathrm{h}$ & 60 & 600 \\
\hline $\begin{array}{l}350 \mathrm{E}-110 \text { thru } \\
119\end{array}$ & 10 & Condensate cooler & Plate type-Heat Duty: $1 \mathrm{MBtu} / \mathrm{h}$ & & \\
\hline
\end{tabular}


Table 6.2.1 (continued)

COMMERCIAL CWF PLANT- SELECTIVE AGGLOMERATION

Major Equipment List

\begin{tabular}{|c|c|c|c|c|c|}
\hline $\begin{array}{l}\text { Equipment } \\
\text { I.D }\end{array}$ & Qty & Title & Description & $\begin{array}{c}\text { Power (ea) } \\
\text { HP }\end{array}$ & $\begin{array}{c}\text { Total } \\
\text { installed } \\
\mathrm{HP}\end{array}$ \\
\hline $\begin{array}{l}350 \text { E-120 thru } \\
129\end{array}$ & 10 & Water preheater & Plate type-Heat Duty: 7 MBtu/h & & \\
\hline $\begin{array}{c}350 \mathrm{E}-130 \text { thru } \\
139\end{array}$ & 10 & Slurry cooler & Plate type-Heat Duty: $12 \mathrm{MBtu} / \mathrm{h}$ & & \\
\hline $\begin{array}{l}350 \mathrm{E}-140 \text { thru } \\
149\end{array}$ & 10 & Blanket gas cooler & Plate type-Heat Duty: $150,000 \mathrm{Btu} / \mathrm{h}$ & & \\
\hline $350 \mathrm{~F}-100$ & 1 & Steam lines & $\begin{array}{l}\text { Flow- } 2500 \mathrm{lb} \text { of steam at } 50 \text { psia- } \\
\text { heat required } 300 \mathrm{MBtu} / \mathrm{h}-\end{array}$ & & \\
\hline $350 \mathrm{~F}-102 \& 106$ & 5 & Flare & & & \\
\hline $\begin{array}{l}350 \text { PP-100 thru } \\
109\end{array}$ & 10 & HSR feed pump & $\begin{array}{l}\text { Horizontal slurry pump, flow } 800 \\
\text { gpm, sp gr } 1.02, \text { TDH } 80 \mathrm{ft}\end{array}$ & 30 & 300 \\
\hline $\begin{array}{l}350 \text { PP-110 thru } \\
119\end{array}$ & 10 & Tailings transfer pump & $\begin{array}{l}\text { Horizontal slurry pump, flow } 1000 \\
\text { gpm, sp gr } 1.01, \text { TDH } 50 \mathrm{ft}\end{array}$ & 25 & 250 \\
\hline $\begin{array}{l}350 \text { PP-120 thru } \\
129\end{array}$ & 10 & Sump pump & $\begin{array}{l}\text { Vertical slurry pump, flow } 50 \mathrm{gpm}, \mathrm{sp} \\
\text { gr } 1.2, \mathrm{TDH} 50 \mathrm{ft}\end{array}$ & 5 & 50 \\
\hline $\begin{array}{l}350 \text { PP-130 thru } \\
139\end{array}$ & 10 & $\begin{array}{l}\text { Steam stripper } A \text { feed } \\
\text { pump }\end{array}$ & $\begin{array}{l}\text { Diaphragm type, flow } 350 \text { gpm, sp gr } \\
\text { 1.05, Delta P } 20 \text { psi, Design temp } \\
240 \text { deg F }\end{array}$ & & \\
\hline $\begin{array}{l}350 \text { PP-140 thru } \\
149\end{array}$ & 10 & $\begin{array}{l}\text { Steam stripper B feed } \\
\text { pump }\end{array}$ & $\begin{array}{l}\text { Moyno type, flow } 350 \mathrm{gpm} \text {, sp gr } \\
\text { 1.05, Design Pressure } 50 \text { psi, Delta } \\
\text { P } 30 \text { psi, Design temp } 250 \text { deg F }\end{array}$ & 10 & 100 \\
\hline $\begin{array}{l}350 \text { PP-150 thru } \\
159\end{array}$ & 10 & Clean coal slurry pump & $\begin{array}{l}\text { Moyno type, flow } 350 \text { gpm, sp gr } \\
\text { 1.05, Design Pressure } 50 \text { psi, Delta } \\
\text { P } 30 \text { psi, Design temp } 250 \text { deg F }\end{array}$ & 10 & 100 \\
\hline $\begin{array}{l}350 \text { PP-160 thru } \\
169\end{array}$ & 10 & Heptane pump & $\begin{array}{l}\text { Metering type, flow } 400 \mathrm{gpm} \text {, sp gr } \\
\text { 0.7, Design Pressure } 30 \mathrm{psi} \text {, Delta P } \\
30 \text { psi, Design temp } 100 \mathrm{deg} F\end{array}$ & 10 & 100 \\
\hline $\begin{array}{l}350 \text { PP-170 thru } \\
174\end{array}$ & 5 & Emergency slop pump & $\begin{array}{l}\text { Diaphragm type, flow } 350 \text { gpm, sp gr } \\
\text { 1.05, Delta P } 20 \text { psi, Design temp } \\
220 \text { deg F }\end{array}$ & 10 & 50 \\
\hline $\begin{array}{l}350 \text { PP-175 thru } \\
178\end{array}$ & & Not used & & & \\
\hline $\begin{array}{l}350 \text { PP-179 thru } \\
183 \\
\end{array}$ & 5 & K. O. Drum pump & Horizontal water pump & 3 & 15 \\
\hline $\begin{array}{l}350 \text { PP-184 thru } \\
187\end{array}$ & 4 & Chilled water pump & $\begin{array}{l}\text { Horizontal water pump, flow } 1700 \\
\text { gpm, TDH } 120 \mathrm{ft}, 2 \text { Operating and } 2 \\
\text { spare }\end{array}$ & 3 & 12 \\
\hline $\begin{array}{l}350 \text { PP-188 thru } \\
191\end{array}$ & 4 & Cooling water pump & $\begin{array}{l}\text { Horizontal water pump, flow } 3000 \\
\text { gpm, TDH } 120 \mathrm{ft}, 2 \text { Operating and } 2 \\
\text { spare }\end{array}$ & 150 & 600 \\
\hline 350 ST-90 thru 99 & 10 & Agglomeration feed tank & capacity- 4000 gal (6 min) & & \\
\hline 350 ST-100 \& 101 & 2 & Chilled water tank & $\begin{array}{l}17500 \text { gal capacity }-14 \mathrm{ft} \text { dia } \times 16 \mathrm{ft} \text { ht } \\
\text { Cylindrical- } 10 \text { min total }\end{array}$ & & \\
\hline $350 \mathrm{~V}-101 \& 102$ & 2 & Nitrogen package & & & \\
\hline $350 \mathrm{~V}-103 \& 104$ & 2 & Chiller & duty=8.5 MBtu/h & 800 & 1600 \\
\hline
\end{tabular}


Table 6.2.1 (continued)

COMMERCIAL CWF PLANT- SELECTIVE AGGLOMERATION

Major Equipment List

\begin{tabular}{|c|c|c|c|c|c|}
\hline $\begin{array}{l}\text { Equipment } \\
\text { I.D }\end{array}$ & Qty & Title & Description & $\begin{array}{c}\text { Power (ea) } \\
\text { HP }\end{array}$ & $\begin{array}{c}\text { Total } \\
\text { installed } \\
\text { HP }\end{array}$ \\
\hline $350 \mathrm{Y}-100$ thru 109 & 10 & Screen & $\begin{array}{l}\text { Vibrating, Sizetech type, } 450 \text { upward, } \\
\text { linear, } 3.4 \mathrm{~mm} \text { stroke,1800 rpm, 6' x } \\
16^{\prime} \text { feet }\end{array}$ & 15 & 150 \\
\hline $350 \mathrm{Y}-110$ thru 114 & 5 & Gas holder and & & & \\
\hline 350 ZM-100 \& 101 & 2 & 5-way distributor & Flow- 3500 gpm & & \\
\hline 400 FT-10 thru 15 & 6 & Filtration systems & $\begin{array}{l}\text { Capacity } 40 \text { st } / \mathrm{h} \text { - vacuum filter } \\
\text { systems }\end{array}$ & 700 & 4200 \\
\hline 400 CV-15 \& 16 & 2 & Coal conveyor & $\begin{array}{l}\text { Capacity } 130 \mathrm{st} / \mathrm{h}-24 \text { in wide, } 125 \\
\text { st/h, } 30 \mathrm{ft} \text { lift, }\end{array}$ & 5 & 10 \\
\hline 400 PP-62 \& 65 & 4 & Filtrate pump & $\begin{array}{l}\text { Flow } 900 \text { gpm, TDH } 30 \mathrm{ft}, 2- \\
\text { Operating and 2- Spare }\end{array}$ & 15 & 60 \\
\hline 400 ST-26 \& 27 & 2 & Filtrate sump & Capacity- 5000 gal & & \\
\hline 400 ZM-05 \& 06 & 2 & Slurry distributor & Capacity-1500 gpm & 10 & 20 \\
\hline 500 AG-09 & 1 & $\begin{array}{l}\text { Tailings filter sump } \\
\text { agitator }\end{array}$ & Capacity of sump - 1000 gal & 10 & 10 \\
\hline $500 \mathrm{BN}-04$ & 1 & Tailings load-out shed & Capacity- 100 st & & \\
\hline $500 \mathrm{CV}-16$ & 1 & Tailings conveyor & Capacity - 50 st/h, 24 in x $100 \mathrm{ft}$ & 5 & 5 \\
\hline 500 FL-01 & 1 & Tailings filter & Capacity-30st/h, 3,5 m wide belt & 22 & 22 \\
\hline 500 PP-70 \& 71 & 2 & $\begin{array}{l}\text { Thickener underflow } \\
\text { pump }\end{array}$ & $\begin{array}{l}\text { Horizontal slurry- capacity } 500 \mathrm{gpm} \text {, } \\
50 \mathrm{ft} \text { head, sp gr 1.0, 1- Operating, } \\
1 \text { - Spare }\end{array}$ & 15 & 30 \\
\hline 500 PP-72 thru 74 & 3 & Clarified water pump & $\begin{array}{l}\text { Horizontal water- capacity } 5,000 \\
\text { gpm, } 80 \mathrm{ft} \text { head,. 2- operating, } 1 \text { - } \\
\text { spare }\end{array}$ & 150 & 450 \\
\hline 500 PP-75 \& 76 & 2 & Tailings filter feed pump & $\begin{array}{l}\text { capacity } 420 \mathrm{gpm}, 30 \mathrm{ft} \text { head, } \mathrm{sp} \mathrm{gr} \\
\text { 1.07. } 1 \text { - Operating, } 1 \text { - Spare }\end{array}$ & 15 & 30 \\
\hline 500 ST-30 & 1 & Tailings filter feed sump & Capacity 1000 gal & & \\
\hline 500 TK-01 & 1 & Tailings thickener tank & $\begin{array}{l}90 \mathrm{ft} \text { diameter thickener tank with } \\
\text { tunnel }\end{array}$ & & \\
\hline 500 TK-02 & 1 & Thickener overflow tank & Capacity 30,000 gal (concrete) & & \\
\hline 500 TM-01 & 1 & $\begin{array}{l}\text { Tailings thickener } \\
\text { mechanism }\end{array}$ & $\begin{array}{l}90 \mathrm{ft} \text { dia thickener mechanism with } \\
\text { controls }\end{array}$ & 15 & 15 \\
\hline 500 ZM-08 & 1 & $\begin{array}{l}\text { Flocculant storage,mixing } \\
\text { and dosing system }\end{array}$ & & 5 & 5 \\
\hline 600 AG-10 \& 11 & 2 & Coal additive mixer & Retention 5 min.: & 40 & 80 \\
\hline 600 AG-12 \& 13 & 2 & Slurry mixing tank agitator & & 40 & 80 \\
\hline 600 AG-14 thru 17 & 4 & $\begin{array}{l}\text { Slurry storage tank } \\
\text { agitator }\end{array}$ & & 75 & 300 \\
\hline 600 PP-78 \& 79 & 2 & CWF pump & $\begin{array}{l}\text { Horizontal slurry- Capacity-1500 } \\
\text { gpm, } 60 \mathrm{ft} \text { head, sp gr } 1.17\end{array}$ & 60 & 120 \\
\hline 600 PP-80 thru 83 & 4 & Slurry loading pump & $\begin{array}{l}\text { Horizontal slurry- Capacity-dry solids } \\
500 \mathrm{st} / \mathrm{h} \text { - slurry 3,000 gpm, } 60 \mathrm{ft} \\
\text { head, sp gr 1.17, 4-Operating and 4- } \\
\text { spare }\end{array}$ & 100 & 400 \\
\hline 600 ST-31 \& 32 & 2 & Slurry mixing tank & 10 min. each. Volume: & & \\
\hline
\end{tabular}


Table 6.2.1 (continued)

COMMERCIAL CWF PLANT- SELECTIVE AGGLOMERATION

Major Equipment List

\begin{tabular}{|c|c|c|c|c|c|}
\hline $\begin{array}{c}\text { Equipment } \\
\text { I.D }\end{array}$ & Qty & Title & Description & $\begin{array}{c}\text { Power (ea) } \\
\text { HP }\end{array}$ & $\begin{array}{c}\text { Total } \\
\text { installed } \\
\text { HP }\end{array}$ \\
\hline 600 ST-33 thru 36 & 4 & Slurry fuel storage tank & $\begin{array}{l}0.85 \text { million gal- } 55 \mathrm{ft} \text { dia and } 53 \mathrm{ft} \\
\text { high- total } 24 \mathrm{hr} .\end{array}$ & & \\
\hline 600 ZM-10 \& 11 & 2 & $\begin{array}{l}\text { Flocculant storage, } \\
\text { mixing and dosing system }\end{array}$ & & 10 & 20 \\
\hline
\end{tabular}


TABLE 6.2.2

PLANT 200: CRUSHING AND GRINDING

Material and Heat Balance

Quantities are total for all trains

\begin{tabular}{|c|c|c|c|c|c|c|c|c|c|}
\hline STREAM NO. & & 201 & 202 & 203 & 204 & 205 & 206 & 207 & 208 \\
\hline STREAM NAME & & RAW COAL & $\begin{array}{l}\text { DILUTION } \\
\text { WATER }\end{array}$ & $201+202$ & $\begin{array}{l}\text { BALL MILL } \\
\text { FEED }\end{array}$ & $\begin{array}{l}\text { MILL HEAT } \\
\text { RELEASE }\end{array}$ & $\begin{array}{l}\text { BALL MILL } \\
\text { DISCHARGE }\end{array}$ & $\begin{array}{l}\text { WATER TO } \\
\text { CYCLONE } \\
\text { FEED SUMP }\end{array}$ & $\begin{array}{l}\text { FEED TO } \\
\text { CYCLONE }\end{array}$ \\
\hline $\begin{array}{l}\text { SOLIDS (DRY) } \\
\text { WATER }\end{array}$ & $\begin{array}{l}\mathrm{lb} / \mathrm{h} \\
\mathrm{lb} / \mathrm{h}\end{array}$ & $\begin{array}{r}466,000 \\
37,784\end{array}$ & 605,740 & $\begin{array}{l}466,000 \\
643,524\end{array}$ & $\begin{array}{l}699,000 \\
876,524\end{array}$ & & $\begin{array}{l}699,000 \\
876,524\end{array}$ & $1,997,143$ & $\begin{array}{r}699,000 \\
2,873,667\end{array}$ \\
\hline STREAM TOTAL & $\mathrm{lb} / \mathrm{h}$ & 503,784 & 605,740 & $1,575,524$ & $1,575,524$ & & $1,575,524$ & $1,997,143$ & $3,572,667$ \\
\hline $\begin{array}{l}\text { SOLIDS (DRY) } \\
\text { WATER }\end{array}$ & $\begin{array}{l}\text { gpm } \\
\text { gpm }\end{array}$ & $\begin{array}{r}717 \\
76\end{array}$ & 1,211 & $\begin{array}{r}717 \\
1,287\end{array}$ & $\begin{array}{l}1,075 \\
1,646\end{array}$ & & $\begin{array}{r}998.6 \\
1,753.0\end{array}$ & $3,994.3$ & $\begin{array}{r}998.6 \\
5,747.3\end{array}$ \\
\hline STREAM TOTAL & gpm & 792 & 1,211 & 2,004 & 2,470 & & $2,751.6$ & $3,994.3$ & $6,745.9$ \\
\hline SOLIDS CONTENT & wt \% & 92.5 & & 42 & 44 & & 44 & & 20 \\
\hline $\begin{array}{l}\text { TEMPERATURE } \\
\text { PRESSURE }\end{array}$ & $\begin{array}{c}\operatorname{deg}{ }^{\circ} \mathrm{F} \\
\text { psia }\end{array}$ & $\begin{array}{r}70 \\
14.7\end{array}$ & $\begin{array}{r}70 \\
14.7\end{array}$ & $\begin{array}{r}70 \\
14.7\end{array}$ & $\begin{array}{r}70 \\
14.7\end{array}$ & & $\begin{array}{r}75 \\
14.7\end{array}$ & $\begin{array}{r}70 \\
14.7\end{array}$ & $\begin{array}{r}72 \\
14.7\end{array}$ \\
\hline ENTHALPY (rounded) & Btu/h & $6,748,000$ & $23,018,000$ & $29,766,000$ & $41,831,000$ & $5,091,000$ & $46,922,000$ & $75,891,000$ & $122,814,000$ \\
\hline
\end{tabular}

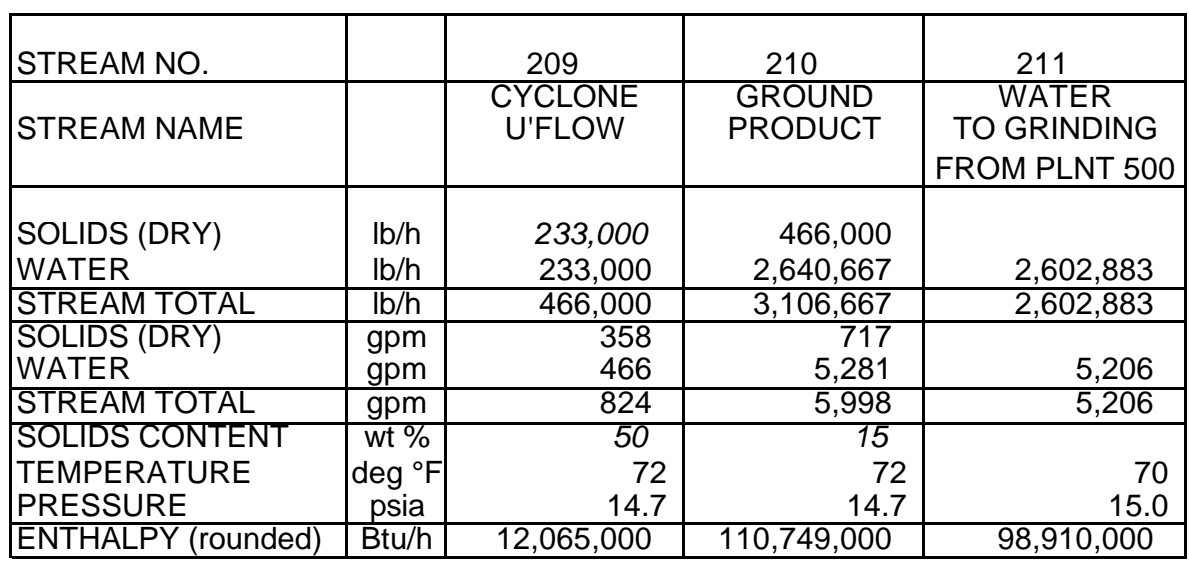


Table 6.2.3
PLANT 350: SELECTIVE AGGLOMERATION

Material and Heat Balance

antitios are total for all trains

Note 2. Later tests indicate that spary to be $1800 \mathrm{gpm}$ for better results

\begin{tabular}{|c|c|c|c|c|c|c|c|c|c|c|c|c|c|}
\hline STREAM NO. & & 301 & 302 & 303 & $303 \mathrm{~A}$ & 304 & 305 & $305 \mathrm{~A}$ & 306 & 307 & $\begin{array}{l}307 \mathrm{~A} \\
\text { (NOTE 2) }\end{array}$ & 308 & 309 \\
\hline STREAM NAME & & $\begin{array}{l}\text { AGGLOME- } \\
\text { RATION } \\
\text { FEED }\end{array}$ & $\begin{array}{c}\text { BRIDGING } \\
\text { LIQUID }\end{array}$ & $\begin{array}{c}\text { MIXED FEED } \\
\text { TO AGGLOME- } \\
\text { RATION }\end{array}$ & $\begin{array}{c}\text { HEAT OF } \\
\text { HSR } \\
\text { MIXER } \\
\left({ }^{*}\right)\end{array}$ & $\begin{array}{c}\text { HSR } \\
\text { DISCHARGE }\end{array}$ & $\begin{array}{l}\text { DILUTION } \\
\text { WATER }\end{array}$ & $\begin{array}{c}\text { HEAT OF } \\
\text { LSR } \\
\text { MIXER } \\
\left({ }^{* *}\right)\end{array}$ & $\begin{array}{c}\text { LSR } \\
\text { DISCHARGE }\end{array}$ & $\begin{array}{l}\text { SCREEN } \\
\text { SPRAY } \\
\text { WATER }\end{array}$ & $\begin{array}{l}\text { TOTAL } \\
\text { SCREEN } \\
\text { FEED }\end{array}$ & TAILINGS & $\begin{array}{c}\text { AGGLO- } \\
\text { MERATES \& } \\
\text { BRIG. LIQD. }\end{array}$ \\
\hline $\begin{array}{l}\text { SOLIDS (DRY) } \\
\text { WATER } \\
\text { HEPTANE } \\
\text { STEAM } \\
\text { HEPTANE- VAPOR }\end{array}$ & $\begin{array}{l}\mathrm{l} b / h r \\
\mathrm{lb} / \mathrm{hr} \\
\mathrm{lb} / \mathrm{hr} \\
\mathrm{l} / \mathrm{hr} \\
\mathrm{lb} / \mathrm{hr}\end{array}$ & $\begin{array}{r}466,000 \\
2,640,667\end{array}$ & 116,384 & $\begin{array}{r}466,000 \\
2,640,667 \\
116,384\end{array}$ & & $\begin{array}{r}466,000 \\
2,640,667 \\
116,384\end{array}$ & $1,436,943$ & & $\begin{array}{r}466,000 \\
4,077,610 \\
116,384\end{array}$ & 250,000 & $\begin{array}{r}466,000 \\
4,327,610 \\
116,384\end{array}$ & $\begin{array}{r}32,620 \\
4,010,614\end{array}$ & $\begin{array}{l}433,380 \\
316,997 \\
116,384\end{array}$ \\
\hline TOTAL STREAM & $\mathrm{lb} / \mathrm{hr}$ & $3,106,667$ & 116,384 & $3,223,050$ & & $3,223,050$ & $1,436,943$ & & $4,659,994$ & 250,000 & $4,909,994$ & $4,043,234$ & 866,7 \\
\hline SOLIDS (DRY) & $g p$ & $\begin{array}{r}717 \\
5281\end{array}$ & 340 & $\begin{array}{r}717 \\
5621\end{array}$ & & $\begin{array}{r}717 \\
5621\end{array}$ & 2874 & & $\begin{array}{r}717 \\
8495\end{array}$ & 500 & $\begin{array}{r}717 \\
8095\end{array}$ & $\begin{array}{r}50 \\
8021\end{array}$ & \\
\hline FLOW & & $\mid \begin{array}{l}\mid, 281 \\
5,998\end{array}$ & $\frac{340}{340}$ & $\frac{\frac{3,621}{6,338}}{1}$ & & $\frac{3,621}{6,338}$ & $\frac{2,8 / 4}{2,874}$ & & \begin{tabular}{|l|}
9,212 \\
9,212
\end{tabular} & 500 & $\begin{array}{l}8,955 \\
9,712 \\
\end{array}$ & $\frac{8,021}{8,071}$ & $\begin{array}{r}974 \\
1,641\end{array}$ \\
\hline CONTENT & $\frac{g p m}{w t} \%$ & $\frac{150}{15}$ & & $\begin{aligned}, 500 \\
14\end{aligned}$ & & 14 & & & \begin{tabular}{|l|}
, 215 \\
10
\end{tabular} & & & & $\begin{array}{r}\frac{1,641}{50} \\
70\end{array}$ \\
\hline TEMP & ${ }^{\circ} \mathrm{F}$ & 72 & 80 & 72 & & 73 & 70 & & 72 & 70 & 72 & 72 & \\
\hline PRESSURE & psia & 15 & & & & & 15 & & 15 & 15 & 15 & 15 & \\
\hline ENTHALPY (rounded) & Btu/h & $110,749,000$ & $2,950,000$ & $113,698,000$ & $2,484,000$ & $116,183,000$ & $54,604,000$ & $59 \mathrm{c}$ & $171,385,000$ & $9,500,000$ & $180,885,000$ & $160,577,000$ & $20,308,000$ \\
\hline
\end{tabular}

\begin{tabular}{|c|c|c|c|c|c|c|c|c|c|c|c|c|c|}
\hline & & & & & & actor power $\mathrm{kW}$ & 2912.5 & 702 & $\%$ to slurry & 25 & 25 & & \\
\hline STREAM NO. & & 310 & 311 & 312 & 313 & 314 & 315 & 316 & 317 & 318 & 319 & 320 & 321 \\
\hline STREAM NAME & & $\begin{array}{c}\text { CLARIFIED } \\
\text { WATER HEATER } \\
\text { INLET }\end{array}$ & $\begin{array}{l}\text { HEATED } \\
\text { CLARIFIED } \\
\text { WATER }\end{array}$ & $\begin{array}{c}\text { FEED TO } \\
\text { STEAM } \\
\text { STRIPPER-A }\end{array}$ & $\begin{array}{c}\text { FLOW } \\
\text { FROM } \\
\text { STEAM } \\
\text { STRIPPER-B }\end{array}$ & $\begin{array}{c}\text { FEED TO } \\
\text { STEAM } \\
\text { STRIPPER-B }\end{array}$ & STEAM & $\begin{array}{c}\text { VAPOR TO } \\
\text { TO } \\
\text { AIR COOLER }\end{array}$ & $\begin{array}{l}\text { LIQUID FROM } \\
\text { AIR } \\
\text { COOLER }\end{array}$ & \begin{tabular}{c|} 
COOLED \\
CONDENSATE
\end{tabular} & \begin{tabular}{|c|} 
SLURRY TO \\
WATER \\
PREHEATER
\end{tabular} & \begin{tabular}{|c|} 
SLURRY \\
FROM \\
WATER \\
PREHEATER \\
\end{tabular} & $\begin{array}{l}\text { COOLED } \\
\text { CLEAN } \\
\text { COAL } \\
\text { SLURRY } \\
\end{array}$ \\
\hline $\begin{array}{l}\text { SOLIDS (DRY) } \\
\text { WATER } \\
\text { HEPTANE } \\
\text { STEAM } \\
\text { HEPTANE- VAPOR }\end{array}$ & $\begin{array}{l}\mathrm{lb} / \mathrm{hr} \\
\mathrm{lb} / \mathrm{hr} \\
\mathrm{l} / \mathrm{hr} \\
\mathrm{lb} / \mathrm{hr} \\
\mathrm{l} / \mathrm{hr}\end{array}$ & 584,835 & 584,835 & $\begin{array}{l}433,380 \\
901,831 \\
116,384\end{array}$ & 190,857 & $\begin{array}{r}433,380 \\
1,011,220\end{array}$ & 214,000 & $\begin{array}{r}\mathbf{8 1}, \mathbf{4 6 8} \\
116,384\end{array}$ & $\begin{array}{r}81,468 \\
116,384\end{array}$ & $\begin{array}{r}81,468 \\
116,384\end{array}$ & $\begin{array}{r}433,380 \\
1,034,363\end{array}$ & $\begin{array}{r}433,380 \\
1,034,363\end{array}$ & $\begin{array}{r}433,380 \\
1,034,363\end{array}$ \\
\hline TOTAL STREAM & $\mathrm{lb} / \mathrm{hr}$ & 584,835 & 584,835 & $1,451,595$ & 190,857 & $1,444,600$ & 214,000 & 197,852 & 197,852 & 197,852 & $1,467,743$ & $1,467,743$ & $1,467,743$ \\
\hline $\begin{array}{l}\text { SOLIDS (DRY) } \\
\text { LIQUID }\end{array}$ & $\begin{array}{l}\text { gpm } \\
\text { gpm }\end{array}$ & 1,170 & 1,170 & $\begin{array}{r}667 \\
2,143\end{array}$ & & $\begin{array}{r}667 \\
2,022 \\
\end{array}$ & & & 503 & 503 & $\begin{array}{r}667 \\
2,069\end{array}$ & $\begin{array}{r}667 \\
2,069\end{array}$ & $\begin{array}{r}667 \\
2,069 \\
\end{array}$ \\
\hline TOTAL STREAM & $\mathrm{gpm}$ & 1,170 & 1,170 & 2,810 & & 2,689 & & & 503 & 503 & 2,735 & 2,735 & $\begin{array}{l}2,005 \\
2,735 \\
2,0\end{array}$ \\
\hline $\begin{array}{l}\text { SOLIDS CONTENT } \\
\text { TEMPERATURE }\end{array}$ & $\begin{array}{c}\text { wt \% } \\
{ }^{2} \mathrm{~F}\end{array}$ & 72 & 190 & $\begin{array}{r}30 \\
135\end{array}$ & 240 & $\begin{array}{r}30 \\
220\end{array}$ & 256 & 224 & 140 & 80 & $\begin{array}{r}30 \\
240\end{array}$ & $\begin{array}{r}30 \\
177\end{array}$ & $\begin{array}{l}30 \\
80\end{array}$ \\
\hline $\begin{array}{l}\text { PRESSURE } \\
\text { PRE }\end{array}$ & psia & $\begin{array}{r}20 \\
\end{array}$ & $\begin{array}{r}15 \\
\end{array}$ & $\begin{array}{r}18 \\
\end{array}$ & $\begin{array}{r}240 \\
\end{array}$ & $\begin{array}{r}25 \\
\end{array}$ & $\begin{array}{r}33 \\
\end{array}$ & $\begin{array}{r}24 \\
19 \\
\end{array}$ & $\begin{array}{r}17 \\
\end{array}$ & $\begin{array}{r}17 \\
\end{array}$ & $\begin{array}{r}240 \\
45 \\
\end{array}$ & $\begin{array}{r}40 \\
\end{array}$ & $\begin{array}{r}30 \\
35 \\
\end{array}$ \\
\hline ENTHALPY (rounded) & Btu/h & $23,295,000$ & $92,404,000$ & $112,712,000$ & $221,509,000$ & $214,229,000$ & $249,470,000$ & $119,992,000$ & $15,636,000$ & $6,860,000$ & $242,190,000$ & \begin{tabular}{|l|l|}
$173,081,000$ \\
\end{tabular} & $55,890,000$ \\
\hline
\end{tabular}

\begin{tabular}{|c|c|c|c|c|c|c|c|c|c|c|}
\hline STREAM NO. & & 322 & 323 & 324 & 325 & 326 & 327 & 328 & 329 & 330 TO 350 \\
\hline STREAM NAME & & $\begin{array}{c}\text { CHILLED WATER } \\
\text { AT CONDENSATE } \\
\text { COOLER } \\
\text { INLET }\end{array}$ & $\begin{array}{l}\text { CW AT } \\
\text { CONDENSATE } \\
\text { COOLER } \\
\text { OUT LET }\end{array}$ & $\begin{array}{l}\text { CWAT } \\
\text { SLURRY } \\
\text { COOLER } \\
\text { INLET }\end{array}$ & $\begin{array}{l}\text { CWAT } \\
\text { SLURRY } \\
\text { COOLER } \\
\text { OUT LET }\end{array}$ & $\begin{array}{c}\text { WATER } \\
\text { CONDENSED }\end{array}$ & $\begin{array}{l}\text { CONDENSED } \\
\text { HEPTANE } \\
\text { LIQUID }\end{array}$ & $\begin{array}{c}\text { MAKE-UP } \\
\text { BOILER } \\
\text { FEED WATER }\end{array}$ & $\begin{array}{c}\text { HEAT OUTPUT } \\
\text { OF BOILER } \\
\text { (ENTHALPY IN- } \\
\text { CREASE OF FW) }\end{array}$ & $\begin{array}{l}\text { STREAM } \\
\text { NUMBERS } \\
\text { NOT USED }\end{array}$ \\
\hline $\begin{array}{l}\text { SOLIDS (DRY) } \\
\text { ASPHALT } \\
\text { WATER } \\
\text { HEPTANE } \\
\text { STEAM } \\
\text { HEPTANE- VAPOR }\end{array}$ & $\begin{array}{l}\mathrm{l} \mathrm{b} / \mathrm{hr} \\
\mathrm{lb} / \mathrm{hr} \\
\mathrm{l} / \mathrm{hr} \\
\mathrm{l} / \mathrm{hr} \\
\mathrm{l} / \mathrm{b} / \mathrm{h} \\
\mathrm{lb} / \mathrm{hr}\end{array}$ & 135,008 & 135,008 & $2,604,243$ & $2,604,243$ & 81,468 & 116,384 & 132,532 & & \\
\hline TOTAL STREAM & $\mathrm{lb} / \mathrm{hr}$ & 135,008 & 135,008 & $2,604,243$ & $2,604,243$ & 81,468 & 116,384 & 132,532 & & \\
\hline $\begin{array}{l}\text { SOLIDS (DRY) } \\
\text { LIQUID }\end{array}$ & $\begin{array}{l}\text { gpm } \\
\text { gpm }\end{array}$ & 270 & 270 & 5,208 & 5,208 & 163 & 340 & 265 & & \\
\hline $\begin{array}{l}\text { LQUUD } \\
\text { TOTAL STREAM }\end{array}$ & $\frac{\mathrm{gpm}}{\mathrm{gpm}}$ & 270 & $\frac{270}{270}$ & \begin{tabular}{|l|}
, 200 \\
5,208
\end{tabular} & $\begin{array}{l}\frac{5,208}{5,208} \\
-\end{array}$ & 163 & 340 & 265 & & \\
\hline TEMPERATURE & ${ }^{\circ} \mathrm{F}$ & 50 & 115 & 70 & 115 & 80 & 80 & 70 & & \\
\hline PRESSURE & psia & 25 & 20 & 25 & 20 & 17 & 17 & 20 & & \\
\hline ENTHALPY (rounded) & Btu/h & $2,430,000$ & $11,206,000$ & $98,961,000$ & $216,152,000$ & $3,910,000$ & $2,950,000$ & $5,036,000$ & $240,524,000$ & \\
\hline
\end{tabular}


Table 6.2.3 (Continued)

PLANT 350: SELECTIVE AGGLOMERATION

Material and Heat Balance

\begin{tabular}{|c|c|c|c|c|c|c|c|c|c|}
\hline STREAM NO. & & 351 & 352 & 353 & 354 & 355 & 356 & 357 & 358 \\
\hline STREAM NAME & & $\begin{array}{c}\text { CW RETURN } \\
\text { TO } \\
\text { CW POND }\end{array}$ & $\begin{array}{l}\text { WATER FROM } \\
\text { CW POND }\end{array}$ & $\begin{array}{l}\text { POND WATER } \\
\text { TO CHILLER } \\
\text { DRUM }\end{array}$ & $\begin{array}{l}\text { WATER TO } \\
\text { CHILLER }\end{array}$ & $\begin{array}{l}\text { WATER } \\
\text { FROM } \\
\text { CHILLER }\end{array}$ & $\begin{array}{c}\text { CHILLED } \\
\text { WATER-1N } \\
\text { RECY WTR CLR }\end{array}$ & $\begin{array}{l}\text { CHILLED WATER } \\
\text { TO BLNKT GAS } \\
\text { COOLER }\end{array}$ & \begin{tabular}{|l|} 
CW RETURN \\
FROM BLNKT \\
GAS COOLER \\
\end{tabular} \\
\hline $\begin{array}{l}\text { SOLIDS (DRY) } \\
\text { WATER } \\
\text { STREAMTOTI }\end{array}$ & $\begin{array}{l}\mathrm{b} / \mathrm{h} / \mathrm{h} \\
\mathrm{b} / \mathrm{h}\end{array}$ & $\begin{array}{l}2,739,252 \\
2739252\end{array}$ & \begin{tabular}{r|}
$2,739,252$ \\
2739252
\end{tabular} & \begin{tabular}{|l|}
135,008 \\
135008
\end{tabular} & $\begin{array}{l}1,549,256 \\
11549256\end{array}$ & $1,549,256$ & \begin{tabular}{r|r|}
$1,264,248$ \\
124,248
\end{tabular} & $\begin{array}{l}150,000 \\
150,000\end{array}$ & $\begin{array}{r}150,000 \\
150,000\end{array}$ \\
\hline $\begin{array}{l}\text { STREAM TOTAL } \\
\text { SOLIDS (DRY) }\end{array}$ & $\frac{\mathrm{lb} / \mathrm{h}}{\mathrm{gpm}}$ & & & & & & & & \\
\hline WATER & $\mathrm{gpm}$ & 5,479 & 5,479 & 270 & 3,099 & 3,099 & 2,528 & 300 & 300 \\
\hline TOTAL FLOW & $\mathrm{gpm}$ & 5,479 & 5,479 & 270 & 3,099 & 3,099 & 2,528 & 300 & 300 \\
\hline $\begin{array}{l}\text { SOLIDS CONTENT } \\
\text { TEMPERATURE }\end{array}$ & $\begin{array}{l}\mathrm{wt} \% \\
\mathrm{deg}^{\circ} \mathrm{F}\end{array}$ & 115 & 70 & $\begin{array}{r}70 \\
15\end{array}$ & 60.9 & 50 & 50 & 50 & $\begin{array}{r}60 \\
15 \\
-15\end{array}$ \\
\hline ENTHALPY (round off) & $\frac{\mid p_{s i d}}{\mathrm{Btu} / \mathrm{h}}$ & 227,358,000 & $\begin{array}{l}104,092,000 \\
\end{array}$ & $\begin{array}{r}15 \\
5,130,000\end{array}$ & 44,729,000 & $\begin{array}{r}60 \\
27,887,000 \\
\end{array}$ & $\begin{array}{r}25 \\
22,756,000\end{array}$ & $\begin{array}{r}5,700,000 \\
\end{array}$ & $\begin{array}{r}15,200,000 \\
4\end{array}$ \\
\hline
\end{tabular}


Table 6.2.4

PLANT 400: CLEAN COAL DEWATERING

Material and Heat Balance

Quantities are total for all trains

\begin{tabular}{|c|c|c|c|c|}
\hline SI KEAIVI NU. & & 401 & 402 & 403 \\
\hline STREAM NAME & & $\begin{array}{l}\text { CLEAN } \\
\text { COAL } \\
\text { SLURRY }\end{array}$ & $\begin{array}{c}\text { CLEAN } \\
\text { COAL } \\
\text { FILTER CAKE }\end{array}$ & $\begin{array}{l}\text { CLEAN } \\
\text { COAL } \\
\text { FILTRATE }\end{array}$ \\
\hline SOLIDS (DRY) & $\mathrm{lb} / \mathrm{h}$ & 433,380 & 433,380 & \\
\hline WATER & $\mathrm{lb} / \mathrm{h}$ & $1,034,363$ & 254,525 & 779,838 \\
\hline STREAM TOTAL & $\mathrm{lb} / \mathrm{h}$ & $1,467,743$ & 687,905 & 779,838 \\
\hline SOLIDS (DRY) & $\mathrm{gpm}$ & 667 & 667 & \\
\hline WATER & $\mathrm{gpm}$ & 2,069 & 509 & 1,560 \\
\hline STREAM TOTAL & $\mathrm{gpm}$ & 2,735 & 1,176 & 1,560 \\
\hline SOLIDS CONTENT & wt \% & 30 & 63 & \\
\hline TEMPERATURE & $\operatorname{deg}{ }^{\circ} \mathrm{F}$ & 80 & 80 & 80 \\
\hline PRESSURE & psia & 15 & 15 & 15 \\
\hline ENTHALPY (rounded) & Btu/h & $55,890,000$ & $18,458,000$ & $37,432,000$ \\
\hline
\end{tabular}


Table 6.2 .5
PLANT 500: WATER CLARIFICATION AND TAILINGS HANDLING

Material and Heat Balance

\begin{tabular}{|c|c|c|c|c|c|c|c|c|c|c|c|}
\hline STREAM NO. & & 501 & 502 & 503 & $503 \mathrm{~A}$ & 504 & 505 & 506 & 507 & 508 & 509 \\
\hline STREAM NAME & & TAILINGS & $\begin{array}{l}\text { TAILINGS } \\
\text { FILTRATE }\end{array}$ & $\begin{array}{c}\text { THICKENER } \\
\text { FEED }\end{array}$ & $\begin{array}{l}\text { HEAT LOSS } \\
\text { IN } \\
\text { THICKENER } \\
\end{array}$ & $\begin{array}{l}\text { THICKENER } \\
\text { UNDERFLOW }\end{array}$ & $\begin{array}{l}\text { THICKENER } \\
\text { OVERFLOW }\end{array}$ & $\begin{array}{l}\text { TAILINGS } \\
\text { CAKE }\end{array}$ & $\begin{array}{c}\text { CLARIFIED } \\
\text { WATER } \\
\text { TO PLANT } 600 \\
\end{array}$ & $\begin{array}{l}\text { UTILITY WATER } \\
\text { TO THICKENER } \\
\text { O'FLOW TANK } \\
\end{array}$ & $\begin{array}{l}\text { THICKENER } \\
\text { OVERFLOW + } \\
\text { STREAM 508 }\end{array}$ \\
\hline $\begin{array}{l}\text { SOLIDS (DRY) } \\
\text { WATER } \\
\text { STREAM TOTAL }\end{array}$ & $\begin{array}{l}\mathrm{lb} / \mathrm{h} \\
\mathrm{l} / \mathrm{b} / \mathrm{h} \\
\mathrm{lb} / \mathrm{h}\end{array}$ & $\begin{array}{r}32,620 \\
4,010,614 \\
4,043,234\end{array}$ & $\begin{array}{l}69,900 \\
69,900\end{array}$ & $\begin{array}{r}32,620 \\
4,860,352 \\
4,892,972\end{array}$ & (assumed) & $\begin{array}{r}32,620 \\
130,480 \\
163,100\end{array}$ & $\begin{array}{r}4,729,872 \\
4,729,872\end{array}$ & $\begin{array}{l}32,620 \\
60,580 \\
93,200\end{array}$ & $\frac{35,840}{35,840}$ & $\begin{array}{l}180,629 \\
180,629\end{array}$ & $\begin{array}{l}4,910,501 \\
4,910,501\end{array}$ \\
\hline SOLIDS (DRY) & gpm & $\begin{array}{r}4,040,204 \\
50\end{array}$ & & $\begin{array}{r}4,00,512 \\
50\end{array}$ & & 50 & & 50 & & & \\
\hline WATER & $\mathrm{gpm}$ & 8,021 & 140 & 9,721 & & 261 & 9,460 & 121 & 72 & 361 & 9,821 \\
\hline STREAM TOTAL & $\mathrm{gpm}$ & 8,071 & 140 & 9,771 & & 311 & 9,460 & 171 & 72 & 361 & 9,821 \\
\hline SOLIDS CONTENT & wt $\%$ & 0.81 & & 0.67 & & 20 & & 35 & & & \\
\hline TEMPERATURE & & & 73 & 73 & & 73 & 73 & 73 & 73 & 70 & 73 \\
\hline PRESSURE & psia & $\begin{array}{r}14 . \overline{7} \\
00.777\end{array}$ & $\begin{array}{r}15 \\
\end{array}$ & $\begin{array}{r}15 \\
0000000\end{array}$ & & $\begin{array}{r}20 \\
5780000\end{array}$ & $\begin{array}{r}12 \\
01007020\end{array}$ & $\begin{array}{r}12 \\
\end{array}$ & 45 & $\begin{array}{r}12 \\
\end{array}$ & $\begin{array}{r}60 \\
\end{array}$ \\
\hline ENTHALPY (rounded) & Btu/h & $160,577,000$ & $2,883,000$ & $200,893,000$ & 900,000 & $5,786,000$ & $194,207,000$ & $2,903,000$ & $1,468,000$ & $6,863,912$ & $201,070,697$ \\
\hline
\end{tabular}

\begin{tabular}{|c|c|c|c|c|c|c|c|c|c|c|c|}
\hline STREAM NO. & & 510 & 511 & 512 & 513 & 514 & $514 \mathrm{~A}$ & 515 & 516 & 517 & 518 \\
\hline STREAM NAME & & $\begin{array}{l}\text { CLARIFIED } \\
\text { WATER TO } \\
350-E-120 \\
\text { THRU } 129 \\
\end{array}$ & $\begin{array}{c}\text { RECYCLE } \\
\text { WATER } \\
\text { COOLER } \\
\text { INLET } \\
\end{array}$ & $\begin{array}{c}\text { RECYCLE } \\
\text { WATER } \\
\text { COOLER } \\
\text { OUTLET } \\
\end{array}$ & $\begin{array}{c}\text { CLARIFIED } \\
\text { WATER TO } \\
\text { LSR \& SCREEN }\end{array}$ & $\begin{array}{l}\text { CLARIFIED } \\
\text { WATER TO } \\
\text { PLANT } 200\end{array}$ & $\begin{array}{l}\text { RECYCLE } \\
\text { WATER } \\
\text { COOLER } \\
\text { HEAT LOAD }\end{array}$ & $\begin{array}{l}\text { CHILLED } \\
\text { WATER-1N } \\
\text { RECYCLE } \\
\text { WATER CLR }\end{array}$ & $\begin{array}{l}\text { COOLING } \\
\text { WATER-OUT } \\
\text { RECYCLE } \\
\text { WATER CLR } \\
\end{array}$ & $\begin{array}{c}\text { TOTAL } \\
\text { PLANT } \\
\text { MAKE-UP } \\
\text { WATER } \\
\end{array}$ & $\begin{array}{c}\text { BOILER } \\
\text { FEED WATER } \\
\text { MAKE-UP }\end{array}$ \\
\hline $\begin{array}{l}\text { SOLIDS (DRY) } \\
\text { WATER }\end{array}$ & $\begin{array}{l}\mathrm{lb} / \mathrm{h} \\
\mathrm{lb} / \mathrm{h}\end{array}$ & 584.835 & $4,289,826$ & $4,289,826$ & $1,686.943$ & $2,602,883$ & & $1,264,248$ & $1,264,248$ & 313,161 & 132,532 \\
\hline STREAM TOTAL & $\mathrm{lb} / \mathrm{h}$ & 584,835 & $4,289,826$ & $4,289,826$ & $1,686,943$ & $2,602,883$ & & $1,264,248$ & $1,264,248$ & 313,161 & 132,532 \\
\hline $\begin{array}{l}\text { SOLIDS (DRY) } \\
\text { WATER }\end{array}$ & $\begin{array}{l}\text { gpm } \\
\text { gpm }\end{array}$ & & 8,580 & 8.580 & & 5,206 & & 2.528 & 2528 & & 265 \\
\hline $\begin{array}{l}\text { WATER } \\
\text { STREAM TOTAL }\end{array}$ & $\begin{array}{l}\text { gpm } \\
\mathrm{gpm}\end{array}$ & $\frac{1,110}{1,170}$ & 8,580 & $\frac{8,580}{8,580}$ & $\begin{array}{l}3,3 / 4 \\
3,374\end{array}$ & $\frac{5,206}{5,206}$ & & $\frac{2,528}{2,528}$ & $\frac{2,528}{2,528}$ & $\frac{626}{626}$ & $\frac{265}{265}$ \\
\hline $\begin{array}{l}\text { SOLIDS CONTENT } \\
\text { TEMPERATURE } \\
\text { PKLSSURE }\end{array}$ & \begin{tabular}{|c|} 
wt \% \\
deg $^{\circ} \mathrm{F}$ \\
psia
\end{tabular} & $\begin{array}{l}73 \\
45 \\
\end{array}$ & $\begin{array}{r}73 \\
45 \\
\end{array}$ & $\begin{array}{l}70 \\
45 \\
\end{array}$ & $\begin{array}{l}70 \\
50\end{array}$ & $\begin{array}{l}70 \\
50\end{array}$ & & $\begin{array}{l}50 \\
25\end{array}$ & $\begin{array}{l}60 \\
15 \\
\end{array}$ & $\begin{array}{l}70 \\
15 \\
\end{array}$ & $\begin{array}{l}70 \\
20 \\
\end{array}$ \\
\hline ENTHALPY (rounded & & 23.947000 & $175,656.000$ & $163,013,000$ & 64104000 & $98,910,000$ & 12 & $22,756,000$ & $35,399$. & 11900 & $5,036,000$ \\
\hline
\end{tabular}


Table 6.2.6

PLANT 600: CWF PREPARATION AND LOADING

Material and Heat Balance

Note: Quantities are total for two trains

\begin{tabular}{|c|c|c|c|c|c|c|c|c|c|}
\hline STREAM NO. & & 601 & 602 & 603 & 604 & 605 & 606 & 607 & 608 \\
\hline STREAM NAME & & $\begin{array}{c}\text { DEWATERED } \\
\text { CLEAN } \\
\text { COAL }\end{array}$ & $\begin{array}{c}\text { CLARIFIED } \\
\text { WATER } \\
\text { TO } \\
\text { PLANT } 600\end{array}$ & $\begin{array}{l}\text { PREMIUM } \\
\text { FUEL } \\
\text { (CWF) }\end{array}$ & $\begin{array}{c}\text { SOLID } \\
\text { ADDITIVE }\end{array}$ & $\begin{array}{l}\text { WATER } \\
\text { IN } \\
\text { ADDITIVE } \\
\text { MIXTURE }\end{array}$ & $\begin{array}{l}\text { ADDITIVE } \\
\text { MIXTURE }\end{array}$ & $\begin{array}{c}\text { FEED TO } \\
\text { MIXERS }\end{array}$ & $\begin{array}{c}\text { WATER FOR } \\
\text { FINAL } \\
\text { ADJUSTMENT }\end{array}$ \\
\hline SOLIDS (DRY) & $\mathrm{Ib} / \mathrm{h}$ & 433,380 & & 433,380 & & & & 433,380 & \\
\hline SOLID ADDITIVE & $\mathrm{lb} / \mathrm{h}$ & & & 2,167 & 2,167 & & 2,167 & 2,167 & \\
\hline WATER & $\mathrm{lb} / \mathrm{h}$ & 254,525 & 35,840 & 290,365 & & 2,648 & 2,648 & 257,173 & 33,191 \\
\hline STREAM TOTAL & $\mathrm{Ib} / \mathrm{h}$ & 687,905 & 35,840 & 725,912 & 2,167 & 2,648 & 4,815 & 692,720 & 33,191 \\
\hline SOLIDS (DRY) & gpm & 667 & & 667 & 3 & & 3 & 667 & \\
\hline WATER & gpm & 509 & 72 & 581 & & 5 & 5 & 514 & 66 \\
\hline STREAM TOTAL & $\mathrm{gpm}$ & 1,176 & 72 & 1,247 & 3 & 5 & 8 & 1,181 & 66 \\
\hline SOLIDS CONTENT & wt $\%$ & 63 & & 60 & & & 45 & 63 & \\
\hline TEMPERATURE & ${ }^{\circ} \mathrm{F}$ & 80 & 73 & 79 & 70 & 73 & 72 & 83 & 39 \\
\hline PRESSURE & psia & 15 & 15 & 15 & 15 & 15 & 15 & 15 & 15 \\
\hline ENTHALPY & $\mathrm{Btu} / \mathrm{h}$ & $18,457,861$ & $1,467,537$ & $19,950,100$ & 24,703 & 108,446 & 133,148 & $19,708,506$ & 241,594 \\
\hline ENTHALPY (rounded) & Btu/h & $18,458,000$ & $1,468,000$ & $19,950,000$ & 25,000 & 108,000 & 133,000 & $19,708,000$ & 242,000 \\
\hline
\end{tabular}









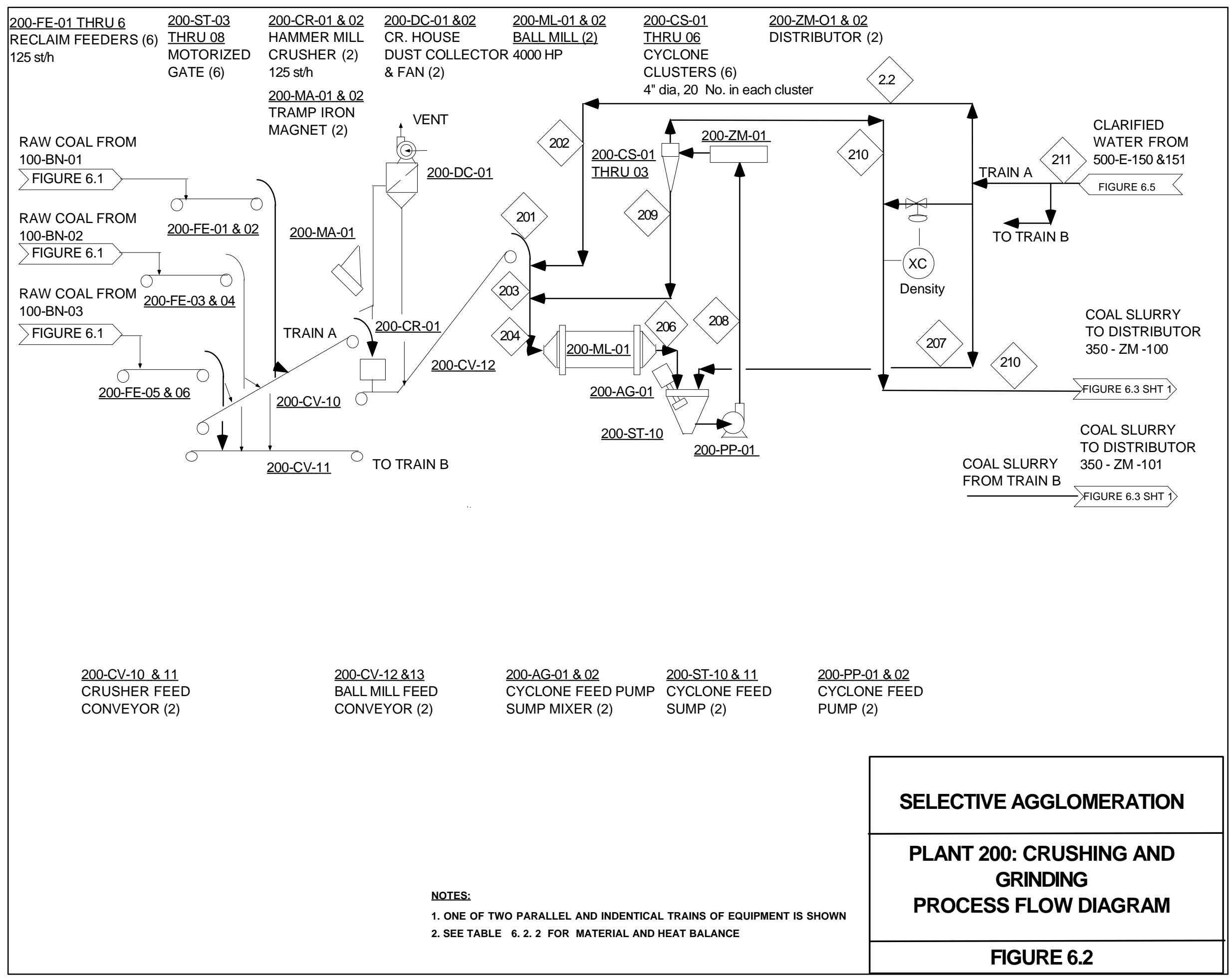




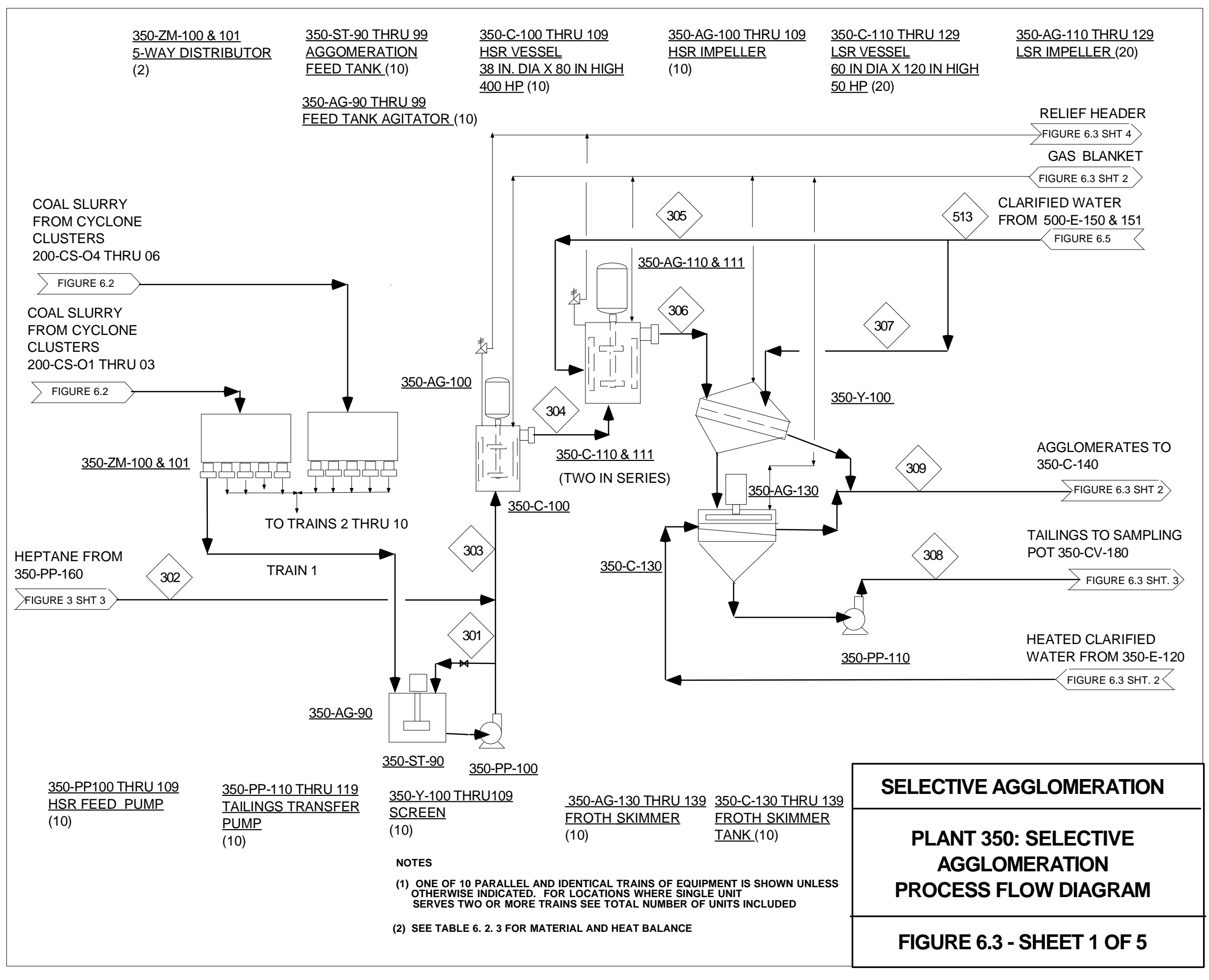




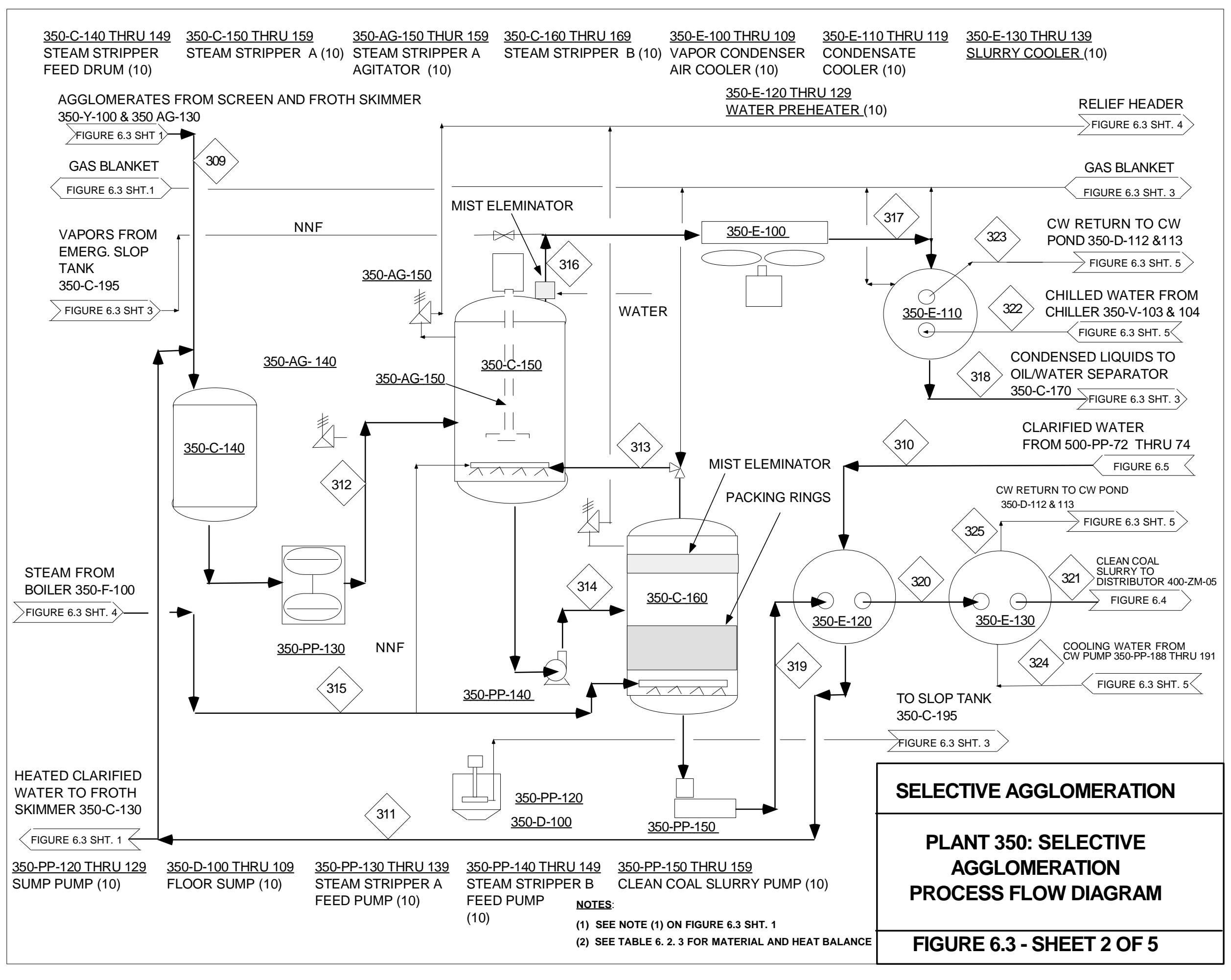




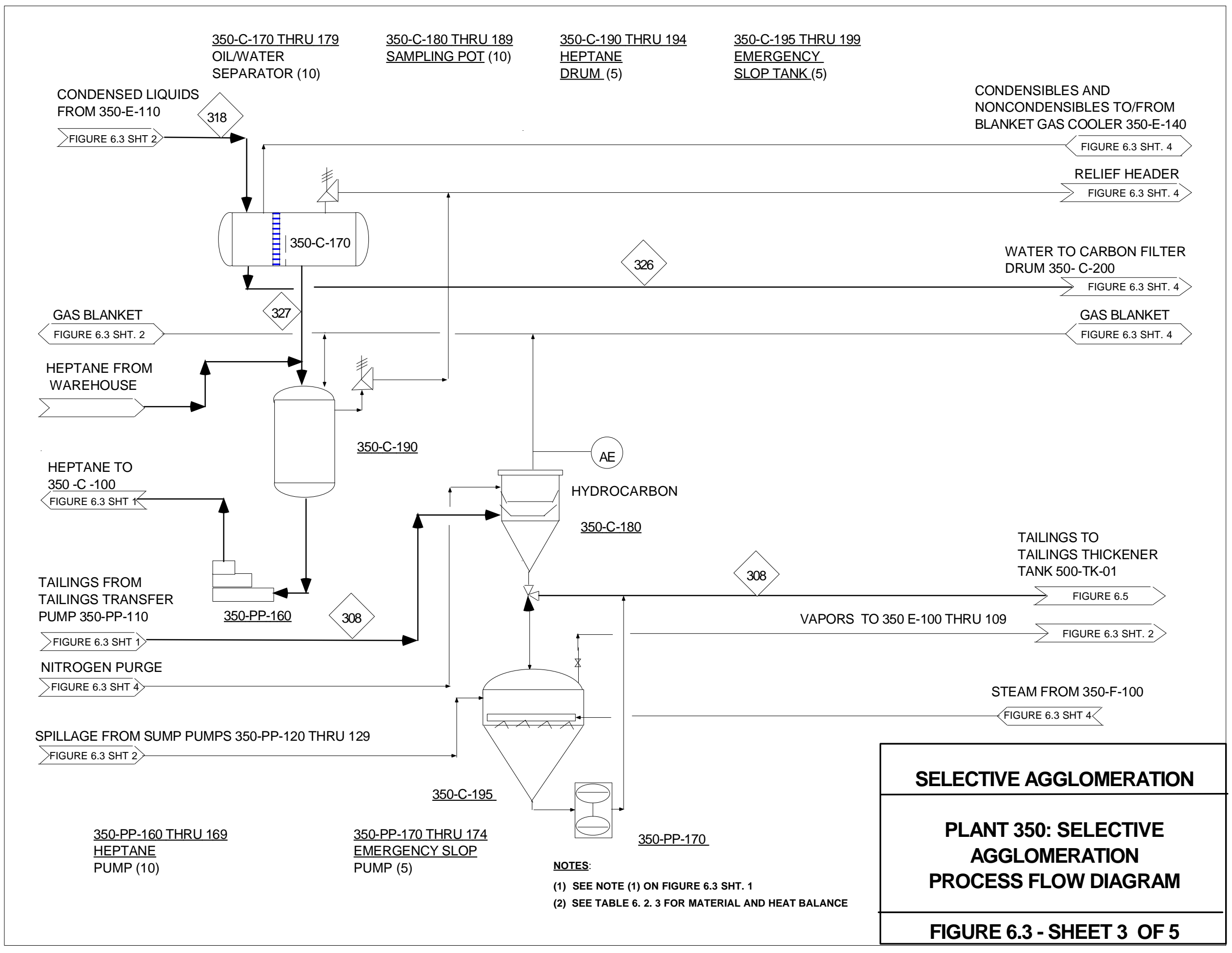




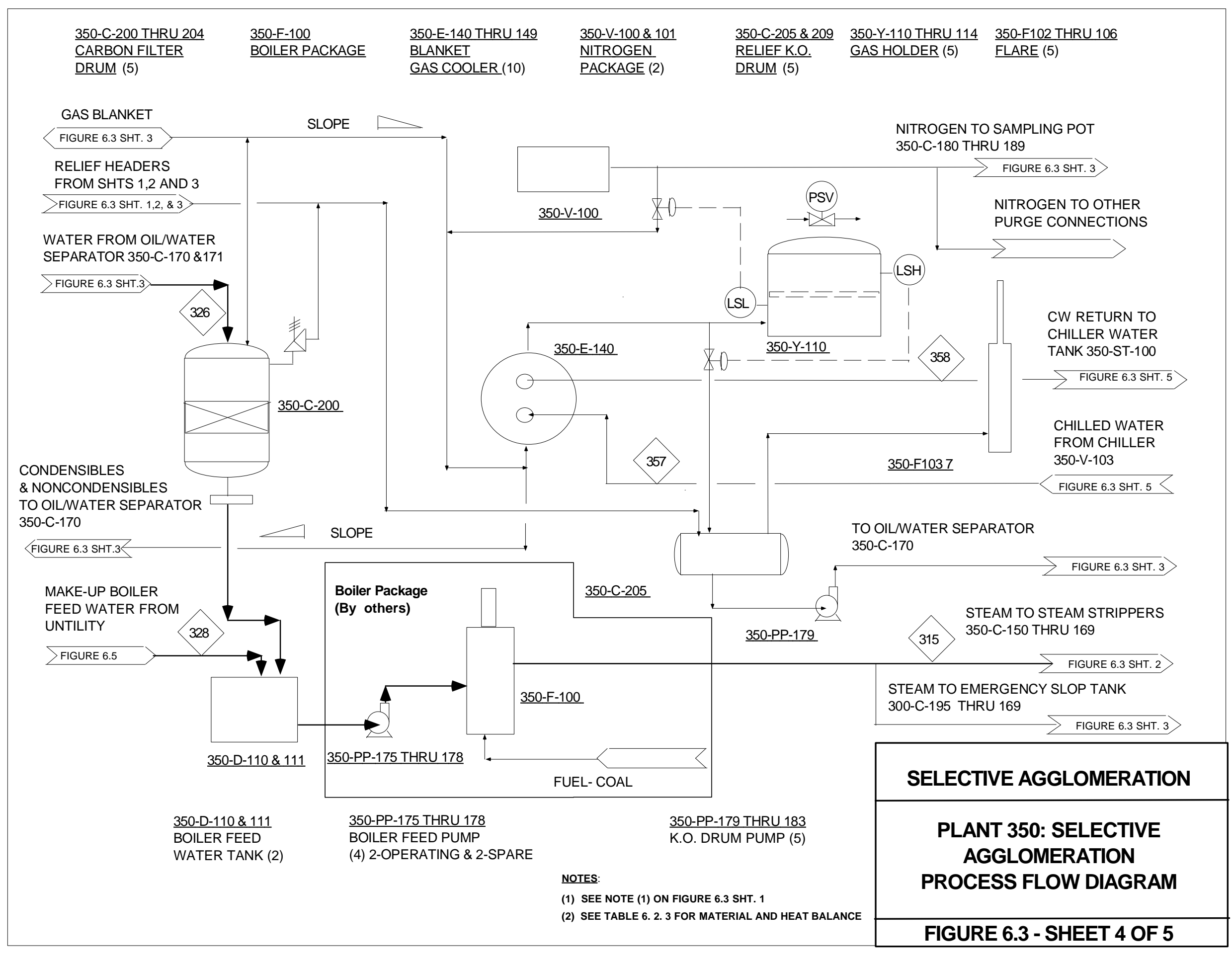




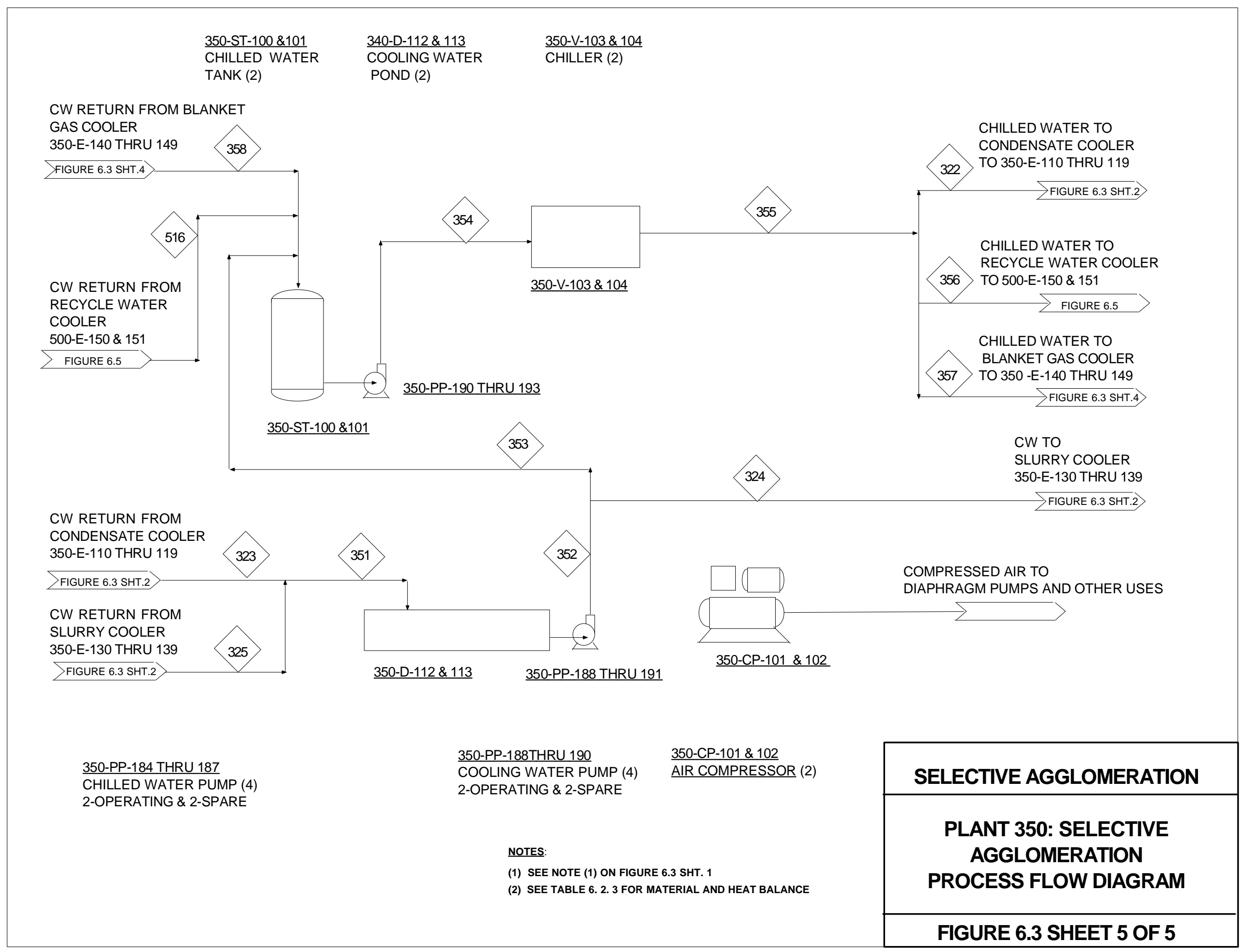




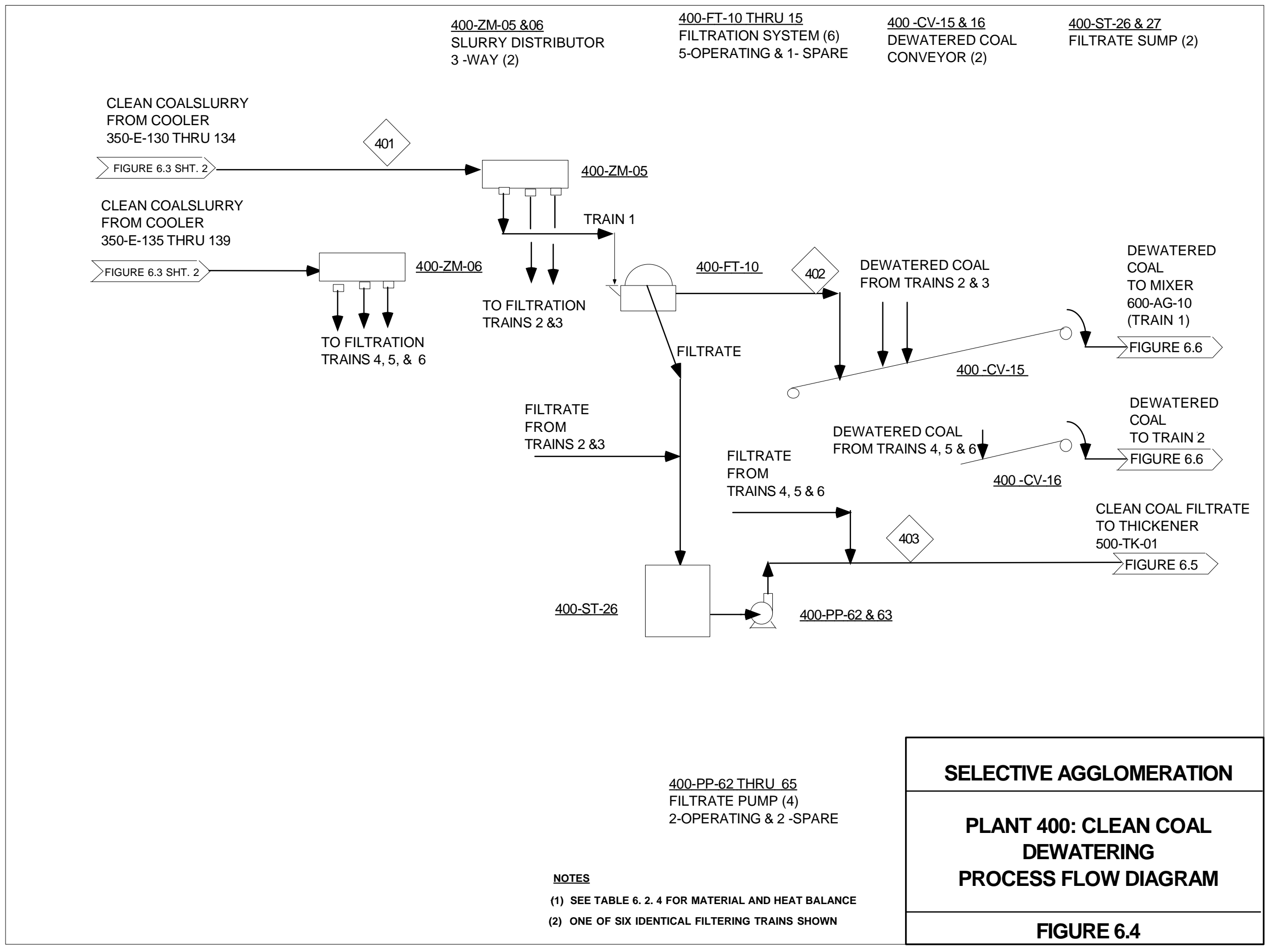




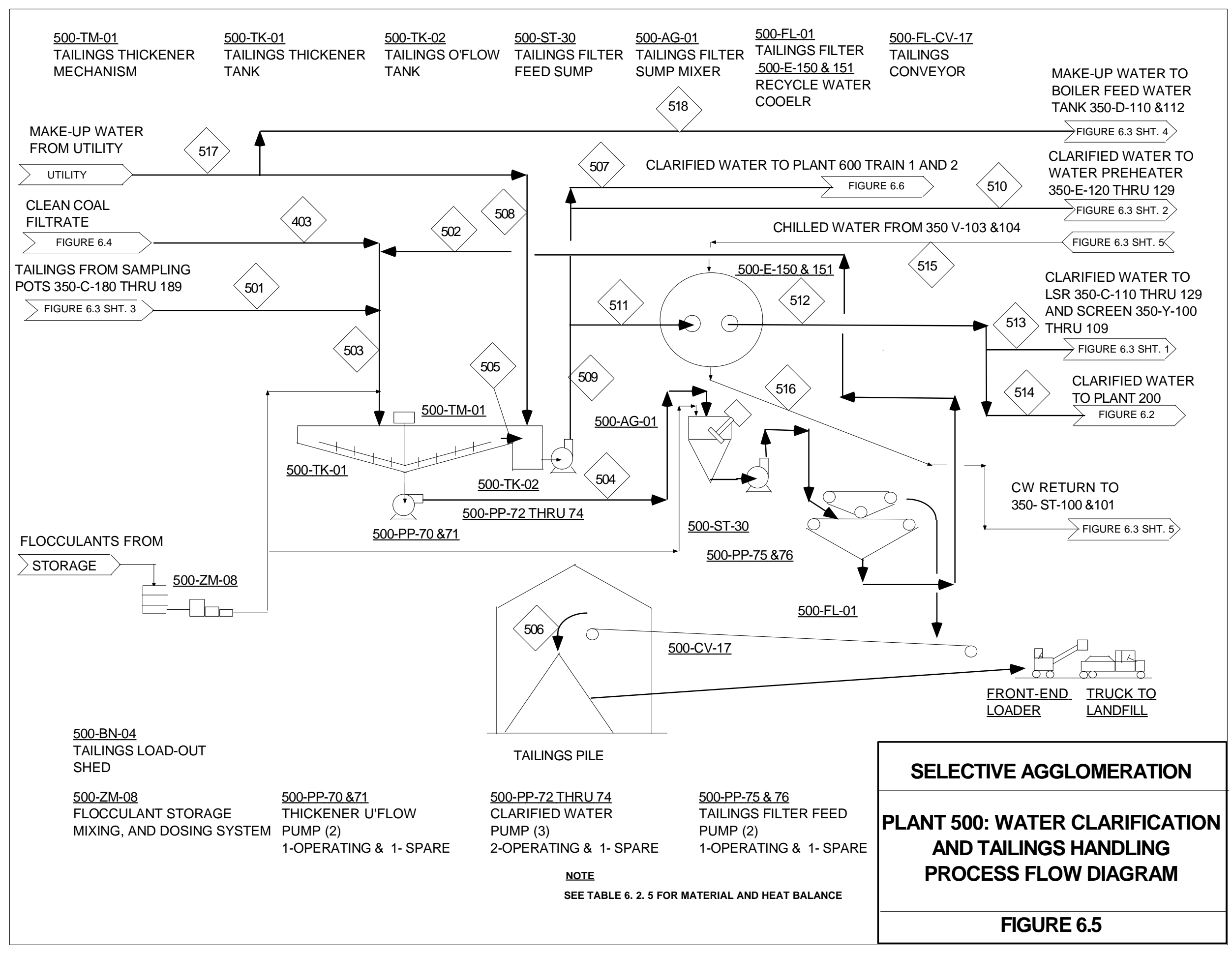




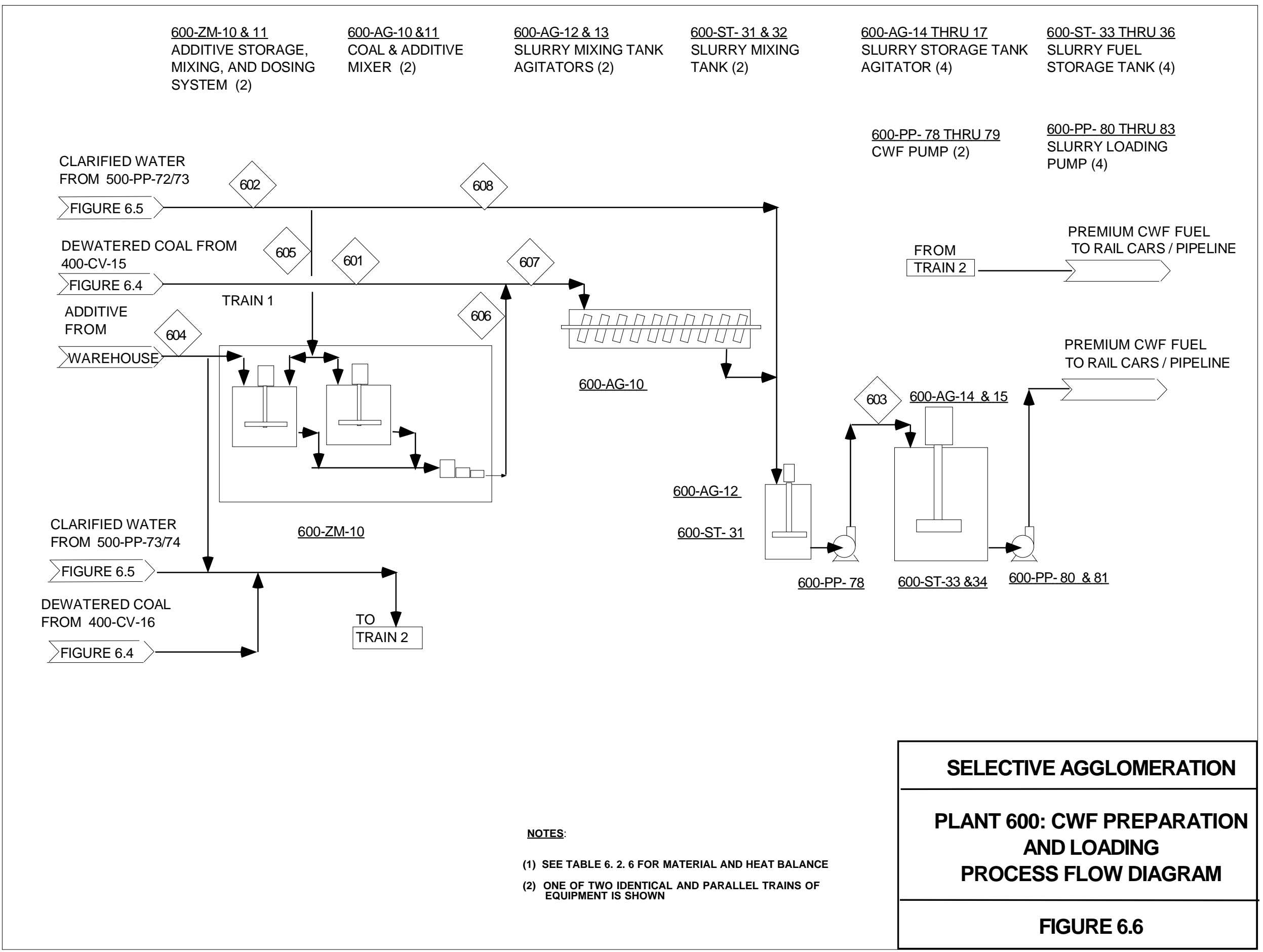




\section{Cost of Premium CWF - Column Flotation}

This section presents conceptual capital and annual operating and maintenance (O\&M) cost estimates for a commercial plant for the production of premium CWF. The plant employs the column flotation process. Based on the estimates, the cost of production of $\mathrm{CWF}(\$ / \mathrm{MBu})$ has been calculated. Further, a number of analysis have been performed to evaluate the sensitivity of the cost of production to variations in the process criteria, unit cost of selected in-puts, plant performance and capital investment.

\subsection{CAPITAL COSTS}

Capital cost estimates have been developed based on the criteria, description, flow diagrams, material balances and major equipment list included in Sections 4 and 5. Details of capital cost estimates are placed under Appendix A. A summary of the capital cost estimates is presented in Table 7.1.1 which includes a break down showing costs for different plant sections. The estimated capital cost of the project is $\$ 69.6$ million (First Quarter 1997).

\subsubsection{Total Field Costs}

Procedures employed for the development of cost estimates are consistent with the conceptual nature of the plant engineering definition at this stage. These include informal vendor contacts for pricing major equipment such as the grinding mills as well as use of current Bechtel in-house data, with extrapolation and adjustment if appropriate.

Quantities of bulk materials for civil, structural, electrical, instrumentation and piping work necessary for the construction of the plant are not computed due to lack of more detailed engineering. As per normal accepted practice in such cases, the costs of these items are estimated as percentages of identified equipment costs. The percentages are derived from Bechtel experience with similar projects.

It is expected that equipment installation and field construction work will be performed by union labor. Job hours for equipment installation have been developed using typical job hours for machinery units of similar size and nature. An average labor rate of $\$ 30$ per hour has been applied to the job hours. The rate which includes payroll additives, fringe benefits, workmen's compensation, and spot overtime has also been used for field construction job hours. It is based on current union labor agreements for a 40-hour week in the Cleveland, Ohio area.

A 3\% sales tax is included for procured items. An allowance for freight to plant site is included at 3 percent of the ex-works cost of equipment and bulks.

Indirect Field Costs which include items such as indirect manual labor, temporary construction facilities, tools and tackle, and field office are included at 60 percent of direct labor costs. 


\subsubsection{Total Project Capital Cost and Working Capital}

Total Installed Plant Cost The Total Installed Plant Cost is derived by adding engineering and home office costs as well as contingencies to the Total Field Costs.

Engineering and home office costs (engineering, procurement, and project management) are calculated at 7 percent of Total Direct Field Costs (Total Field Costs less Indirect Field Costs).

The estimated capital costs are intended to reflect costs of a 'nth' CWF production facility after problems associated with initial ventures of a new technology application have been satisfactorily resolved. Also, the column flotation section (new technology) accounts for less than 15 percent of the total field costs. Based on these consideration a provision of 15 percent has been made for contingencies.

Startup and Land An allowance of 1 percent of the Total Installed Plant Cost has been made for plant start-up and operator training. Cost of land for plant and facilities is estimated at $\$ 120,000$.

Exclusions in Capital Cost Estimates The Total Project Capital Cost does not include owners' permitting and other such costs, taxes, and escalation beyond the First Quarter of 1997. Cost of utility lines outside the plant battery limits are also not included.

Working Capital Working capital requirements have been calculated on the basis of a month's cost of coal and two month's expenditure against labor and variable O\&M costs.

\subsection{O\&M COSTS AND COST OF CWF}

The annual O\&M cost estimates are based on the design criteria shown in Section 4 and 5 conceptual information generated during the study. Calculations of annual Variable and Fixed O\&M costs are summarized in Table 7.2.1

\subsubsection{Variable O\&M Costs}

Major reagents and consumable used in the CWF production facility are: collector and frother for flotation, ball charge, flocculants, CWF additive, power and water. O\&M supplies, refuse disposal and loss of coal heating value (Btu) with tailings (refuse) are other items of Variable O\&M costs. The usage or consumption rates of these consumable are shown in Table 7.2.1. Table 7.2.2 provides details of flocculant consumption.

The O\&M cost estimates use consumption rates for the collector (fuel oil) and the frother (MIBC) at $0.75 \mathrm{lb} / \mathrm{st}$ based on the coal feed to flotation columns. This is the median value for all coals tested earlier under the program.

Consumption of balls for grinding coal is estimated at $1 \mathrm{lb} / \mathrm{st}$ of coal ground. Recommended dosage for flocculants shown in Table 8.2.2 is taken from EPRI's Coal Cleaning Cost Model (EPRI Report TRI 101025). Median values of the recommended ranges have been used in the estimates. 
Based on tests conducted in the laboratory under the program an average consumption of $10 \mathrm{lb}$ (solid) of additive A-23 has been recommended for producing the required solids loading and viscosity of the CWF.

The cost of consumable $\mathrm{O} \& \mathrm{M}$ supplies such as spare parts are estimated based on Bechtel experience at 5 percent of the cost of major equipment in the plant. Consumption rates for electric power and water have been derived from the major equipment list and material balances respectively.

An allowance of $\$ 5.00 /$ st (dry) has been made for tailings disposal. Disposal costs could vary significantly depending upon conditions at the selected site.

The plant is expected to operate with a Btu recovery of 96.1 percent. Thus tailings from the plant include 3.9 percent of the energy supplied to the CWF production plant in the form of raw coal. The monetary value of the Btu lost with the tailings is calculated based on the delivered cost of coal energy (\$/MBtu).

Based on annual consumption as described above, Variable O\&M costs have been calculated using the following unit cost rates.

\begin{tabular}{|l|l|l|}
\hline Cost Element & Unit & Cost $(\$)$ \\
\hline & & \\
Collector (fuel oil) & $\$ / \mathrm{lb}$ & 0.20 \\
Frother (MIBC) & $\$ / \mathrm{b}$ & 0.85 \\
Ball charge & $\$ /$ st & 600 \\
Flocculants & See Table & 7.2 .2 \\
CWF additive (A-23) - solids & $\$ / \mathrm{lb}$ & 0.70 \\
Electric power & $\$ / \mathrm{kWh}$ & 0.055 \\
Water & $\$ / 1000$ gal & 0.60 \\
Refuse disposal & $\$ /$ dry ton & 5.00 \\
Cost of raw coal: delivered (as received) & $\$ /$ st & 32.5 \\
& $\$ /$ MBtu & 1.24 \\
\hline
\end{tabular}

\subsubsection{Fixed O\&M Costs}

Labor costs and capital charges with interest on Working Capital are included in fixed O\&M costs.

Table 7.2.3 provides a listing of management, operating and maintenance personnel required to staff the facility. A total of 81 employees is envisaged. Labor costs are estimated at an average cost of $\$ 75,000$ per employee per annum.

Annual capital charges are calculated for the Total Project Capital cost based on a 20 year life and 15 percent rate of return which is considered reasonable. Interest on working capital has been calculated at 8 percent per annum. 


\subsubsection{Total Annual Variable and Fixed O\&M Costs- Cost of CWF}

As shown in Table 7.2.1 total Variable and Fixed O\&M costs are estimated at $\$ 0.913 / \mathrm{MBtu}$ of heating value in the premium CWF without considering the cost of coal. A break down of the costs is as follows:

\begin{tabular}{|l|c|c|}
\hline \multicolumn{1}{|c|}{ Cost Element } & \$/MBtu & $\%$ \\
\hline Capital Charges and & & \\
interest on Working & & \\
Capital & 0.27 & 29.1 \\
CWF additive, A-23 & 0.23 & 25.6 \\
Labor & 0.13 & 14.6 \\
Electric Power & 0.11 & 12.3 \\
Flotation Reagents & & \\
\& Flocculant & 0.07 & 7.5 \\
Btu Loss & 0.05 & 5.5 \\
Others & 0.05 & 5.4 \\
\hline Total Cost of CWF & 0.91 & 100.0 \\
\hline
\end{tabular}

Including the cost of coal delivered to plant site at 1.24/MBtu, the total cost of production of premium CWF is estimated at $\$ 2.15 / \mathrm{MBtu}$.

\subsection{SENSITIVITY STUDIES}

One of the major elements in the cost of production of CWF is the cost of A-23 dispersant additive. Use of the additive becomes necessary to meet the specified 60 percent solids loading of the product. If the solids loading could be reduced to around 54 percent, the product could be produced without the use of the additive A-23. In such an event the total cost of CWF would be reduced from $\$ 2.15 / \mathrm{MBtu}$ to $\$ 1.92$ representing a reduction of $\$ 0.23 / \mathrm{MBtu}$.

A series of sensitivity analysis was performed to evaluate the sensitivity of the cost of production of CWF to variations in other selected cost input parameters. The cases studied are listed in Table 7.3.1. Results of the analysis are shown in Table 7.3.2. Details of calculation are placed in Appendix C.

As may be expected, variations in coal prices have the maximum impact on the cost of CWF. The cost of coal accounts for nearly 60 percent $(57.5+2.3)$ of the cost of the product in the base case. The other significant factor is the annual production rate. 
Table 7.1.1

PREMIUM CWF PRODUCTION- COLUMN FLOTATION Capital Cost Summary

\begin{tabular}{|l|r|r|}
\hline & $\$ \times 1000$ & \multicolumn{1}{|c|}{$\%$} \\
\hline Raw Coal Handling - Plant 100 & 13,886 & 24.7 \\
Crushing and Grinding - Plant 200 & 19,249 & 34.2 \\
Column Flotation - Plant 300 & 6,984 & 12.4 \\
Clean Coal Dewatering - Plant 400 & 7,216 & 12.8 \\
Water Clarification and Tailings Handling - Plant 500 & 3,135 & 5.6 \\
CWF Preparation and Loading - Plant 600 & 5,799 & 10.3 \\
\hline Total Field Costs & 56,268 & 100.0 \\
\hline Engineering and Home Office & 3,535 & \\
Contingency @ & 8,970 \\
\hline Total Installed Plant Cost 15\% & 68,773 \\
Startup and Operator training & 688 & \\
Land-60 acres at \$ 2000 per acre & 120 \\
Total Project Capital Cost & $\mathbf{6 9 , 5 8 1}$ \\
\cline { 1 - 2 } Working Capital & $\mathbf{1 0 , 0 0 0}$ \\
\cline { 1 - 2 } & &
\end{tabular}

Not Included: Cost of permits and escalation beyond first quarter of 1997. 
Table 7.2.1

PREMIUM CWF PRODUCTION - COLUMN FLOTATION

Variable and Fixed $O \& M$ Costs - Cost of CWF

\begin{tabular}{|c|c|c|c|c|c|c|c|c|c|c|c|c|}
\hline \multirow[b]{2}{*}{ Cost element } & \multicolumn{2}{|c|}{ Usage } & \multicolumn{2}{|c|}{ Unit cost } & \multirow[b]{2}{*}{$\mathrm{st} / \mathrm{h}$} & \multirow[b]{2}{*}{$\$ / h$} & \multirow{2}{*}{$\begin{array}{c}\text { Plant } \\
\text { Availability } \\
\%\end{array}$} & \multirow[b]{2}{*}{$1000 \times \$ / y$} & \multicolumn{4}{|c|}{ Cost of CWF } \\
\hline & unit & value & unit & $\$$ & & & & & $\begin{array}{c}\$ / \text { st } \\
\text { product } \\
\text { coal }\end{array}$ & \$/MBtu & $\begin{array}{c}\% \\
\text { Excluding } \\
\text { coal }\end{array}$ & $\begin{array}{c}\% \\
\text { Including } \\
\text { coal }\end{array}$ \\
\hline \multicolumn{13}{|l|}{ Variable O\&M Costs } \\
\hline Collector & $\mathrm{lb} / \mathrm{st}$ of feed & 0.75 & $\$ / \mathrm{lb}$ & 0.20 & 233 & 35 & 81 & 249 & 0.17 & 0.006 & 0.6 & 0.3 \\
\hline Frother & $\mathrm{lb} / \mathrm{st}$ of feed & 0.75 & $\$ / l b$ & 0.85 & 233 & 149 & 81 & 1,059 & 0.71 & 0.024 & 2.6 & 1.1 \\
\hline Ball charge & $\mathrm{lb} / \mathrm{st}$ of feed & 1.00 & $\$ /$ ton & 600 & 233 & 70 & 81 & 498 & 0.33 & 0.011 & 1.2 & 0.5 \\
\hline Flocculant & (1) & & $\$ / s t$ & 11.0 & 22.6 & 248 & 81 & 1,764 & 1.18 & 0.039 & 4.3 & 1.8 \\
\hline CWF additive-A23 & $\mathrm{lb} / \mathrm{st}(2)$ & 10 & $\$ / l b$ & 0.70 & 211 & 1474 & 81 & 10,500 & 7.00 & 0.234 & 25.6 & 10.8 \\
\hline O\&M supplies (3) & & & & & & & & 773 & 0.52 & 0.017 & 1.9 & 0.8 \\
\hline Electric power (4) & $10^{\wedge} 6 \mathrm{kWh} / \mathrm{st}$ & 61 & $\$ / k W h$ & 0.055 & 211 & 705 & 81 & 5,023 & 3.35 & 0.112 & 12.2 & 5.2 \\
\hline Water & gpm & 531 & $\$ / 1000 \mathrm{gal}$ & 0.60 & & 19 & 81 & 136 & 0.09 & 0.003 & 0.3 & 0.1 \\
\hline \multicolumn{2}{|c|}{ Refuse (tailings) disposal } & & $\$ / s t$ & 5.0 & 22.6 & 113 & 81 & 806 & 0.54 & 0.018 & 2.0 & 0.8 \\
\hline Btu losses (5) & $10^{\wedge} 6 \mathrm{MBtu} / \mathrm{h}$ & 253 & $\$ / \mathrm{MBtu}$ & 1.24 & & 315 & 81 & 2,243 & 1.50 & 0.050 & 5.5 & 2.3 \\
\hline \multicolumn{2}{|c|}{ Total Variable O \& M Costs } & & & & & & & 23,052 & 15.37 & 0.514 & 56.2 & 23.8 \\
\hline Fixed O \& M Costs & & & & & & & & & & & & \\
\hline Labor & Employees & 81 & $\$ / y /$ employee & 75,000 & & & & 6,075 & 4.05 & 0.135 & 14.8 & 6.3 \\
\hline \multicolumn{4}{|c|}{ Capital Charges \& Interest on working capital (6) } & & & & & 11,916 & 7.94 & 0.265 & 29.0 & 12.3 \\
\hline \multicolumn{3}{|c|}{ Total Fixed O \& M Costs } & & & & & & 17,991 & 11.99 & 0.401 & 43.8 & 18.6 \\
\hline \multicolumn{3}{|c|}{ Total Variable and Fixed O \& M Costs } & & & & & & 41,043 & 27.36 & 0.914 & 100.0 & 42.4 \\
\hline \multicolumn{3}{|c|}{ Raw Coal } & \$/MBtu & 1.243 & & & & 55,807 & 37.2 & 1.243 & & 57.6 \\
\hline \multicolumn{8}{|c|}{ Total cost of Premium CWF including cost of raw coal } & 96,850 & 64.57 & 2.158 & & 100.0 \\
\hline
\end{tabular}

(1) Per st of dry feed to tailings (refuse) thickener and belt press filter- See Table 7.2.2

(2) Per dry st of coal

(3) $5 \%$ of major equipment cost

(4) Power consumption per st of dry coal in product

(5) Calculated Btu losses per hour $=\quad\left(233.2^{*} 14054^{*} 2000\right)-\left(211^{*} 14962 * 2000\right)=$

(6) Charges against capital cost:

'-Interest on Working Capital at

$69,581(\$ \times 1000)$, Terms- $15 \%-20 y r-$ factor $=15.98 \%$ Equals $8 \%$

253.3 MBtu/h

Equals

$11,116$ ( $\$ \times 1000$ per year $)$

800 (\$×1000 per year) 
Table 7.2.1 (continued)

PREMIUM CWF PRODUCTION - COLUMN FLOTATION Variable and Fixed $O \&$ M Costs - Cost of CWF

\section{Calculation basis}

Raw coal-HHV (dry basis)

$\mathrm{Btu} / \mathrm{lb} \quad 14,054$

Coal in product- HHV (dry basis)

Feed (dry basis)

Product (dry basis)

Btu loss $/ \mathrm{h}$

Energy recovery

Cost of raw coal (delivered)

Feed coal HV (as received)

Cost /MBtu of raw coal

14,962

$\mathrm{st} / \mathrm{h} \quad 233$

st/h 211

MBtu/h 253

$\% \quad 96.1$

$\$ /$ st

Btu/lb $\quad 13,070$

\$MBtu $\quad 1.24$

Weight recovery 
Table 7.2.2

PREMIUM CWF PRODUCTION- COLUMN FLOTATION

Flocculant Consumption

Tailings (Refuse) dry solid feed rate to thickener and belt press

$=$

$22.62 \mathrm{st} / \mathrm{h}$

\begin{tabular}{|c|c|c|c|c|c|c|c|}
\hline & \multicolumn{2}{|c|}{ Thickener } & \multicolumn{2}{|c|}{ Belt press } & \multirow{2}{*}{$\begin{array}{c}\text { Total } \\
\text { usage } \\
\text { lb/st }\end{array}$} & \multirow{2}{*}{$\begin{array}{c}\text { Reagent } \\
\text { cost (2) } \\
\$ / l b \\
\end{array}$} & \multirow{2}{*}{$\begin{array}{c}\text { Flocculant } \\
\text { cost } \\
\$ / \text { st of } \\
\text { tailings }\end{array}$} \\
\hline & $\begin{array}{c}\text { Range (1) (2) } \\
\mathrm{lb} / \mathrm{st} \\
\end{array}$ & $\begin{array}{l}\text { Value } \\
\text { used } \\
\mathrm{lb} / \mathrm{st}\end{array}$ & $\begin{array}{c}\text { Range (2) } \\
\mathrm{lb} / \mathrm{st} \\
\end{array}$ & $\begin{array}{l}\text { Value } \\
\text { used } \\
\mathrm{lb} / \mathrm{st}\end{array}$ & & & \\
\hline $\begin{array}{l}\text { Anionic } \\
\text { Cationic }\end{array}$ & $\begin{array}{l}1.5-2.5 \\
2.0-3.0\end{array}$ & $\begin{array}{l}2.0 \\
2.5\end{array}$ & $\begin{array}{l}2.5-3.5 \\
2.5-3.5\end{array}$ & $\begin{array}{l}3.0 \\
3.0\end{array}$ & $\begin{array}{l}5.0 \\
5.5\end{array}$ & $\begin{array}{l}1.75 \\
0.40\end{array}$ & $\begin{array}{l}8.8 \\
2 ?\end{array}$ \\
\hline Total cost of flocculants & & & & & & & 11.0 \\
\hline
\end{tabular}

(1) Expected range of requirement per ton of tailings fed to the thickener and belt press

(2) Source: Coal Cleaning Cost Model - EPRI, Report TRI101025, March 1993 with unit cost escalated. 
Table 7.2.3

PREMIUM CWF PRODUCTION - COLUMN FLOTATION

Operating and Maintenance Personnel

\section{Management:}

Plant Manager

General Foreman

Chemist/Engineer

Clerk

Total Management

Operating and Maintenance labor / shift:

Shift foreman

Control Room Operator

Electrician

Mechanic

Mechanic helper

Welder

Unloading and loading operations

Crushing and grinding plant

Flotation

CWF Plant

Thickener and centrifuge

Warehouse

Lab assistant

Total labor per shift

Summary

Management

Labor strength based on (4) Operating shifts $\left(^{*}\right)$

Total Employees

\begin{tabular}{l}
1 \\
1 \\
2 \\
1 \\
\hline 5 \\
\hline
\end{tabular}

\begin{tabular}{c}
1 \\
1 \\
1 \\
3 \\
3 \\
1 \\
1 \\
2 \\
1 \\
1 \\
2 \\
1 \\
1 \\
\hline 19 \\
\hline
\end{tabular}

5

76

81

$\left.{ }^{*}\right)$ Strength required to staff 3 shifts/day and 7 days/week operating schedule. 
Table 7.3.1

COST OF PREMIUM CWF - COLUMN FLOTATION

Factors for Product Cost Sensitivity Analysis

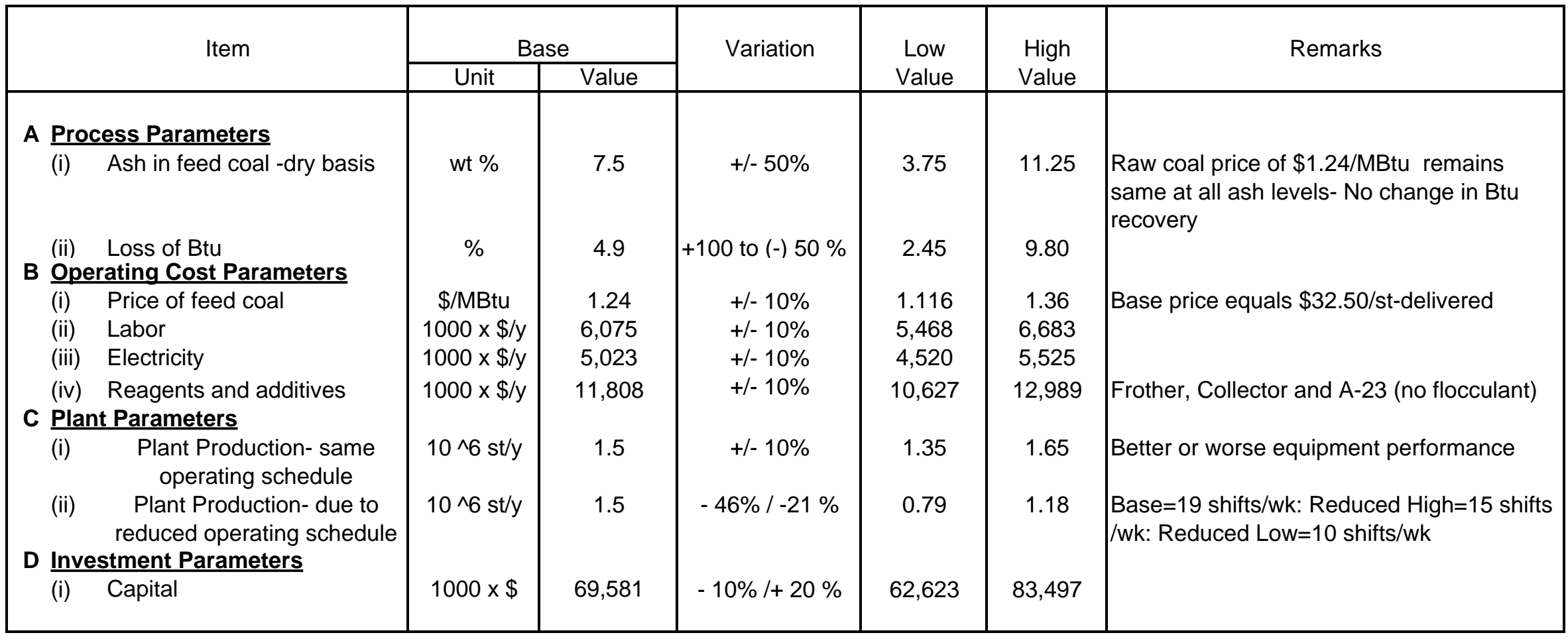


Table 7.3.2

PREMIUM CWF COST SENSITIVITY- FLOTATION

\begin{tabular}{|c|c|c|c|c|c|c|c|}
\hline & Sensitivity Study Cases & Notes & Unit & $\begin{array}{l}\text { Base } \\
\text { Value }\end{array}$ & $\begin{array}{l}\text { Low } \\
\text { Value }\end{array}$ & $\begin{array}{l}\text { High } \\
\text { Value }\end{array}$ & $\begin{array}{l}\text { Reference } \\
\text { Table in } \\
\text { Appendix C }\end{array}$ \\
\hline A & Process Parameters & & & & & & \\
\hline (i) & Ash in feed coal-dry basis & (1) & wt \% & 7.5 & 3.75 & 11.25 & \\
\hline & Cost /MBtu of Premium CWF & & $\$ /$ MBtu & 2.16 & 2.11 & 2.21 & See Table C-3 \\
\hline (ii) & Loss of Btu & (1) & $\%$ & 4.9 & 2.45 & 9.80 & \\
\hline $\mathrm{B}$ & $\begin{array}{l}\text { Cost /MBtu of Premium CWF } \\
\text { Operating Cost Parameters }\end{array}$ & & $\$ /$ MBtu & 2.16 & 2.14 & 2.17 & See Table C-3 \\
\hline (i) & Price of feed coal & & $\$ / \mathrm{MBtu}$ & 1.24 & 1.12 & 1.36 & \\
\hline & Cost /MBtu of Premium CWF & & \$/MBtu & 2.16 & 2.03 & 2.29 & See Table C-3 \\
\hline (ii) & Labor & & $1000 \times \$ / y$ & 6,075 & 5,468 & 6,683 & \\
\hline & Cost /MBtu of Premium CWF & & \$/MBtu & 2.16 & 2.14 & 2.17 & See Table C-4 \\
\hline (iii) & Electricity & & $1000 \times \$ / y$ & 5,023 & 4,520 & 5,525 & \\
\hline & Cost /MBtu of Premium CWF & & $\begin{array}{c}\$ / \mathrm{MBtu} \\
1000 \times \$ / \mathrm{v}\end{array}$ & $\begin{array}{c}2.16 \\
11.808\end{array}$ & $\begin{array}{c}2.15 \\
10627\end{array}$ & 2.17 & See Table C-4 \\
\hline (iv) & $\begin{array}{l}\text { Reagents and additives } \\
\text { Cost /MBtu of Premium CWF } \\
\text { Plant Parameters }\end{array}$ & (2) & $\begin{array}{c}1000 \times \$ / y \\
\$ / \mathrm{MBtu}\end{array}$ & $\begin{array}{l}11,808 \\
2.16\end{array}$ & $\begin{array}{c}10,627 \\
2.13\end{array}$ & $\begin{array}{c}12,989 \\
2.18\end{array}$ & $\begin{array}{l}\text { Collector, Frother \& A-23 } \\
\text { See Table C-4 }\end{array}$ \\
\hline (i) & $\begin{array}{l}\text { Plant Production- same operating schedule } \\
\text { Cost /MBtu of Premium CWF }\end{array}$ & (3) & $\begin{array}{c}10^{\wedge} 6 \mathrm{st} / \mathrm{y} \\
\$ / \mathrm{MBtu}\end{array}$ & $\begin{array}{c}1.5 \\
2.16\end{array}$ & $\begin{array}{l}1.35 \\
2.20\end{array}$ & $\begin{array}{l}1.65 \\
2.12\end{array}$ & See Table C-5 \\
\hline (ii) & Plant Production- due to reduced schedule & (4) & $10^{\wedge} 6 \mathrm{st} / \mathrm{y}$ & 1.5 & 0.79 & 1.18 & \\
\hline $\mathrm{D}$ & $\begin{array}{l}\text { Cost /MBtu of Premium CWF } \\
\text { Investment Parameters }\end{array}$ & & \$/MBtu & 2.16 & 2.40 & 2.23 & See Table C-5 \\
\hline (i) & $\begin{array}{l}\text { Capital } \\
\text { Cost /MBtu of Premium CWF }\end{array}$ & & $\begin{array}{l}1000 \times \$ \\
\$ / \mathrm{MBtu}\end{array}$ & $\begin{array}{c}69,581 \\
2.16\end{array}$ & $\begin{array}{c}62,623 \\
2.13\end{array}$ & $\begin{array}{c}83,497 \\
2.21\end{array}$ & See Table C-5 \\
\hline
\end{tabular}

(1) Raw coal price ( $\$ 1.24 / \mathrm{MBtu})$ and Btu recovery are same for these cases

(2) Flocculants not considered

(3) Better or worse equipment performance

(4) Base =19 shifts/wk: Reduced High=15 shifts /wk: Reduced Low=10 shifts/wk 


\section{Section 8}

\section{Cost of Premium CWF - Selective Agglomeration}

This section presents conceptual capital and annual operating and maintenance (O\&M) cost estimates for a commercial plant for the production of premium CWF. The plant employs the selective agglomeration process. Based on the estimates, the cost of production of CWF (\$/MBtu) has been calculated. Further, a number of analysis have been performed to evaluate the sensitivity of the cost of production to variations in the process criteria, unit cost of selected in-puts, plant performance and capital investment.

\subsection{CAPITAL COSTS}

Capital cost estimates have been developed based on the criteria, description, flow diagrams, material balances and major equipment list included in Sections 4 and 6. Details of capital cost estimates are placed under Appendix B. A summary of the capital cost estimates is presented in Table 8.1.1 which includes a break down showing costs for different plant sections. The estimated capital cost of the project is $\$ 97.24$ million (First Quarter 1997).

\subsubsection{Total Field Costs}

Procedures employed for the development cost estimates are consistent with the conceptual nature of the plant's engineering definition at this stage. These include informal vendor contacts for pricing major equipment such as the grinding mills as well as use of current Bechtel in-house data, with extrapolation and adjustment if appropriate.

Quantities of bulk materials for civil, structural, electrical, instrumentation and piping work necessary for the construction of the plant are not computed due to lack of more detailed engineering. As per normal accepted practice in such cases, the costs of these items are estimated as percentages of identified equipment costs. The percentages are derived from Bechtel experience with similar projects.

It is expected that equipment installation and field construction work will be performed by union labor. Job hours for equipment installation have been developed using typical job hours for machinery units of similar size and nature. An average labor rate of $\$ 30$ per hour has been applied to the job hours. The rate which includes payroll additives, fringe benefits, workmen's compensation, and spot overtime has also been used for field construction job hours. It is based on current union labor agreements for a 40-hour week in the Cleveland, Ohio area.

A 3\% sales tax is included for procured items. An allowance for freight to plant site is included at 3 percent of the ex-works cost of equipment and bulks.

Indirect Field Costs which include items such as indirect manual labor, temporary construction facilities, tools and tackle, and field office are included at 60 percent of direct labor costs. 


\subsubsection{Total Project Capital Cost and Working Capital}

Total Installed Plant Cost The Total Installed Plant Cost is derived by adding engineering and home office costs as well as contingencies to the Total Field Costs.

Engineering and home office costs (engineering, procurement, and project management) are calculated at 7 percent of Total Direct Field Costs (Total Field Costs less Indirect Field Costs).

The estimated capital costs are intended to reflect costs of a 'nth' CWF production facility after problems associated with initial ventures of a new technology application have been satisfactorily resolved.

The selective agglomeration section, Plant 350, accounts for approximately 38 percent of the Total Field Costs. Considering the uncertainties in the estimate for this plant section, an enhanced contingency allowance of 22.5 percent has been made for this part of the Total Field Cost. A 15 percent contingency has been allowed for the rest of the plant sections which represent relatively proven technology. Average contingency for the entire plant works out to 17.7 percent.

Startup and Land An allowance of 1 percent of the Total Installed Plant Cost has been made for plant start-up and operator training. Cost of land for plant and facilities is estimated at $\$ 120,000$.

Exclusions in Capital Cost Estimates The Total Project Capital Cost does not include owners' permitting and other such costs, taxes, and escalation beyond the First Quarter of 1997. Cost of utility lines outside the plant battery limits are also not included.

Working Capital Working capital requirements have been calculated on the basis of a month's cost of coal and two month's expenditure against labor and variable O\&M costs.

\subsection{O\&M COSTS AND COST OF CWF}

The annual O\&M cost estimates are based on the design criteria shown in Section 4 and 6 conceptual information generated during the study. Calculations of annual Variable and Fixed O\&M costs are summarized in Table 8.2.1

\subsubsection{Variable O\&M Costs}

Major reagents and consumable used in the CWF production facility are: heptane, steam, ball charge, flocculants, CWF additive (A-23), power, and water. O\&M supplies, refuse disposal and loss of coal heating value (Btu) with tailings (refuse) are other items of Variable O\&M costs. The usage or consumption rates of these consumable are shown in Table 8.2.1. Table 8.2.2 provides details of flocculant consumption.

Of the reagents used, approximately 1 percent of heptane is lost with the solids, coal and minerals, leaving the process. In addition, handling losses have been estimated at 0.05 percent of the heptane in circulation. This reflects a recovery efficiency of 98.95 percent. This level of recovery should be achievable in a continuous with completely enclosed processing vessels . 
Quantities of steam consumption are derived from heat and material balances. Consumption of ball charge for grinding coal is estimated at $1 \mathrm{lb} / \mathrm{st}$ of coal ground. Recommended dosage for flocculants shown in Table 8.2.2 is taken from EPRI's Coal Cleaning Cost Model (EPRI Report TRI 101025). Median values of the recommended ranges have been used in the estimates.

Based on tests conducted in the laboratory under the program an average consumption of $10 \mathrm{lb}$ (solid) of additive A-23 has been recommended for producing the required solids loading and viscosity of the CWF.

Consumption rates for electric power and water have been derived from the major equipment list and material balances respectively.

The cost of consumable $\mathrm{O} \& \mathrm{M}$ supplies such as spare parts are estimated based on Bechtel experience at 5 percent of the cost of major equipment in the plant.

An allowance of $\$ 5.00 /$ st (dry) has been made for tailings disposal. Disposal costs could vary significantly depending upon conditions at the selected site.

The plant is expected to operate with a Btu recovery of 99.0 percent. Thus tailings from the plant include 1.0 percent of the energy supplied to the CWF production plant in the form of raw coal. The cost of the heating value (Btu) lost with the tailings is calculated based on the delivered cost of coal energy $(\$ / \mathrm{MBtu})$.

Based on annual consumption as described above, Variable O\&M costs have been calculated using the following unit cost rates.

\begin{tabular}{|l|l|l|}
\hline Cost Element & Unit & Cost $(\$)$ \\
\hline & & \\
Heptane & $\$ / \mathrm{lb}$ & 0.175 \\
Steam & $\$ / \mathrm{MBtu}$ & 3.00 \\
Ball charge & $\$ /$ st & 600 \\
Flocculant & See Table & 8.2 .2 \\
CWF additive (A-23) - solids & $\$ / \mathrm{lb}$ & 0.70 \\
Electric power & $\$ / \mathrm{kWh}$ & 0.055 \\
Water & $\$ / 1000$ gal & 0.60 \\
Refuse disposal & $\$ /$ dry ton & 5.00 \\
Cost of raw coal: delivered & $\$ /$ st & 32.5 \\
& \$/MBtu & 1.24 \\
\hline
\end{tabular}




\subsubsection{Fixed O\&M Costs}

Labor costs and capital charges with interest on working capital are included in Fixed O\&M costs.

Table 8.2.3 provides a listing of management, operating and maintenance personnel required to staff the facility. A total of 104 employees is envisaged. Labor costs are estimated at an average cost of $\$ 75,000$ per employee per annum.

Annual capital charges are calculated for the Total Project Capital cost based on a 20 year life and 15 percent rate of return which is considered reasonable. Interest on working capital has been calculated at 8 percent per annum.

\subsubsection{Total Annual Variable and Fixed O\&M Costs- Cost of CWF}

As shown in Table 8.2.1 total Variable and Fixed O\&M costs are estimated at $\$ 1.14 / \mathrm{MBtu}$ of heating value in the premium CWF without considering the cost of coal. A break down of the costs is as follows:

\begin{tabular}{|l|c|l|}
\hline \multicolumn{1}{|c|}{ Cost Element } & \$/MBtu & $\%$ \\
\hline Capital charges and interest & & \\
on Working & 0.37 & 31 \\
Capital & 0.23 & 19 \\
CWF additive, A-23 & 0.17 & 15 \\
Labor & 0.15 & 13 \\
Electric power & 0.13 & 11 \\
Steam & 0.10 & 10 \\
Others (including Heptane) & 1.18 & 100 \\
\hline Total Cost of CWF & \\
\hline
\end{tabular}

The above data is shown graphically in Figure 1.4. Including the cost of coal (delivered to site) at $1.24 / \mathrm{MBtu}$, the total cost of production of premium CWF is estimated at $\$ 2.42 / \mathrm{MBtu}$.

The target set for the program for the cost of production of CWF is $\$ 2.50 / \mathrm{MBtu}$ including the mine mouth cost of raw coal. The above mentioned cost of $\$ 2.42 / \mathrm{MBtu}$ is based on coal cost delivered to the plant site in Ohio. It includes a transportation cost of $\$ 0.20 / \mathrm{MBtu}$ for the raw coal. Based on mine mouth coal cost, the estimated production cost is $\$ 2.22 / \mathrm{MBtu}(\$ 2.42$ less $\$ 0.20)$ which is well below the targeted cost of production. 


\section{$8.3 \quad$ SENSITIVITY STUDIES}

One of the major elements in the cost of production of CWF is the cost of A-23 dispersant additive. Use of the additive becomes necessary to meet the specified 60 percent solids loading of the product slurry. If the solids loading could be reduced to around 54 percent, the slurry could be produced without the use of the additive. In such an event the total cost of CWF would be reduced from $\$ 2.42 / \mathrm{MBtu}$ to $\$ 2.19 / \mathrm{MBtu}$ representing a reduction of $\$ 0.23 / \mathrm{MBtu}$.

A series of sensitivity analysis was performed to evaluate the sensitivity of the cost of production of CWF to variations in other selected cost input parameters. The cases considered are listed in Table 8.3.1. Results of the analysis are shown in Table 8.3.2. Details of calculation are placed in Appendix D.

As may be expected, variations in coal prices have the maximum impact on the cost of CWF. The cost of coal accounts for nearly $51.9(51.4+0.5)$ percent of the cost of the product in the base case. The other significant factor is the annual rate of production. 
Table 8.1.1

PREMIUM CWF PRODUCTION- SELECTIVE AGGLOMERATION

Capital Cost Summary

\begin{tabular}{|l|r|r|}
\hline & $\$ \times 1000$ & $\%$ \\
\hline Raw Coal Handling - Plant 100 & 13,886 & 18.1 \\
Crushing and Grinding - Plant 200 & 19,249 & 25.0 \\
Selective Agglomeration - Plant 350 & 27,868 & 36.2 \\
Clean Coal Dewatering - Plant 400 & 7,216 & 9.4 \\
Water Clarification and Tailings Handling - Plant 500 & 2,873 & 3.7 \\
CWF Preparation and Loading - Plant 600 & 5,799 & 7.5 \\
\hline Total Field Costs & 76,891 & 100.0 \\
\hline Engineering and Home Office & 4,790 & \\
Contingency-\% & 14,472 \\
\hline Total Installed Plant Cost $17.72\left(^{*}\right)$ & 96,153 \\
Startup and Operator training & 962 \\
Land-60 acres at \$ 2000 per acre & 120 \\
\hline Total Project Capital Cost & 97,235 \\
\hline Working Capital & 11,000 \\
\hline
\end{tabular}

Not Included: Cost of permits and escalation beyond first quarter of 1997.

$\left({ }^{*}\right)$ Contingency $\%=(22.5 \%$ on Selective agglomeration and $15 \%$ on rest $)$ 
Table 8.2.1

PREMIUM CWF PRODUCTION - SELECTIVE AGGLOMERATION Variable and Fixed $O$ \& M Costs - Cost of CWF

\begin{tabular}{|c|c|c|c|c|c|c|c|c|c|c|c|c|}
\hline \multirow[b]{2}{*}{ Cost element } & \multicolumn{2}{|l|}{ Usage } & \multicolumn{2}{|c|}{ Unit cost } & \multirow[b]{2}{*}{$\mathrm{st} / \mathrm{h}$} & \multirow[b]{2}{*}{$\$ / h$} & \multirow{2}{*}{$\begin{array}{c}\text { Plant } \\
\text { Availability } \\
\%\end{array}$} & \multirow[b]{2}{*}{$1000 \times \$ / y$} & \multicolumn{4}{|c|}{ Cost of CWF } \\
\hline & unit & value & unit & $\$$ & & & & & $\begin{array}{c}\$ / s t \\
\text { product } \\
\text { coal }\end{array}$ & \$/MBtu & $\begin{array}{c}\% \\
\text { Excluding } \\
\text { coal }\end{array}$ & $\begin{array}{c}\% \\
\text { Including } \\
\text { coal }\end{array}$ \\
\hline \multicolumn{2}{|c|}{ Variable 0\&M Costs } & & & & & & & & & & & \\
\hline Heptane & $\mathrm{lb} / \mathrm{st}$ of feed & 5.40 & $\$ / l b$ & 0.175 & 233 & 220 & 79 & 1,524 & 1.02 & 0.034 & 2.89 & 1.40 \\
\hline Steam & MBtu/st & 1.27 & $\$ /$ MBtu (1) & 3.0 & 217 & 825 & 79 & 5,706 & 3.80 & 0.127 & 10.81 & 5.25 \\
\hline Ball charge & $\mathrm{lb} / \mathrm{st}$ of feed & 1.00 & $\$ /$ ton & 600 & 233 & 70 & 79 & 483 & 0.32 & 0.011 & 0.92 & 0.45 \\
\hline Flocculant & & & $\$ /$ st (2) & 11.0 & 16.3 & 179 & 79 & 1,238 & 0.83 & 0.028 & 2.35 & 1.14 \\
\hline CWF additive-A23 & $\mathrm{lb} / \mathrm{st}(3)$ & 10 & $\$ / l b$ & 0.70 & 217 & 1518 & 79 & 10,500 & 7.00 & 0.234 & 19.89 & 9.67 \\
\hline O\&M supplies (4) & & & & & & & & 1,123 & 0.75 & 0.025 & 2.13 & 1.03 \\
\hline Electric power (5) & $10^{\wedge} 6 \mathrm{kWh} / \mathrm{st}$ & 82 & $\$ / k W h$ & 0.055 & 217 & 975 & 79 & 6,743 & 4.50 & 0.150 & 12.77 & 6.21 \\
\hline Water & gpm & 531 & $\$ / 1000$ gal & 0.60 & & 19 & 79 & 132 & 0.09 & 0.003 & 0.25 & 0.12 \\
\hline \multicolumn{2}{|c|}{ Refuse (tailings) disposal } & & $\$ / s t$ & 5.0 & 16.3 & 82 & 79 & 565 & 0.38 & 0.013 & 1.07 & 0.52 \\
\hline Btu losses (5) & $10^{\wedge} 6 \mathrm{MBtu} / \mathrm{h}$ & 66 & \$/MBtu & 1.24 & & 82 & 79 & 564 & 0.38 & 0.013 & 1.07 & 0.52 \\
\hline \multicolumn{2}{|c|}{ Total Variable O \& M Costs } & & & & & & & 28,579 & 19.05 & 0.637 & 54.13 & 26.32 \\
\hline \multicolumn{13}{|c|}{ Fixed O \& M Costs } \\
\hline Labor & Employees & 104 & $\$ /$ y/employee & 75,000 & & & & 7,800 & 5.20 & 0.174 & 14.77 & 7.18 \\
\hline \multicolumn{4}{|c|}{ Capital Charges \& Interest on Working Capital (6) } & & & & & 16,414 & 10.94 & 0.366 & 31.09 & 15.11 \\
\hline \multicolumn{3}{|c|}{ Total Fixed O \& M Costs } & & & & & & 24,214 & 16.14 & 0.539 & 45.87 & 22.30 \\
\hline \multicolumn{3}{|c|}{ Total Variable and Fixed 0 \& M Costs } & & & & & & 52,793 & 35.20 & 1.176 & 100.00 & 48.61 \\
\hline \multicolumn{3}{|c|}{ Raw Coal } & \$/MBtu & 1.24 & & & & 55,807 & 37.20 & 1.243 & & 51.39 \\
\hline \multicolumn{8}{|c|}{ Total cost of Premium CWF including cost of raw coal } & 108,600 & 72.40 & 2.419 & & 100.00 \\
\hline
\end{tabular}

(1) Based on \$ 6 per st of steam - EPRI Tag 1983 escalated to January 1997

(2) Per st of dry feed to tailings (refuse) thickener and belt press filter- See Table 8.2.2

15,744

(4) $5 \%$ of major equipment cost

(5) Power consumption per st of dry coal in product

(6) Calculated Btu losses per hour $=\quad\left(233.2^{*} 14054^{*} 2000\right)-\left(217^{*} 14962^{\star} 2000\right)=65.6 \mathrm{MBtu} / \mathrm{h}$

(7) Charges against capital cost of 97,235 (\$x1000) : Terms- $15 \%$-20yr-factor $\quad 15.98 \%$ Equals -Interest on working capital at 
Table 8.2.1 (continued)

PREMIUM CWF PRODUCTION - SELECTIVE AGGLOMERATION

Variable and Fixed $O \&$ M Costs - Cost of CWF

\section{Calculation basis}

Raw coal-HHV (dry basis)

Coal in product-HHV (dry basis)

Btu/lb

$\mathrm{Btu} / \mathrm{lb}$

Feed (dry basis)

Product (dry basis)

Btu loss/h

Energy recovery

Cost of raw coal (delivered)

Feed coal HHV (as received)

st/h

$\mathrm{MBtu} / \mathrm{h}$

$\%$

$\$ / s t$

$\mathrm{Btu} / \mathrm{lb}$

Cost /MBtu of raw coal (delivered)

$\$ / \mathrm{MBtu}$

Weight recovery

14,962

233

217

66
99.0

32.5

13,070

1.24

93.0 
Table 8.2.2

PREMIUM CWF PRODUCTION - SELECTIVE AGGLOMERATION

Flocculant Consumption

Tailings (Refuse) dry solid feed rate to thickener and belt press $=$

$16.35 \mathrm{st} / \mathrm{h}$

\begin{tabular}{|c|c|c|c|c|c|c|c|}
\hline & \multicolumn{2}{|c|}{ Thickener } & \multicolumn{2}{|c|}{ Belt press } & \multirow{2}{*}{$\begin{array}{l}\text { Total } \\
\text { usage } \\
\text { lb/st }\end{array}$} & \multirow{2}{*}{$\begin{array}{c}\text { Reagent } \\
\text { cost (2) } \\
\\
\$ / \mathrm{lb} \\
\end{array}$} & \multirow{2}{*}{$\begin{array}{c}\text { Flocculant } \\
\text { cost } \\
\$ / \text { st of } \\
\text { tailings } \\
\end{array}$} \\
\hline & $\begin{array}{c}\text { Range (1) (2) } \\
\text { lb/st } \\
\end{array}$ & $\begin{array}{c}\text { Value } \\
\text { used } \\
\mathrm{lb} / \mathrm{st} \\
\end{array}$ & $\begin{array}{c}\text { Range (2) } \\
\mathrm{lb} / \mathrm{st} \\
\end{array}$ & $\begin{array}{l}\text { Value } \\
\text { used } \\
\mathrm{lb} / \mathrm{st} \\
\end{array}$ & & & \\
\hline $\begin{array}{l}\text { Anionic } \\
\text { Cationic }\end{array}$ & $\begin{array}{l}1.5-2.5 \\
2.0-3.0\end{array}$ & $\begin{array}{l}2.0 \\
2.5\end{array}$ & $\begin{array}{l}2.5-3.5 \\
2.5-3.5\end{array}$ & $\begin{array}{l}3.0 \\
3.0\end{array}$ & $\begin{array}{l}5.0 \\
5.5\end{array}$ & $\begin{array}{l}1.75 \\
0.40\end{array}$ & $\begin{array}{l}8.8 \\
2.2\end{array}$ \\
\hline Total cost of flocculants & & & & & & & 11.0 \\
\hline
\end{tabular}

(1) Expected range of requirement per ton of tailings fed to the thickener and belt press

(2) Source: Coal Cleaning Cost Model - EPRI, Report TRI101025, March 1993 with unit cost escalated. 
Table 8.2.3

PREMIUM CWF PRODUCTION - SELECTIVE AGGLOMERATION Operating and Maintenance Personnel

$\begin{array}{lr}\text { Management: } & \\ \text { Plant Manager } & 1 \\ \text { General Forman } & 1 \\ \text { Chemist/Engineer } & 1 \\ \text { Clerk } & 1 \\ \text { Total Management } & 1 \\ \text { Operating and Maintenance labor / shift: } & 1 \\ \text { Shift foreman } & 1 \\ \text { Plant operator } & 3 \\ \text { Electrician } & 3 \\ \text { Mechanic } & 1 \\ \text { Mechanic helper } & 1 \\ \text { Welder } & 2 \\ \text { Unloading and loading operations } & 6 \\ \text { Crushing and grinding plant } & 2 \\ \text { Agglomeration } & 2 \\ \text { Thickener and centrifuge } & 2 \\ \text { Product handling and CWF plant } & 25 \\ \text { Lab assistant and Warehouse } & 4 \\ \text { Total labor per shift } & 100 \\ \text { Summary } & 104 \\ \text { Management } & \\ \left.\text { Labor strength based on (4) Operating shifts }{ }^{*}\right) & \\ \text { Total Employees } & \end{array}$

$\left({ }^{*}\right)$ Strength required to staff 3 shifts/day and 7 days/week operating schedule. 
Table 8.3.1

COST OF PREMIUM CWF - SELECTIVE AGGLOMERATION

Factors for Product Cost Sensitivity Analysis

\begin{tabular}{|c|c|c|c|c|c|c|}
\hline \multirow[t]{2}{*}{ Item } & \multicolumn{2}{|c|}{ Base } & \multirow[t]{2}{*}{ Variation } & \multirow{2}{*}{$\begin{array}{l}\text { Low } \\
\text { Value }\end{array}$} & \multirow{2}{*}{$\begin{array}{l}\text { High } \\
\text { Value }\end{array}$} & \multirow[t]{2}{*}{ Remarks } \\
\hline & Unit & Value & & & & \\
\hline \multicolumn{7}{|l|}{ A Process Parameters } \\
\hline (i) Ash in feed coal -dry basis & wt \% & 7.5 & $+/-50 \%$ & 3.75 & 11.25 & $\begin{array}{l}\text { Raw coal price of } \$ 1.24 / \mathrm{MBtu} \text { remains } \\
\text { same at all ash levels- No change in } \\
\text { Btu recovery }\end{array}$ \\
\hline (ii) Loss of Btu & $\%$ & 1.0 & +100 to $(-) 50 \%$ & 0.50 & 2.00 & \\
\hline \multicolumn{7}{|l|}{ B Operating Cost Parameters } \\
\hline (i) Price of feed coal & $\$ / \mathrm{MBtu}$ & 1.24 & $+/-10 \%$ & 1.116 & 1.36 & Base price equals $\$ 32.50 /$ st (delivered) \\
\hline (ii) Labor & $1000 \times \$ / y$ & 7,800 & $+/-10 \%$ & 7,020 & 8,580 & \\
\hline (iii) Electricity & $1000 \times \$ / y$ & 6,743 & $+/-10 \%$ & 6,069 & 7,418 & \\
\hline (iv) Reagents and additives & $1000 \times \$ / y$ & 12,024 & $+/-10 \%$ & 10,822 & 13,227 & \\
\hline $\begin{array}{l}\text { (v) Steam } \\
\text { C Plant Parameters }\end{array}$ & $1000 \times \$ / y$ & 5,706 & $+/-10 \%$ & 5,135 & 6,276 & \\
\hline $\begin{array}{c}\text { (i) Plant Production- same } \\
\text { operating schedule }\end{array}$ & $10^{\wedge} 6 \mathrm{st} / \mathrm{y}$ & 1.5 & $+/-10 \%$ & 1.35 & 1.65 & $\begin{array}{l}\text { Better or worse equipment } \\
\text { performance }\end{array}$ \\
\hline $\begin{array}{l}\text { (ii) Plant Production- due to } \\
\text { reduced operating } \\
\text { schedule }\left(^{*}\right) \\
\text { Investment Parameters }\end{array}$ & $10^{\wedge} 6 \mathrm{st} / \mathrm{y}$ & 1.5 & $-54 \% /-21 \%$ & 0.69 & 1.18 & $\begin{array}{l}\text { Base }=19 \text { shifts } / \text { wk } \quad \text { Reduced } \\
\text { High }=15 \text { shifts } / \text { wk } \\
\text { shifts/wk }\end{array}$ \\
\hline (i) Capital & $1000 \times \$$ & 97,235 & $-10 \% /+20 \%$ & 87,511 & 116,682 & \\
\hline
\end{tabular}

${ }^{*}$ ) When operated 10 shifts a week, or 2 shifts a day- approximately 2 hours on each working day will be lost due

orderly starts and shut downs- plant availability suffers by additional $\left(100^{\star} 2 / 16=12.5 \%\right) 12.5 \%$ compared to 3

shift operation. Selective agglomeration plant takes significantly more time than flotation systems to start and shut down. 
Table 8.3.2

PREMIUM CWF COST SENSITIVITY - SELECTIVE AGGLOMERATION

\begin{tabular}{|c|c|c|c|c|c|c|c|}
\hline & Sensitivity Study Cases & Notes & Unit & Base & $\begin{array}{l}\text { Low } \\
\text { Value }\end{array}$ & $\begin{array}{l}\text { High } \\
\text { Value }\end{array}$ & $\begin{array}{c}\text { Reference } \\
\text { Table in } \\
\text { Appendix D }\end{array}$ \\
\hline $\mathbf{A}$ & Process Parameters & & & & & & \\
\hline (i) & $\overline{\text { Ash in feed coal -dry basis }}$ & (1) & wt \% & 7.5 & 3.75 & 11.25 & \\
\hline & Cost of Premium CWF & & $\$ /$ MBtu & 2.41 & 2.36 & 2.47 & See Table D-3 \\
\hline (ii) & Loss of Btu & (1) & $\%$ & 1 & 0.5 & 1.5 & \\
\hline B & $\begin{array}{l}\text { Cost of Premium CWF } \\
\text { Operating Cost Parameters }\end{array}$ & & $\$ /$ MBtu & 2.41 & 2.40 & 2.41 & See Table D-3 \\
\hline (i) & Price of feed coal & & $\$ / \mathrm{MBtu}$ & 1.24 & 1.12 & 1.37 & \\
\hline (ii) & $\begin{array}{l}\text { Cost of Premium CWF } \\
\text { Labor }\end{array}$ & & $\begin{array}{l}\$ / \mathrm{MBtu} \\
1000 \times \$ / y\end{array}$ & $\begin{array}{l}2.41 \\
7,800\end{array}$ & $\begin{array}{l}2.28 \\
7,020\end{array}$ & $\begin{array}{l}2.53 \\
8,580\end{array}$ & See Table D-3 \\
\hline (iii) & $\begin{array}{l}\text { Cost of Premium CWF } \\
\text { Electricity }\end{array}$ & & $\begin{array}{l}\$ / \mathrm{MBtu} \\
1000 \times \$ / y\end{array}$ & $\begin{array}{l}2.41 \\
6,743\end{array}$ & $\begin{array}{l}2.39 \\
6,069\end{array}$ & $\begin{array}{l}2.43 \\
7,418\end{array}$ & See Table D-4 \\
\hline (iv) & $\begin{array}{l}\text { Cost of Premium CWF } \\
\text { Reagents and additives (Heptane \& A-23) }\end{array}$ & (2) & $\begin{array}{l}\$ / \mathrm{MBtu} \\
1000 \times \$ / y\end{array}$ & $\begin{array}{c}2.41 \\
12,024\end{array}$ & $\begin{array}{c}2.39 \\
10,822\end{array}$ & $\begin{array}{c}2.42 \\
13,227\end{array}$ & See Table D-4 \\
\hline (v) & $\begin{array}{l}\text { Cost of Premium CWF } \\
\text { Steam }\end{array}$ & & $\begin{array}{l}\$ / \mathrm{MBtu} \\
1000 \times \$ / y\end{array}$ & $\begin{array}{l}2.41 \\
5.706\end{array}$ & $\begin{array}{l}2.38 \\
5.135\end{array}$ & $\begin{array}{l}2.44 \\
6.276\end{array}$ & See Table D-4 \\
\hline C & $\begin{array}{l}\text { Cost of Premium CWF } \\
\text { Plant Parameters }\end{array}$ & & \$/MBtu & 2.41 & 2.40 & 2.42 & \\
\hline (i) & Plant Production- same operating schedule & (3) & $10^{\wedge} 6 \mathrm{st} / \mathrm{y}$ & 1.5 & 1.35 & 1.65 & \\
\hline & Cost of Premium CWF & & $\$ / M B t u$ & 2.41 & 2.47 & 2.36 & See Table D-5 \\
\hline $\begin{array}{l}\text { (ii) } \\
\text { D }\end{array}$ & $\begin{array}{l}\text { Plant Production- due to reduced schedule } \\
\text { Cost of Premium CWF } \\
\text { Investment Parameters }\end{array}$ & $(4)$ & $\begin{array}{l}10^{\wedge} 6 \mathrm{st} / \mathrm{y} \\
\$ / \mathrm{MBtu}\end{array}$ & $\begin{array}{l}1.5 \\
2.41\end{array}$ & $\begin{array}{l}0.69 \\
2.86\end{array}$ & $\begin{array}{l}1.18 \\
2.50\end{array}$ & See Table D-5 \\
\hline (i) & $\begin{array}{l}\text { Capital } \\
\text { Cost of Premium CWF }\end{array}$ & & $\begin{array}{l}1000 \times \$ \\
\$ / \mathrm{MBtu}\end{array}$ & $\begin{array}{c}97,235 \\
2.41 \\
\end{array}$ & $\begin{array}{c}87,511 \\
2.37 \\
\end{array}$ & $\begin{array}{c}106,958 \\
2.48 \\
\end{array}$ & See Table D-5 \\
\hline
\end{tabular}

(1) Raw coal price ( $\$ 1.24 / \mathrm{MBtu}$ - delivered to site) and Btu recovery are same for these cases

(2) Flocculants not considered

(3) Better or worse equipment performance

(4) Base=19 shifts/week: Reduced High=15 shifts /week: Reduced Low=10 shifts/week 


\section{Section 9}

\section{List of Acronyms and Abbreviations}

A list of Acronyms and Abbreviations used in the report is given below.

$\$$

acfm

bar

Btu

$\mathrm{ft}$

GJ

gm

gpm

$\mathrm{h}$

HV

HHV

HP

$\mathrm{k}$

$\mathrm{kg}$

$\mathrm{kJ}$

$\mathrm{kW}$

in.

$\mathrm{lb}$

$\mathrm{m}$

$\min$

$\mathrm{mm}$

MJ

$\mathrm{MJ} / \mathrm{kg}$

MBtu

O\&M

PDU

ROM

scfm

st

$\mathrm{t}$

wt

$\mathrm{y}$
U. S. Dollar

actual cubic feet per minute

one atmospheric pressure

British Thermal Unit

foot or feet

Giga $\left(10^{9}\right)$ Joules

gram

gallons per minute

hour

Heating Value

Higher Heating Value

Horse Power

kilo

kilogram

kilo $\left(10^{3}\right)$ Joules

kilowatt electricity

inch

pound

meter

minute

millimeter

Mega $\left(10^{6}\right)$ Joules

Mega Joules per kilogram

Million British thermal unit

Operating and Maintenance

Process Development Unit

Run-of-Mine

standard cubic feet per minute

short ton $(1$ short ton $=2,000 \mathrm{lb})$

metric ton (metric ton $=1,000 \mathrm{~kg}$ )

weight

year 


\section{APPENDICES}

A-1 
APPENDIX A

Capital Cost Estimate- Column Flotation

All costs are $\$ \times 1000$

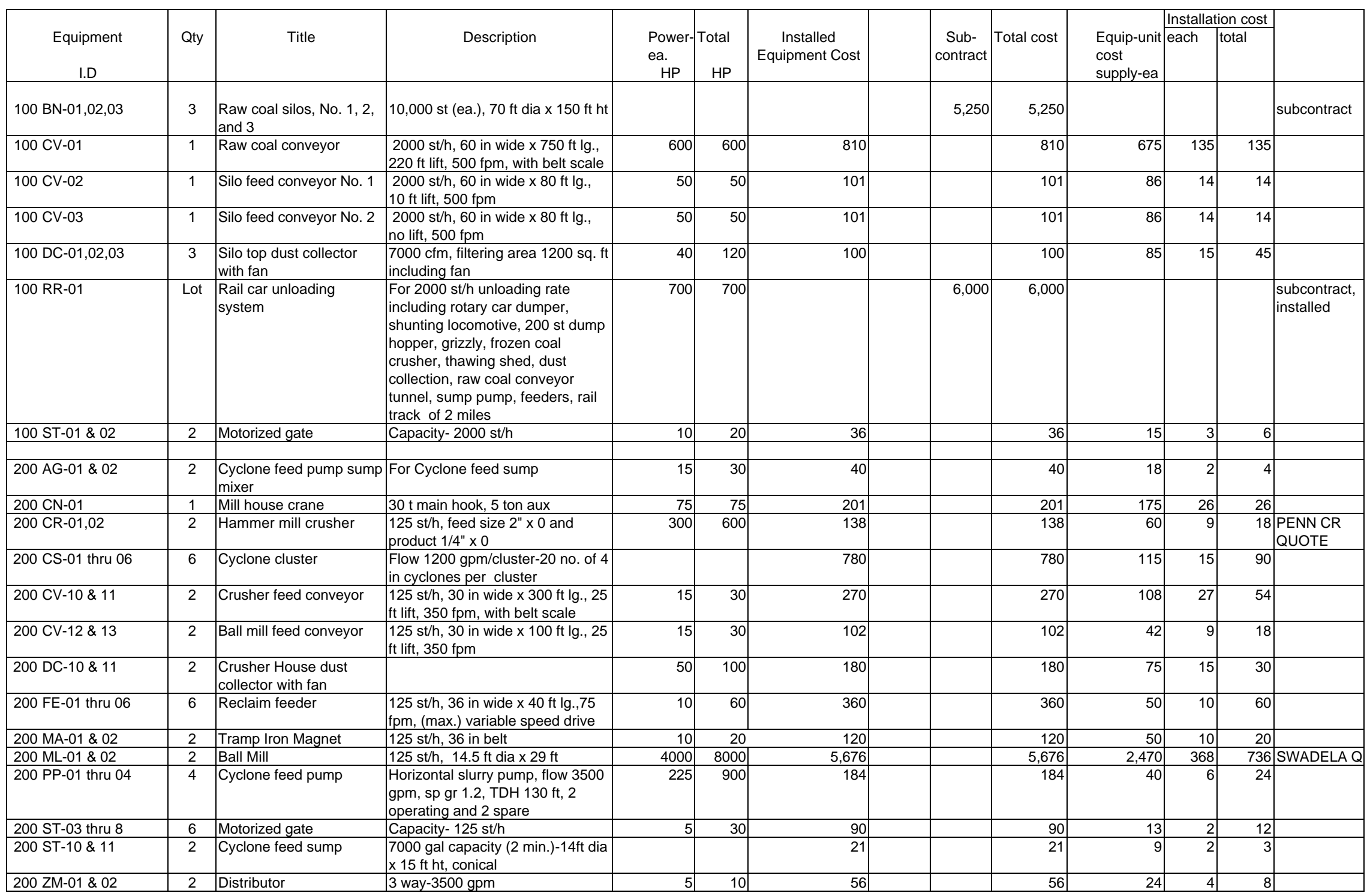


APPENDIX A

Capital Cost Estimate- Column Flotation

All costs are $\$ \times 1000$

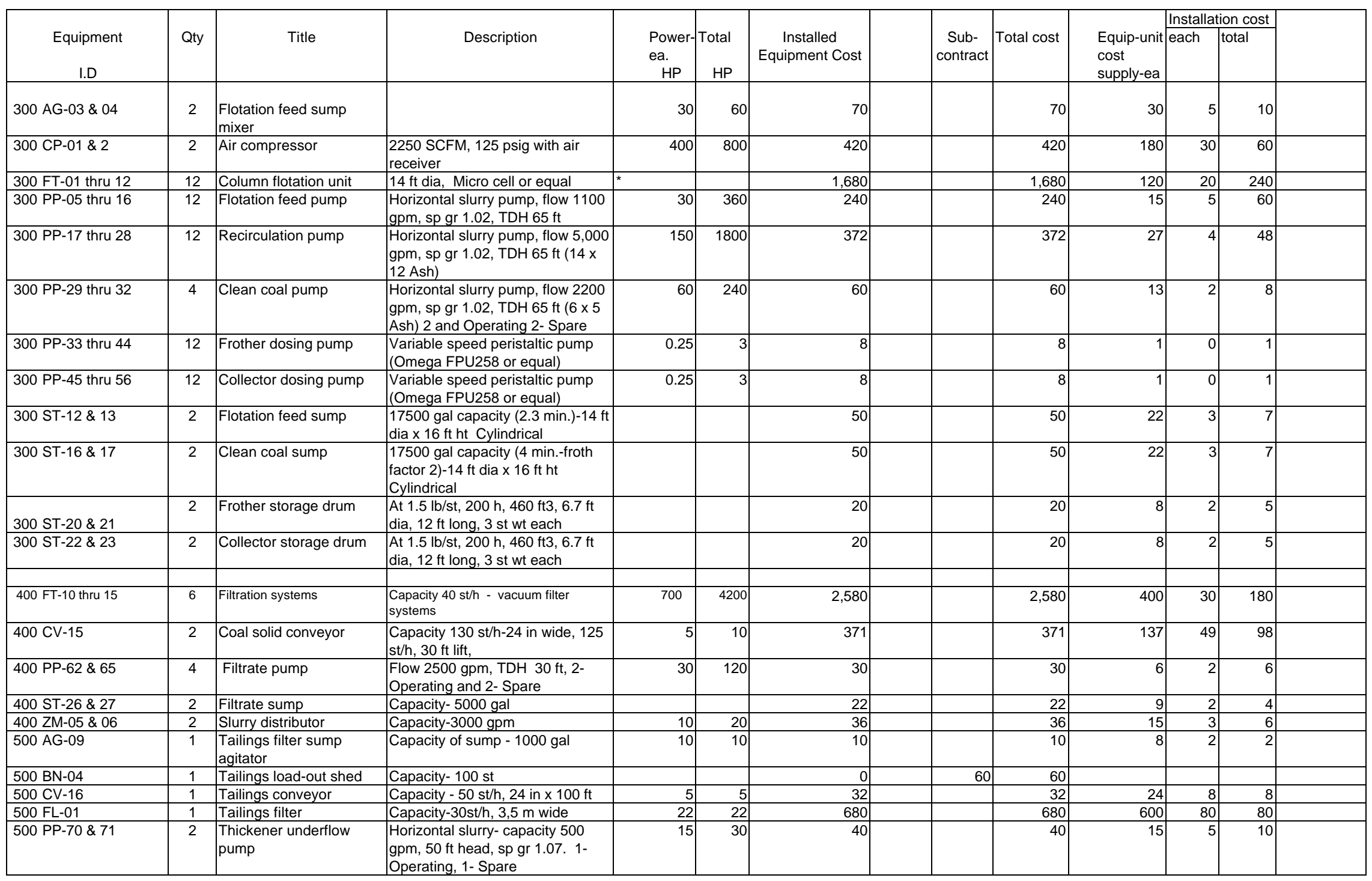


APPENDIX A

Capital Cost Estimate- Column Flotation

All costs are $\$ \times 1000$

\begin{tabular}{|c|c|c|c|c|c|c|c|c|c|c|c|c|}
\hline $\begin{array}{c}\text { Equipment } \\
\text { I.D }\end{array}$ & Qty & Title & Description & $\begin{array}{l}\text { Power- } \\
\text { ea. } \\
\text { HP }\end{array}$ & $\begin{array}{r}\text { Total } \\
\mathrm{HP} \\
\end{array}$ & $\begin{array}{c}\text { Installed } \\
\text { Equipment Cost }\end{array}$ & $\begin{array}{c}\text { Sub- } \\
\text { contract }\end{array}$ & Total cost & $\begin{array}{l}\text { Equip-unit } \\
\text { cost } \\
\text { supply-ea }\end{array}$ & \begin{tabular}{|l|} 
Installat \\
each \\
\end{tabular} & $\frac{\mid t i o n \text { cost }}{\text { total }}$ & \\
\hline 500 PP-72 thru 74 & 3 & Clarified water pump & $\begin{array}{l}\text { Horizontal water- capacity } 10,000 \\
\text { gpm, } 35 \mathrm{ft} \text { head, sp gr 1.07. 2- } \\
\text { Operating, } 1 \text { - Spare }\end{array}$ & 125 & 375 & 72 & & 72 & 20 & 4 & 12 & \\
\hline 500 PP-75 \& 76 & 2 & Tailings filter feed pump & $\begin{array}{l}\text { Capacity } 420 \mathrm{gpm}, 30 \mathrm{ft} \text { head, sp } \\
\text { gr 1.07. } 1 \text { - Operating, } 1 \text { - Spare }\end{array}$ & 15 & 30 & 40 & & 40 & 15 & 5 & 10 & \\
\hline 500 ST-30 & 1 & Tailings filter feed sump & Capacity 1000 gal & & & 11 & & 11 & 8 & 3 & 3 & \\
\hline 500 TK-01 & 1 & Tailings thickener tank & $\begin{array}{l}120 \mathrm{ft} \text { diameter thickener tank with } \\
\text { tunnel }\end{array}$ & & & & 400 & 400 & & & 0 & \\
\hline 500 TK-02 & 1 & Thickener overflow tank & Capacity 60,000 gal (concrete) & & & & 70 & 70 & & & 0 & \\
\hline 500 TM-01 & 1 & \begin{tabular}{|l|}
$\begin{array}{l}\text { Tailings thickener } \\
\text { mechanism }\end{array}$ \\
\end{tabular} & $\begin{array}{l}120 \mathrm{ft} \text { dia thickener mechanism } \\
\text { with controls }\end{array}$ & 20 & 20 & 205 & & 205 & 178 & 27 & 27 & \\
\hline $500 \mathrm{ZM}-08$ & 1 & \begin{tabular}{|l|}
$\begin{array}{l}\text { Flocculant storage,mixing } \\
\text { and dosing system }\end{array}$ \\
\end{tabular} & & 5 & 5 & 25 & & 25 & 20 & 5 & 5 & \\
\hline 600 AG-10 \& 11 & 2 & Coal additive mixer & Retention 5 min.: & 40 & 80 & 360 & & 360 & 150 & 30 & 60 & \\
\hline 600 AG-12 \& 13 & 2 & $\begin{array}{l}\text { Slurry mixing tank } \\
\text { agitator }\end{array}$ & & 40 & 80 & 82 & & 82 & 35 & 6 & 12 & \\
\hline 600 AG-14 thru 17 & 4 & $\begin{array}{l}\text { Slurry storage tank } \\
\text { agitator }\end{array}$ & & 75 & 300 & 600 & & 600 & 120 & 30 & 120 & \\
\hline 600 PP-78 \& 79 & 2 & CWF pump & \begin{tabular}{|l|} 
Horizontal slurry- Capacity-1500 \\
gpm, $60 \mathrm{ft}$ head, sp gr 1.17
\end{tabular} & 60 & 120 & 52 & & 52 & 22 & 4 & 8 & \\
\hline 600 PP-80 thru 83 & 4 & Slurry loading pump & $\begin{array}{l}\text { Horizontal slurry- Capacity-dry } \\
\text { solids } 500 \mathrm{st} / \mathrm{h} \text { - slurry } 3,000 \mathrm{gpm}, \\
60 \mathrm{ft} \text { head, sp gr } 1.17,4 \text {-Operating } \\
\text { and 4- spare }\end{array}$ & 100 & 400 & 144 & & 144 & 30 & 6 & 24 & \\
\hline 600 ST-31 \& 32 & 2 & Slurry mixing tank & 10 min. each. Volume: & & & 60 & & 60 & 25 & 5 & 10 & \\
\hline 600 ST-33 thru 36 & 4 & Slurry fuel storage tank & $\begin{array}{l}0.85 \text { million gal- } 55 \mathrm{ft} \text { dia and } 53 \mathrm{ft} \\
\text { high- total } 48 \mathrm{hr} \text {. }\end{array}$ & & & & 2500 & 2,500 & & & & \\
\hline $600 \mathrm{ZM}-10$ \& 11 & 2 & $\begin{array}{l}\begin{array}{l}\text { Flocculant storage, } \\
\text { mixing and dosing } \\
\text { system }\end{array} \\
\end{array}$ & & 10 & 20 & 140 & & 140 & 50 & 20 & 40 & \\
\hline TOTAL MAJOF & JIPME & NT & & & 20538 & 17,956 & 14280 & 32236 & & & 2,493 & \\
\hline
\end{tabular}


APPENDIX A

Capital Cost Estimate- Column Flotation

All costs are $\$ \times 1000$

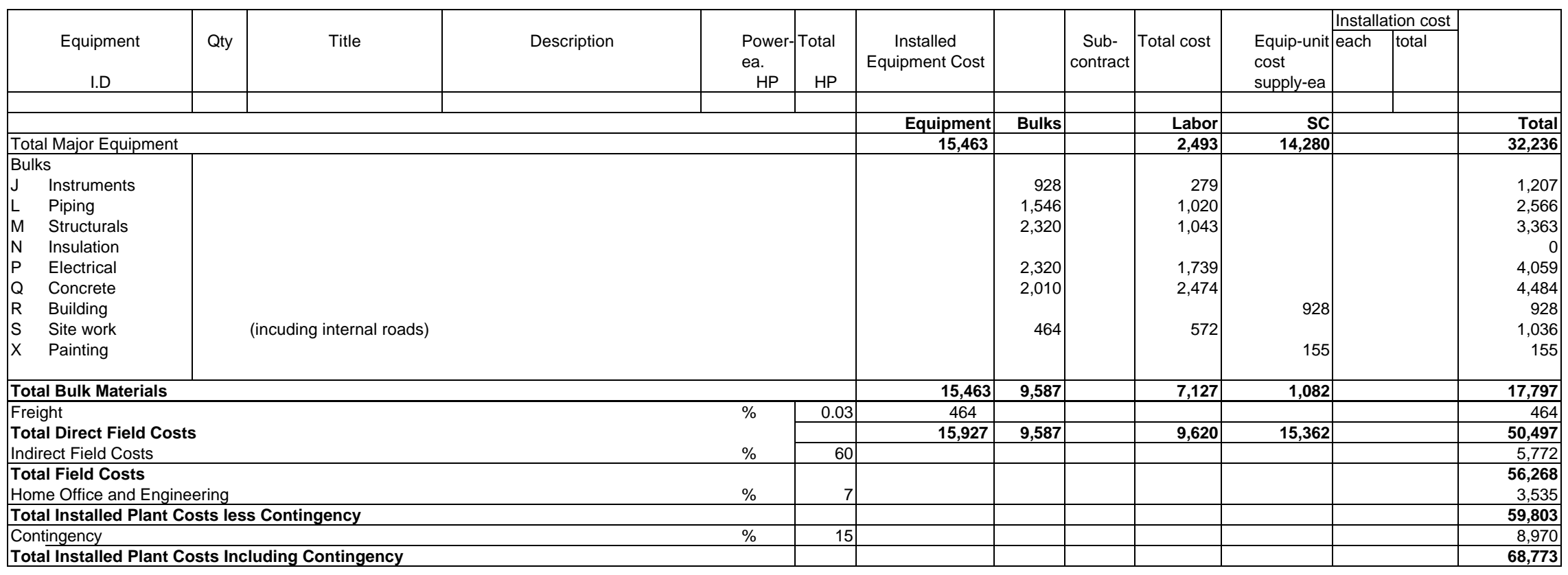

SUMMARY

Cost Breakdown

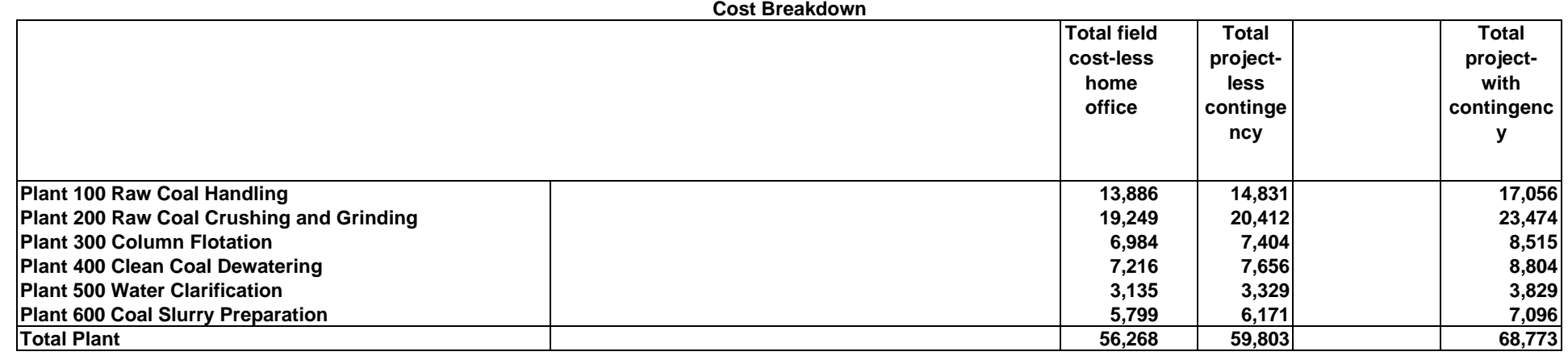




\section{APPENDIX B}

PREMIUM CWF PRODUCTION FACILITY - AGGLOMERATION

Conceptual Cost Estimate

All costs are $\$ \times 1000$

\begin{tabular}{|c|c|c|c|c|c|c|c|c|c|c|c|c|}
\hline $\begin{array}{c}\text { Equipment } \\
\text { I.D }\end{array}$ & Qty & Title & Description & $\begin{array}{r}\text { Power ea } \\
\mathrm{HP} \\
\end{array}$ & $\begin{array}{r}\text { Total } \\
\text { HP }\end{array}$ & $\begin{array}{c}\text { Installed Equipment } \\
\text { Cost }\end{array}$ & $\begin{array}{c}\text { Sub- } \\
\text { contract }\end{array}$ & Total cost & $\begin{array}{l}\text { Equip-unit } \\
\text { cost } \\
\text { supply-ea }\end{array}$ & \begin{tabular}{|l|} 
Installati \\
each \\
\end{tabular} & $\frac{t \text { tion cost }}{\text { total }}$ & \\
\hline $100 \mathrm{BN}-01,02,03$ & 3 & $\begin{array}{l}\text { Raw coal silos, No. 1, 2, } \\
\text { and } 3\end{array}$ & $10,000 \mathrm{st}$ (ea.), $70 \mathrm{ft}$ dia $\times 150 \mathrm{ft}$ ht & & & & 5,250 & 5,250 & & & & subcontract \\
\hline $100 \mathrm{CV}-01$ & 1 & Raw coal conveyor & $\begin{array}{l}2000 \mathrm{st} / \mathrm{h}, 60 \text { in wide } \times 750 \mathrm{ft} \mathrm{lg} ., \\
220 \mathrm{ft} \text { lift, } 500 \mathrm{fpm} \text {, with belt scale }\end{array}$ & 600 & 600 & 810 & & 810 & 675 & 135 & 135 & \\
\hline $100 \mathrm{CV}-02$ & 1 & Silo feed conveyor No. 1 & $\begin{array}{l}2000 \mathrm{st} / \mathrm{h}, 60 \text { in wide } \times 80 \mathrm{ft} \text { lg., } 10 \\
\mathrm{ft} \text { lift, } 500 \mathrm{fpm}\end{array}$ & 50 & 50 & 101 & & 101 & 86 & 14.4 & 14.4 & \\
\hline $100 \mathrm{CV}-03$ & 1 & Silo feed conveyor No. 2 & $\begin{array}{l}2000 \text { st/h, } 60 \text { in wide } \times 80 \mathrm{ft} \mathrm{lg.,} \\
\text { no lift, } 500 \mathrm{fpm}\end{array}$ & 50 & 50 & 101 & & 101 & 86 & 14.4 & 14.4 & \\
\hline 100 DC-01,02,03 & 3 & $\begin{array}{l}\text { Silo top dust collector with } \\
\text { fan }\end{array}$ & $\begin{array}{l}7000 \mathrm{cfm} \text {, filtering area } 1200 \mathrm{sq} . \mathrm{ft} \\
\text { including fan }\end{array}$ & 40 & 120 & 100 & & 100 & 85 & 15 & 45 & \\
\hline 100 RR-01 & Lot & Rail car unloading system & $\begin{array}{l}\text { For } 2000 \text { st/h unloading rate } \\
\text { including rotary car dumper, } \\
\text { shunting locomotive, } 200 \mathrm{st} \text { dump } \\
\text { hopper, grizzly, frozen coal } \\
\text { crusher, thawing shed, dust } \\
\text { collection, raw coal conveyor } \\
\text { tunnel, sump pump, feeders, rail } \\
\text { track of } 2 \text { miles }\end{array}$ & 700 & 700 & & 6,000 & 6,000 & & & & $\begin{array}{l}\text { subcontract, } \\
\text { installed }\end{array}$ \\
\hline 100 ST-01 \& 02 & 2 & Motorized gate & Capacity- 2000 st/h & 10 & 20 & 36 & & 36 & 15 & 3 & 6 & \\
\hline $200 \mathrm{AG}-01 \& 02$ & 2 & $\begin{array}{l}\text { Cyclone feed pump sump } \\
\text { mixers }\end{array}$ & For Cyclone feed sump & 15 & 30 & 40 & & 40 & 18 & 2 & 4 & \\
\hline $200 \mathrm{CN}-01$ & 1 & Mill house crane & $30 \mathrm{t}$ main hook, 5 ton aux & 75 & 75 & 201 & & 201 & 175 & 26.25 & 26.25 & \\
\hline $200 \mathrm{CR}-01,02$ & 2 & Hammer mill crusher & $\begin{array}{l}125 \mathrm{st} / \mathrm{h}, \text { feed size } 2 " \text { × } 0 \text { and } \\
\text { product } 1 / 4 " \text { × } 0\end{array}$ & 300 & 600 & 138 & & 138 & 60 & 9 & 18 & \\
\hline 200 CS-01 thru 06 & 6 & Cyclone cluster & $\begin{array}{l}\text { Flow } 1200 \mathrm{gpm} / \text { cluster-20 no. of } 4 \\
\text { in cyclones per cluster }\end{array}$ & & & 780 & & 780 & 115 & 15 & 90 & \\
\hline $200 \mathrm{CV}-10 \& 11$ & 2 & Crusher feed conveyor & $\begin{array}{l}125 \mathrm{st} / \mathrm{h}, 30 \mathrm{in} \text { wide } \times 300 \mathrm{ft} \lg ., 25 \\
\mathrm{ft} \mathrm{lift,} 350 \mathrm{fpm} \text {, with belt scale }\end{array}$ & 15 & 30 & 270 & & 270 & 108 & 27 & 54 & \\
\hline $200 \mathrm{CV}-12 \& 13$ & 2 & Ball mill feed conveyor & $\begin{array}{l}125 \mathrm{st} / \mathrm{h}, 30 \mathrm{in} \text { wide } \times 100 \mathrm{ft} \lg ., 25 \\
\mathrm{ft} \text { lift, } 350 \mathrm{fpm}\end{array}$ & 15 & 30 & 102 & & 102 & 42 & 9 & 18 & \\
\hline 200 DC-10 \& 11 & 2 & $\begin{array}{l}\begin{array}{l}\text { Crusher House dust } \\
\text { collector with fan }\end{array} \\
\end{array}$ & & 50 & 100 & 180 & & 180 & 75 & 15 & 30 & \\
\hline $200 \mathrm{FE}-01$ thru 06 & 6 & Reclaim feeders & $\begin{array}{l}125 \mathrm{st} / \mathrm{h}, 36 \text { in wide } \times 40 \mathrm{ft} \text { lg.,75 } \\
\mathrm{fpm} \text {, (max.) variable speed drive }\end{array}$ & 10 & 60 & 360 & & 360 & 50 & 10 & 60 & \\
\hline & 2 & Tramp Iron Magnet & $125 \mathrm{st} / \mathrm{h}, 36$ in belt & 10 & 20 & 120 & & 120 & 50 & 10 & 20 & \\
\hline $200 \mathrm{ML}-01 \& 02$ & 2 & Ball Mill & $125 \mathrm{st} / \mathrm{h}, 14.5 \mathrm{ft}$ dia $\times 29 \mathrm{ft}$ & 4000 & 8000 & 5,676 & & 5,676 & 2,470 & 368 & 736 & SWADELA \\
\hline 200 PP-01 thru 04 & 4 & Cyclone feed pump & $\begin{array}{l}\text { Horizontal slurry pump, flow } 3500 \\
\text { gpm, sp gr } 1.2, \mathrm{TDH} 130 \mathrm{ft}, 2 \\
\text { operating and } 2 \text { spare }\end{array}$ & 225 & 900 & 184 & & 184 & 40 & 6 & 24 & \\
\hline & & & & & 0 & & & & & & 0 & \\
\hline 200 ST-03 thru 8 & 6 & Motorized gate & Capacity- 125 st $/ \mathrm{h}$ & 5 & 30 & 90 & & 90 & 13 & 2 & 12 & \\
\hline 200 ST-10 \& 11 & 2 & Cyclone feed sump, & $\begin{array}{l}7000 \mathrm{gal} \text { capacity (2 min.)-14ft dia } \\
\times 15 \mathrm{ft} \mathrm{ht} \text {, conical }\end{array}$ & & & 21 & & 21 & 9 & 1.5 & 3 & \\
\hline
\end{tabular}




\section{APPENDIX B}

PREMIUM CWF PRODUCTION FACILITY - AGGLOMERATION

Conceptual Cost Estimate All costs are $\$ \times 1000$

\begin{tabular}{|c|c|c|c|c|c|c|c|c|c|c|c|c|}
\hline $\begin{array}{c}\text { Equipment } \\
\text { I.D }\end{array}$ & Qty & Title & Description & $\begin{array}{c}\text { Power ea } \\
\text { HP } \\
\end{array}$ & $\begin{array}{r}\text { Total } \\
\text { HP } \\
\end{array}$ & $\begin{array}{c}\text { Installed Equipment } \\
\text { Cost }\end{array}$ & $\begin{array}{c}\text { Sub- } \\
\text { contract }\end{array}$ & Total cost & $\begin{array}{l}\text { Equip-unit } \\
\text { cost } \\
\text { supply-ea }\end{array}$ & \begin{tabular}{|l|} 
Installat \\
each \\
\end{tabular} & $\frac{\mid \text { tion cost }}{\text { total }}$ & \\
\hline 200 ZM-01 \& 02 & 2 & Distributor & 3 way- $3500 \mathrm{gpm}$ & 5 & 10 & 56 & & 56 & 24 & 4 & 8 & \\
\hline 350 AG-90 thru 99 & 10 & Feed tank agitator & Tank volume -4000 gals. & 1.5 & 15 & 55 & & 55 & 5 & 0.5 & 5 & \\
\hline 350 AG-100 thru 109 & 10 & HSR impeller & & 400 & 4000 & 1,815 & & 1,815 & 166 & 15 & 150 & \\
\hline 350 AG-109 thru 129 & 20 & LSR impeller & & 50 & 1000 & 760 & & 760 & 33 & 5 & 100 & \\
\hline 350 AG-130 thru 139 & 10 & Froth skimmer & & 5 & 50 & 251 & & 251 & 21 & 4 & 40 & \\
\hline 350 AG-140 thru 149 & 10 & Steam stripper feed mixer & deleted & & & & & & & & & \\
\hline 350 AG-150 thru 159 & 10 & Steam stripper A agitator & & 20 & 200 & 400 & & 400 & 36 & 4 & 40 & \\
\hline 350 C-100 thru 109 & 10 & HSR vessel & $\begin{array}{l}\text { Volume: } 360 \text { gals. Diameter: } 38 \\
\text { inch ht } 88 \text { inch - CS- Design } \\
\text { Pressure } 15 \text { psig- Temp } 145 \text { deg } \\
\text { F. } 34 \text { secs. }\end{array}$ & 0 & 0 & 160 & & 160 & 13 & 3.5 & 35 & \\
\hline 350 C-110 thru 129 & 20 & LSR vessel & $\begin{array}{l}\text { Volume } 1445 \text { gals. Diameter: } 60 \\
\text { inch ht } 132 \text { inch - CS- Design } \\
\text { Pressure } 15 \text { psig- Temp } 145 \text { deg } \\
\text { F. } 184 \text { secs. }\end{array}$ & $\overline{0}$ & 0 & 437 & & 437 & 15 & 7 & 140 & \\
\hline 350 C-130 thru 139 & 10 & Froth skimmer tank & Volume: 2000 gals. $-2.5 \mathrm{~min}$ & & 0 & 184 & & 184 & 16 & 2 & 20 & \\
\hline 350 C-140 thru 149 & 10 & Steam stripper feed drum & Volume: 300 gals.- $1 \mathrm{~min}$ & & 0 & 94 & & 94 & 7 & 2 & 20 & \\
\hline 350 C-150 thru 159 & 10 & Steam stripper A & Volume: 1500 gals. $-5 \mathrm{~min}$ & & 0 & 267 & & 267 & 23 & 4 & 40 & \\
\hline 350 C-160 thru 169 & 10 & Steam stripper B & Volume: 3000 gals.- $10 \mathrm{~min}$ & & 0 & 448 & & 448 & 39 & 6 & 60 & \\
\hline $350 \mathrm{C}-170$ thru 179 & 10 & Oil/water separator & Volume: 750 gals. $-15 \mathrm{~min}$ & & 0 & 115 & & 115 & 9 & 2 & 20 & \\
\hline 350 C-180 thru 189 & 10 & Sampling pot & Volume: 200 gals. - 15 secs & & 0 & 60 & & 60 & 5 & 1 & 10 & \\
\hline 350 C-190 thru 194 & 10 & Heptane drum & Volume: 700 gals. $-20 \mathrm{~min}$ & & 0 & 98 & & 98 & 8 & 2 & 20 & \\
\hline 350 C-195 thru 199 & 5 & Emergency slop tank & 5000 gals & & 0 & 119 & & 119 & 20 & 3.5 & 17.5 & \\
\hline $350 \mathrm{C}-200$ thru 204 & 5 & Carbon filter drum & 600 gals & & 0 & 325 & & 325 & 60 & 5 & 25 & \\
\hline 350 C-204 thru 209 & 5 & Relief KO drum & 800 gals & & 0 & 59 & & 59 & 10 & 2 & 10 & \\
\hline $350 \mathrm{CP}-01$ & 1 & Air compressor & $\begin{array}{l}1000, \text { SCFM, } 125 \text { psig with air } \\
\text { receiver }\end{array}$ & 150 & 150 & 158 & & 158 & 150 & 8.00 & 8 & \\
\hline 350 D-100 thru 109 & 10 & Floor sump & 5000 gals. Concrete & & 0 & 0 & 8 & 8 & & & & \\
\hline 350 D-110 \& 111 & 2 & Boiler feed water tank & 5000 gals. Concrete & & 0 & 0 & 120 & 120 & & & & \\
\hline 350 D-112 \& 113 & 2 & Cooling water pond & 400,000 gals & & 0 & 0 & 200 & 200 & & & & \\
\hline & & & & & 0 & 0 & & 0 & & & & \\
\hline 350 E-100 thru 109 & 10 & Vapor condenser & Air Cooler-Heat Duty: $11 \mathrm{MMBtu} / \mathrm{h}$ & 60 & 600 & 692 & & 692 & 67 & 2.0 & 20 & \\
\hline $350 \mathrm{E}-110$ thru 119 & 10 & Condensate cooler & Plate type-Heat Duty: $1 \mathrm{MMBtu} / \mathrm{h}$ & & 0 & 68 & & 68 & 5 & 2.0 & 20 & \\
\hline $350 \mathrm{E}-120$ thru 129 & 10 & Water preheater & Plate type-Heat Duty: $7 \mathrm{MMBtu} / \mathrm{h}$ & & 0 & 176 & & 176 & 16 & 2.0 & 20 & \\
\hline 350 E-130 thru 139 & 10 & Slurry cooler & Plate type-Heat Duty: $12 \mathrm{MMBtu} / \mathrm{h}$ & & 0 & 565 & & 565 & 51 & 5.0 & 50 & \\
\hline 350 E-140 thru 149 & 10 & Blanket gas cooler & $\begin{array}{l}\text { Plate type-Heat Duty: } 150,000 \\
\text { Btu/h }\end{array}$ & & 0 & 92 & & 92 & 7 & 2.0 & 20 & \\
\hline $350 \mathrm{~F}-100$ & 1 & Steam lines & 然 & $\underline{0}$ & 0 & & 196 & 196 & & & & \\
\hline 350 F-102 \& 106 & 5 & Flare & & 0 & 0 & 364 & & 364 & 64 & 9.0 & 45 & \\
\hline
\end{tabular}




\section{APPENDIX B}

PREMIUM CWF PRODUCTION FACILITY - AGGLOMERATION

Conceptual Cost Estimate

All costs are $\$ \times 1000$

\begin{tabular}{|c|c|c|c|c|c|c|c|c|c|c|c|c|c|}
\hline $\begin{array}{l}\text { Equipment } \\
\text { I.D }\end{array}$ & Qty & Title & Description & $\begin{array}{r}\text { Power ea } \\
\text { HP } \\
\end{array}$ & $\begin{array}{r}\text { Total } \\
\mathrm{HP} \\
\end{array}$ & $\begin{array}{c}\text { Installed Equipment } \\
\text { Cost }\end{array}$ & $\begin{array}{c}\text { Sub- } \\
\text { contract }\end{array}$ & Total cost & $\begin{array}{l}\text { Equip-unit } \\
\text { cost } \\
\text { supply-ea }\end{array}$ & \begin{tabular}{|l|l|l|}
\multicolumn{2}{|l|}{ Installatic } \\
each & $\mathrm{t}$ \\
\end{tabular} & $\begin{array}{l}\text { ion cost } \\
\text { total }\end{array}$ & & \\
\hline 350 PP-100 thru 109 & 10 & HSR feed pump & $\begin{array}{l}\text { Horizontal slurry pump, flow } 800 \\
\text { gpm, sp gr 1.02, TDH } 80 \mathrm{ft}\end{array}$ & 30 & 300 & 200 & & 200 & 15 & 5.0 & 50 & & \\
\hline 350 PP-110 thru 119 & 10 & Tailings transfer pump & $\begin{array}{l}\text { Horizontal slurry pump, flow } 1000 \\
\text { gpm, sp gr } 1.01, \mathrm{TDH} 50 \mathrm{ft}\end{array}$ & 25 & 250 & 30 & & 30 & 3 & & 0 & & \\
\hline 350 PP-120 thru 129 & 10 & Sump pump & $\begin{array}{l}\text { Vertical slurry pump, flow } 50 \mathrm{gpm} \text {, } \\
\text { sp gr } 1.2, \mathrm{TDH} 50 \mathrm{ft}\end{array}$ & 5 & 50 & 100 & & 100 & 8 & 2.0 & 20 & & \\
\hline 350 PP-130 thru 139 & 10 & $\begin{array}{l}\text { Steam stripper A feed } \\
\text { pump }\end{array}$ & $\begin{array}{l}\text { Diaphragm type, flow } 350 \text { gpm, sp } \\
\text { gr 1.05, Delta P } 20 \text { psi, Design } \\
\text { temp 240 deg F }\end{array}$ & & 0 & 230 & & 230 & 20 & 3.0 & 30 & & \\
\hline 350 PP-140 thru 149 & 10 & $\begin{array}{l}\text { Steam stripper B feed } \\
\text { pump }\end{array}$ & \begin{tabular}{|l|} 
Progressive cavity pump, flow 350 \\
gpm, sp gr 1.05 , Design Pressure \\
50 psi, Delta P 30 psi, Design temp \\
250 deg F
\end{tabular} & 10 & 100 & 350 & & 350 & 30 & 5.0 & 50 & & \\
\hline 350 PP-150 thru 159 & 10 & Clean coal slurry pump & \begin{tabular}{|l|} 
Progressive cavity pump, flow 350 \\
gpm, sp gr 1.05 , Design Pressure \\
50 psi, Delta P 30 psi, Design temp \\
250 deg F
\end{tabular} & 10 & 100 & 350 & & 350 & 30 & 5.0 & 50 & & \\
\hline 350 PP-160 thru 169 & 10 & Heptane pump & \begin{tabular}{|l} 
Metering type, flow $400 \mathrm{gpm}, \mathrm{sp}$ gr \\
0.7, Design Pressure $30 \mathrm{psi}$, Delta \\
P 30 psi, Design temp 100 deg F
\end{tabular} & 10 & 100 & 310 & & 310 & 25 & 6.0 & 60 & & \\
\hline 350 PP-170 thru 174 & 5 & Emergency slop pump & $\begin{array}{l}\text { Diaphragm type, flow } 350 \mathrm{gpm}, \mathrm{sp} \\
\text { gr 1.05, Delta P } 20 \text { psi, Design } \\
\text { temp 220 deg F }\end{array}$ & 10 & 50 & 340 & & 340 & 60 & 8.0 & 40 & & \\
\hline 350 PP-175 thru 178 & 4 & Not used & & & & & & & & & & & \\
\hline 350 PP-179 thru 183 & 5 & K. O. Drum pump & & 3 & 15 & 30 & & 30 & 5 & 1.0 & 5 & & \\
\hline 350 PP-184 thru 187 & 4 & Chilled water pump & $\begin{array}{l}\text { Horizontal water pump, flow } 1700 \\
\text { gpm, TDH } 120 \mathrm{ft}, 2 \text { Operating and } \\
2 \text { spare }\end{array}$ & $\overline{3}$ & 12 & 30 & & 30 & 6 & 1.5 & 6 & & \\
\hline 350 PP-188 thru 191 & 4 & Cooling water pump & $\begin{array}{l}\text { Horizontal water pump, flow } 3000 \\
\text { gpm, TDH } 120 \mathrm{ft}, 2 \text { Operating and } \\
2 \text { spare }\end{array}$ & 150 & 600 & 40 & & 40 & 8 & 2.0 & 8 & & \\
\hline 350 ST-90 thru 99 & 10 & Agglomeration feed tank & capacity- 4000 gal $(6 \mathrm{~min})$ & & 0 & 70 & & 70 & 6 & 1.0 & 10 & & \\
\hline 350 ST- $100 \& 101$ & 2 & Chilled water tank & $\begin{array}{l}17500 \text { gal capacity }-14 \mathrm{ft} \text { dia } \times 16 \mathrm{ft} \\
\text { ht Cylindrical- } 10 \text { min total }\end{array}$ & $\overline{0}$ & 0 & 34 & & 34 & 15 & 2.0 & 4 & & \\
\hline $350 \mathrm{~V}-101 \& 102$ & 2 & Nitrogen package & & & 0 & 0 & 300 & 300 & 0 & 0.0 & 0 & & \\
\hline $350 \mathrm{~V}-103 \& 104$ & 2 & Chiller & duty $=8.5 \mathrm{MBtu} / \mathrm{h}$ & 800 & 1600 & 346 & & 346 & 153 & 20.0 & 40 & & \\
\hline & & & & & 0 & 0 & & 0 & & & 0 & & \\
\hline $350 \mathrm{Y}-100$ thru 109 & 10 & Screen & $6^{\prime} \times 16^{\prime}$ feet & 15 & 150 & 730 & & 730 & 65 & 8.0 & 80 & & \\
\hline 350 Y-110 thru 114 & 5 & Gas holder and blanketing & & & 0 & 0 & 250 & 250 & & & 0 & & \\
\hline 350 ZM-100 \& 101 & 2 & 5-way distributor & Flow- $3500 \mathrm{gpm}$ & & 0 & 22 & & 22 & 9 & 2.0 & 4 & & \\
\hline 400 FT-10 thru 15 & 6 & Filtration systems & $\begin{array}{l}\text { Capacity } 40 \mathrm{st} / \mathrm{h} \text { - vacuum filter } \\
\text { systems }\end{array}$ & 700 & 4200 & 2,580 & & 2,580 & 400 & 30 & 180 & & \\
\hline
\end{tabular}




\section{APPENDIX B}

PREMIUM CWF PRODUCTION FACILITY - AGGLOMERATION

Conceptual Cost Estimate

All costs are $\$ \times 1000$

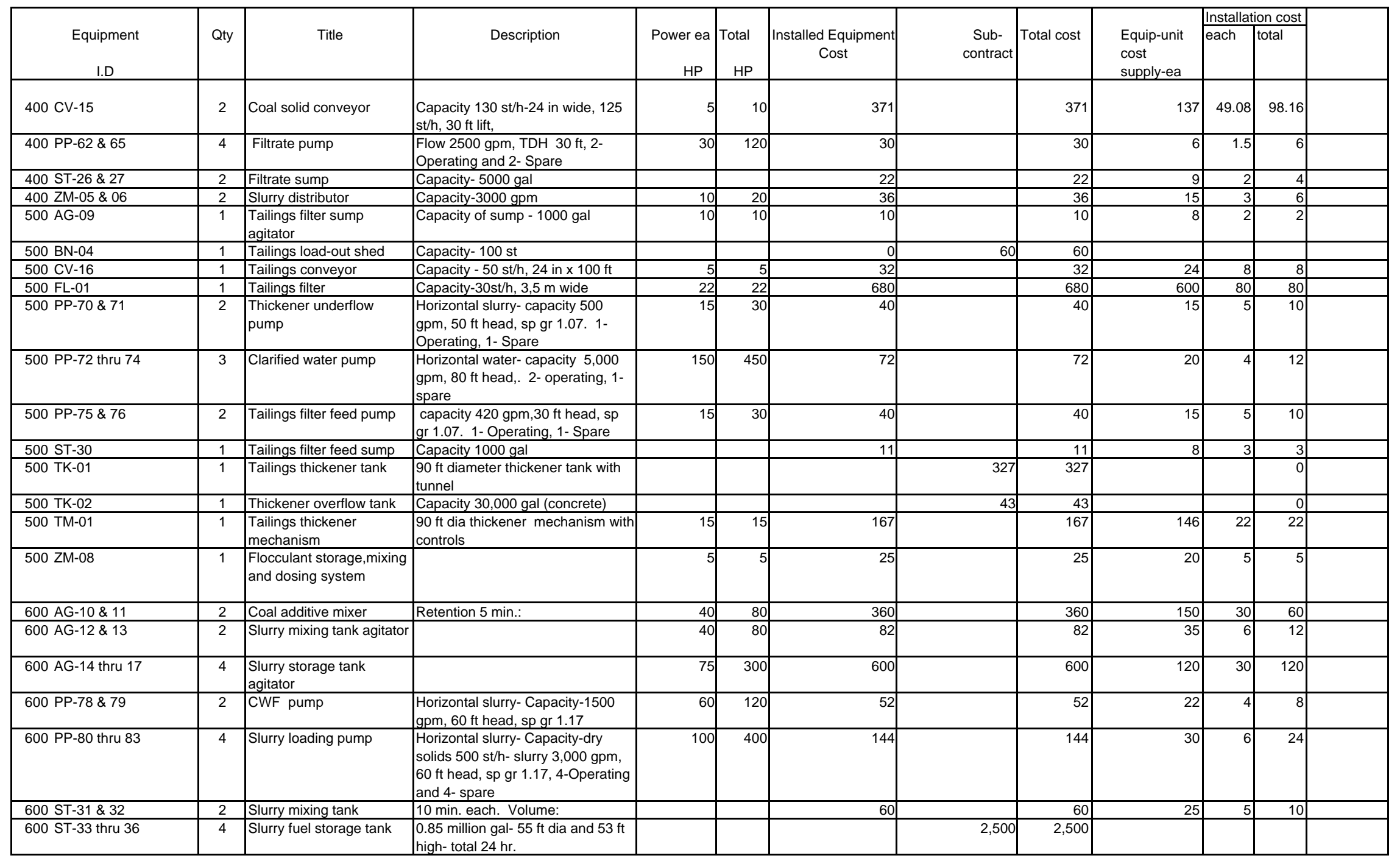




\section{APPENDIX B}

PREMIUM CWF PRODUCTION FACILITY - AGGLOMERATION

Conceptual Cost Estimate All costs are $\$ \times 1000$

\begin{tabular}{|c|c|c|c|c|c|c|c|c|c|c|c|}
\hline $\begin{array}{c}\text { Equipment } \\
\text { I.D }\end{array}$ & Qty & Title & Description & $\begin{array}{c}\text { Power ea } \\
\text { HP } \\
\end{array}$ & $\begin{array}{r}\text { Total } \\
\mathrm{HP} \\
\end{array}$ & $\begin{array}{c}\text { Installed Equipment } \\
\text { Cost }\end{array}$ & $\begin{array}{c}\text { Sub- } \\
\text { contract }\end{array}$ & Total cost & $\begin{array}{l}\text { Equip-unit } \\
\text { cost } \\
\text { supply-ea }\end{array}$ & \begin{tabular}{|l|l|}
\multicolumn{2}{|l|}{ Installatic } \\
each
\end{tabular} & \begin{tabular}{l|} 
ion cost \\
total
\end{tabular} \\
\hline $600 \mathrm{ZM}-10 \& 11$ & 2 & $\begin{array}{l}\text { Flocculant storage, mixing } \\
\text { and dosing system }\end{array}$ & & 10 & 20 & 140 & & 140 & 50 & 20 & 40 \\
\hline \multicolumn{5}{|c|}{ TOTAL MAJOR EQUIPMENT } & 26684 & 25,894 & 15,254 & 41,148 & & & 3431 \\
\hline
\end{tabular}

Summary

\begin{tabular}{|c|c|c|c|c|c|c|c|c|}
\hline \multirow{2}{*}{\multicolumn{4}{|c|}{ Total Major Equipment }} & \multirow{2}{*}{$\begin{array}{r}\text { Equipment } \\
22,464\end{array}$} & \multirow[t]{2}{*}{ Bulks } & \multirow{2}{*}{$\begin{array}{r}\text { Labor } \\
\mathbf{3 . 4 3 1}\end{array}$} & \multirow{2}{*}{\begin{tabular}{|l|}
$S C$ \\
15.254 \\
\end{tabular}} & \multirow{2}{*}{$\begin{array}{c}\text { Total } \\
\mathbf{4 1 , 1 4 8}\end{array}$} \\
\hline & & & & & & & & \\
\hline & & $\%$ & & & & & & \\
\hline J & Instruments & 8 & & & 1,797 & 540 & & 2,337 \\
\hline $\mathrm{L}$ & Piping & 10 & & & 2,246 & 1,481 & & 3,728 \\
\hline $\bar{M}$ & Structurals & 14 & & & 3,145 & 1,414 & & 4,559 \\
\hline $\mathrm{N}$ & $\begin{array}{l}\text { Insulation and Fire } \\
\text { protection }\end{array}$ & 3 & & & 674 & 444 & & 1,118 \\
\hline$P$ & Electrical & 14 & & & 3,145 & 2,358 & & 5,503 \\
\hline $\mathrm{Q}$ & Concrete & 13 & & & 2,920 & 3,593 & & 6,514 \\
\hline $\mathrm{R}$ & Building & 5 & & & & & 1,123 & 1,123 \\
\hline $\mathrm{S}$ & Site work & 3 (incuding internal roads) & & & 674 & 832 & & 1,505 \\
\hline $\mathrm{X}$ & Painting & 1 & & & & & 225 & 225 \\
\hline & I Bulk Materials & 71 & & 22,464 & 14,601 & 10.663 & 1.348 & 26,612 \\
\hline \multicolumn{3}{|c|}{ Freight } & 0.03 & 674 & & & & 674 \\
\hline \multicolumn{3}{|c|}{ Total Direct Field Costs } & & 23,137 & 14,601 & 14,094 & 16,602 & 68,434 \\
\hline \multicolumn{3}{|c|}{ Indirect Field Costs } & 60 & & & & & 8,456 \\
\hline \multicolumn{3}{|c|}{ Total Field Costs } & & & & & & 76,891 \\
\hline \multicolumn{3}{|c|}{ Home Office and Engineering } & 7 & & & & & 4,790 \\
\hline \multicolumn{3}{|c|}{ Total Installed Plant Costs less Contingency } & & & & & & 81,681 \\
\hline \multicolumn{3}{|c|}{ Contingency } & 17.72 & & & & & 14,472 \\
\hline \multicolumn{3}{|c|}{ Total Installed Plant Costs Including Contingency } & & & & & & 96,153 \\
\hline
\end{tabular}




\section{APPENDIX B}

PREMIUM CWF PRODUCTION FACILITY - AGGLOMERATION

Conceptual Cost Estimate

All costs are $\$ \times 1000$

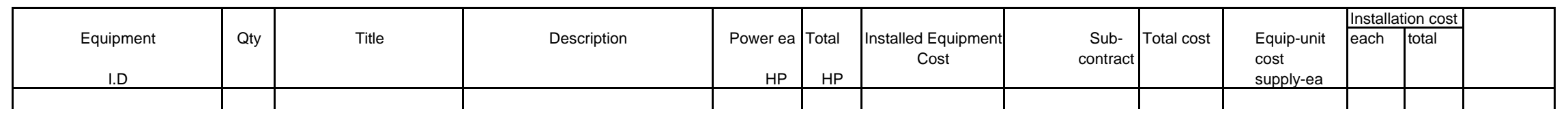

Cost Breakdown

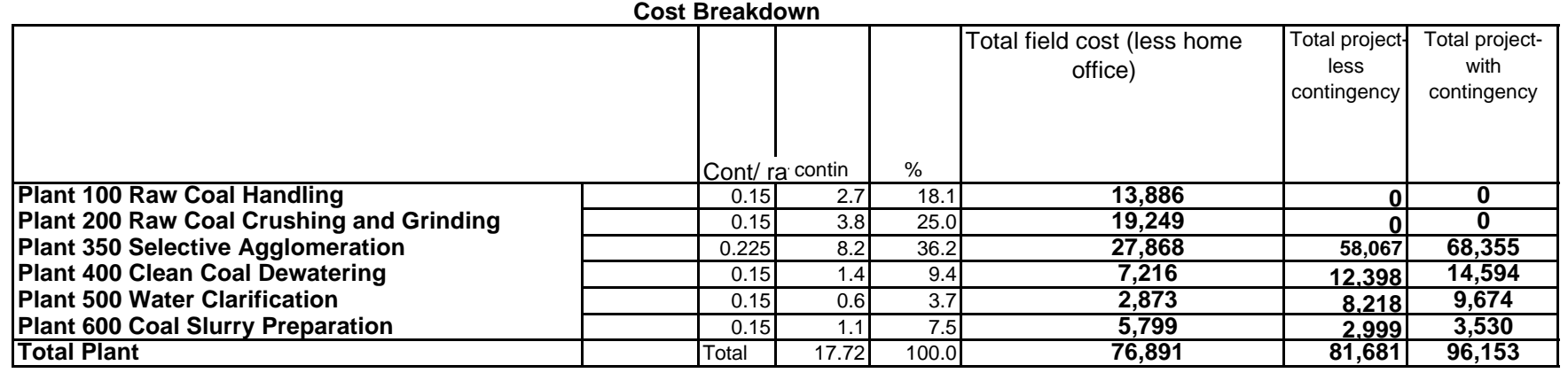


APPENDIX C

CWF COST SENSITIVITY CALCULATIONS - COLUMN FLOTATION

Table C-1

Changes in Coal Feed Rates and Tailings Generation for the Same Output

\begin{tabular}{|c|c|c|c|c|c|}
\hline CASE & & Base & Low & High & Remarks \\
\hline Item A-(1) & $\begin{array}{l}\text { Variation in Feed Ash } \\
\text { Ash in Feed Coal (Dry basis) wt\% } \\
\text { Feed Coal HV (Dry basis) Btu/lb } \\
\text { Clean coal ash - (Dry basis) wt \% } \\
\text { Clean Coal HV (Dry basis) Btu/lb } \\
\text { lb Ash /MBtu } \\
\text { Heating value recovery -\% } \\
\text { Weight recovery-\% } \\
\text { Feed coal st/st of Clean Coal } \\
\text { Feed coal wt as proportion of base case } \\
\quad \text { st/st of clean coal } \\
\text { Tailings } \\
\text { Tailings generation as proportion of base } \\
\text { Variation in heating value losses } \\
\text { Ash in Feed Coal (Dry basis) wt\% } \\
\text { Heating value losses - } \% \\
\text { Heating value recovery -\% } \\
\text { Feed Coal HV (Dry basis) } \\
\text { Clean Coal HV (Dry basis) } \\
\text { Weight recovery-\% } \\
\text { Feed coal st/st of Clean Coal } \\
\text { Feed coal wt as proportion of Base case }\end{array}$ & $\begin{array}{r}7.5 \\
14,054 \\
2.7 \\
14,962 \\
1.8 \\
96.1 \\
90.3 \\
1.11 \\
1.00 \\
\\
\\
0.11 \\
1.00 \\
\\
\\
7.5 \\
3.9 \\
96.1 \\
14,054 \\
14,962 \\
90.3 \\
1.11 \\
1.00\end{array}$ & $\begin{array}{r}3.75 \\
14,763 \\
2.7 \\
14,962 \\
1.8 \\
96.1 \\
94.9 \\
1.05 \\
0.95 \\
\\
\\
0.05 \\
0.50 \\
\\
\\
7.5 \\
1.9 \\
98.1 \\
14,054 \\
14,962 \\
92.1 \\
1.09 \\
0.98\end{array}$ & $\begin{array}{r}11.25 \\
13,346 \\
2.7 \\
14,962 \\
1.8 \\
96.1 \\
85.8 \\
1.17 \\
1.05 \\
\\
\\
0.17 \\
1.55 \\
\\
\\
7.5 \\
5.8 \\
94.2 \\
14,054 \\
14,962 \\
88.5 \\
1.13 \\
1.02\end{array}$ & $\begin{array}{l}\text { (+) or (-) } 50 \% \text { over Base } \\
\text { HV'=15472-Ash\%*189 } \\
\text { same in all cases- assumed } \\
\text { Effect Capital: on raw coal handling, } \\
\text { grinding, flotation 0\&M grinding power, } \\
\text { flotation reagents } \\
\text { Capital: refuse filter and thickener; O\&M } \\
\text { flocculants, Refuse disposal } \\
\text { No change } \\
\text { (+) or (-) } 50 \% \text { over Base } \\
\text { Based on feed coal Btu } \\
\text { Effect Capital : on raw coal handling, } \\
\text { grinding, flotation } 0 \& M \text { grinding power, } \\
\text { flotation reagents-Both Negligible } \\
\text { flocculants, Refuse disposal } \\
\text { O\&M cost Btu loss- to be accounted }\end{array}$ \\
\hline
\end{tabular}




\section{APPENDIX C \\ Table C-2 \\ CWF COST SENSITIVITY CALCULATIONS - COLUMN FLOTATION \\ IMPACTS ON CAPITAL COSTS}

\begin{tabular}{|c|c|c|c|c|c|}
\hline & & $\begin{array}{l}\text { Base } \\
\text { Case }\end{array}$ & $\begin{array}{l}\text { Low } \\
\text { Case }\end{array}$ & $\begin{array}{l}\text { High } \\
\text { Case }\end{array}$ & Remarks \\
\hline $\begin{array}{l}\text { I Capital Cost Impacts } \\
\text { A (i) Variations in Feed Coal ash content- wt \% } \\
\text { Ash in Feed Coal (Dry Basis) } \\
\text { Coal feed and Processing rate (Table C-1) } \\
\text { Tailings generation as proportion of base coal (Table C- } \\
\text { Capital cost-Crushing, Grinding and Flotation } \\
\text { Capital cost- Water clarification \& Tailings Handling } \\
\text { Rest of plant } \\
\text { Total Project Capital Cost } \\
\text { Capital Cost Impact } \\
\text { A (ii) Variations in Loss in Btu } \\
\text { Btu losses } \\
\text { Coal feed and Processing rate (Table C-1) } \\
\text { Refuse generation rate (Table C-1) } \\
\text { Capital cost-Crushing, Grinding and Flotation } \\
\text { Capital cost- Water clarification \& Tailings Handling } \\
\text { Rest of plant } \\
\text { Total Project Capital Cost } \\
\text { Capital Cost Impact }\end{array}$ & $\begin{array}{r}\% \\
\text { Ratios } \\
\% \\
\$ \times 1000 \\
\$ \times 1000 \\
\$ \times 1000 \\
\$ \times 1000 \\
\$ \times 1000 \\
\\
\text { Ratios } \\
\text { Ratios } \\
\$ \times 1000 \\
\$ \times 1000 \\
\$ \times 1000 \\
\$ \times 1000 \\
\$ \times 1000\end{array}$ & $\begin{array}{c}7.5 \\
1.00 \\
1.00 \\
33,135 \\
3,135 \\
33,312 \\
69,581 \\
\text { Base } \\
\\
\\
1.00 \\
1.00 \\
33,135 \\
3,135 \\
33,312 \\
69,581 \\
\text { Base }\end{array}$ & $\begin{array}{r}3.8 \\
0.952 \\
0.50 \\
32,012 \\
1,942 \\
33,312 \\
67,266 \\
-2,316 \\
\\
1.95 \\
0.98 \\
0.80 \\
33,135 \\
2,674 \\
33,312 \\
69,121 \\
-461\end{array}$ & $\begin{array}{r}11.25 \\
1.053 \\
1.55 \\
34,355 \\
4,255 \\
33,312 \\
71,922 \\
2,341 \\
\\
7.5 \\
1.02 \\
1.21 \\
33,135 \\
3,585 \\
33,312 \\
70,032 \\
450\end{array}$ & $\begin{array}{l}\text { Variation }+/-50 \% \\
\mathrm{C} 2=\mathrm{C} 1^{*}(\mathrm{Q} 2 / \mathrm{Q} 1)^{\wedge} .7 \\
\mathrm{C} 2=\mathrm{C} 1^{*}(\mathrm{Q} 2 / \mathrm{Q} 1)^{\wedge} .7 \\
\text { Variation }(+) 100 \text { to }(-) 50 \% \\
\text { Negligibe change } \\
\mathrm{C} 2=\mathrm{C} 1{ }^{*}(\mathrm{Q} 2 / \mathrm{Q} 1)^{\wedge} .7\end{array}$ \\
\hline
\end{tabular}




\section{APPENDIXC}

CWF COST SENSITIVITY CALCULATIONS - COLUMN FLOTATION

Case $A$ (i) and A (ii) Process Parameters

Case B (i) Price of Feed Coal

Variable and Fixed $O \&$ M Costs- Cost of CWF

\begin{tabular}{|c|c|c|c|c|c|c|c|c|c|c|c|c|c|c|c|c|c|c|c|c|c|}
\hline \multirow[b]{3}{*}{ Cost element } & \multicolumn{3}{|c|}{ Cost of CWF Base } & \multicolumn{6}{|c|}{ Cost of CWF Case A (i)-Ash in Feed Coal } & \multicolumn{6}{|c|}{ Cost of CWF Case A (ii)-Loss of Btu } & \multicolumn{6}{|c|}{ Cost of CWF Case B (i)-Coal Price } \\
\hline & \multirow[b]{2}{*}{$1000 \times \$ / y$} & \multirow{2}{*}{$\begin{array}{c}\$ / \mathrm{st} \\
\text { product } \\
\text { coal }\end{array}$} & \multirow[b]{2}{*}{ \$/MBtu } & \multicolumn{3}{|c|}{ Low } & \multicolumn{3}{|c|}{ High } & \multicolumn{3}{|c|}{ Low } & \multicolumn{3}{|c|}{ High } & \multicolumn{3}{|c|}{ Low } & \multicolumn{3}{|c|}{ High } \\
\hline & & & & Factor & $1000 \times \$ / y$ & $\$ / \mathrm{MBtu}$ & Factor & $1000 \times \$ / y$ & $\$ / M B t u$ & Factor & $1000 \times \$ / y$ & $\$ / \mathrm{MBtu}$ & Factor & $1000 \times \$ / y$ & $\$ / \mathrm{MBtu}$ & Factor & $1000 \times \$ / / y$ & $\$$ MBtu & Factor & $1000 \times \$ / y$ & \$/MBtu \\
\hline Variable O\&M Costs & & & & & & & & & & & & & & & & & & & & & \\
\hline Collector & 249 & 0.17 & 0.01 & 0.95 & 237 & 0.01 & 1.05 & 262 & 0.01 & 0.98 & 244 & 0.01 & 1.02 & 254 & 0.01 & 1.00 & 249 & 0.01 & 1.00 & 249 & \\
\hline Fother & 1,059 & 0.71 & 0.02 & 0.95 & 1,008 & 0.02 & 1.05 & 1,115 & 0.02 & 0.98 & 1,038 & 0.02 & 1.02 & 1,081 & 0.02 & 1.00 & 1,059 & 0.02 & 1.00 & 1,059 & 0.02 \\
\hline Flocculant & 1,764 & 1.18 & 0.04 & 0.50 & 890 & 0.02 & 1.55 & 2,729 & 0.06 & 0.80 & 1,406 & 0.03 & 1.21 & 2,137 & 0.05 & 1.00 & 1,764 & 0.04 & 1.00 & 1,764 & 0.04 \\
\hline CWF additive & 10,500 & 7.00 & 0.23 & 1.00 & 10,500 & 0.23 & 1.00 & 10,500 & 0.23 & 1.00 & 10,500 & 0.23 & 1.00 & 10,500 & 0.23 & 1.00 & 10,500 & 0.23 & 1.00 & 10,500 & 0.2 \\
\hline O\&M supplies and ball charge & 1,272 & 0.85 & 0.03 & 0.97 & 1,229 & 0.03 & 1.03 & 1,314 & 0.03 & 0.99 & 1,263 & 0.03 & 1.01 & 1,280 & 0.03 & 1.00 & 1,272 & 0.03 & 1.00 & 1,272 & 0.0 \\
\hline Electric power & 5,023 & 3.35 & 0.11 & 0.95 & 4,781 & 0.11 & 1.05 & 5,289 & 0.12 & 0.98 & 4,924 & 0.11 & 1.02 & 5,126 & 0.11 & 1.00 & 5,023 & 0.11 & 1.00 & 5,023 & 0.11 \\
\hline Water & 136 & 0.09 & 0.00 & 1.00 & 136 & 0.00 & 1.00 & 136 & 0.00 & 1.00 & 136 & 0.00 & 1.00 & 136 & 0.00 & 1.00 & 136 & 0.00 & 1.00 & 136 & 0.0 \\
\hline Refuse (tailings) disposal & 806 & 0.54 & 0.02 & 0.50 & 406 & 0.01 & 1.55 & 1,246 & 0.03 & 0.80 & 642 & 0.01 & 1.21 & 976 & 0.02 & 1.00 & 806 & 0.02 & 1.00 & 806 & 0.0 \\
\hline Btu loss & 2,243 & 1.50 & 0.05 & 1.00 & 2,243 & 0.05 & 1.00 & 2,243 & 0.05 & 1.00 & 2,243 & 0.05 & 1.00 & 2,243 & 0.05 & 0.90 & 2,019 & 0.045 & 1.10 & 2,468 & 0.05 \\
\hline Total Variable O \& M Costs & 23,052 & 15.37 & 0.51 & -3 & 21,432 & 0.48 & 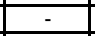 & 24,836 & 0.55 & $-\quad-1$ & 22,396 & 0.50 & - & 23733 & 0.53 & - & 22,827 & 0.51 & - & 23,276 & 0.52 \\
\hline Fixed O \& & & & & & & & & & & & & & & & & & & & & & \\
\hline Labor & 6,075 & 4.05 & 0.14 & 1.00 & 6,075 & 0.14 & 1.00 & 6,075 & 0.14 & 1.00 & 6,075 & 0.14 & 1.00 & 6,075 & 0.14 & 1.00 & 6,075 & 0.14 & 1.00 & 6,075 & 0.14 \\
\hline Capital Ch & 11,916 & 7.94 & 0.27 & 0.97 & 11,520 & 0.26 & 1.03 & 12,317 & 0.27 & 0.99 & 11,837 & 0.26 & 1.01 & 11,993 & 0.27 & 1.00 & 11,916 & 0.27 & 1.00 & 11,916 & 0.27 \\
\hline Total Fixed O \& M Costs & 17,991 & 11.99 & 0.40 & & 17,595 & 0.39 & & 18,392 & 0.41 & & 17,912 & 0.40 & & 18,068 & 0.40 & & 17,991 & 0.40 & & 17,991 & 0.40 \\
\hline & & & & & & & & & & & & & & & & & & & & & \\
\hline Total 0 \& M Costs & $\overline{043}$ & 27.36 & 0.91 & & 026 & 0.87 & & 43,228 & 0.96 & & 40,309 & 0.90 & & 41,801 & 0.931 & & 40,819 & 0.91 & & 41,267 & 0.92 \\
\hline Raw Coal & 55,807 & 37.20 & 1.2433 & 1.00 & 55,807 & 1.24 & 1.00 & 55,807 & 1.24 & 1.00 & 55,807 & 1.24 & 1.00 & 55,807 & \begin{tabular}{c|c|}
1.24 \\
\end{tabular} & 0.90 & 50,226 & 1.119 & 1.10 & 61,388 & 1.37 \\
\hline Total Premium CWF & 96,850 & 64.57 & 2.1577 & & 94,833 & 2.11 & & 99,035 & 2.21 & & 96,116 & 2.14 & & 97,608 & 2.17 & & 91 & 2.0284 & & 102,655 & 2.2 \\
\hline
\end{tabular}




\section{APPENDIX C}

Table C-4

CWF COST SENSITIVITY CALCULATIONS - COLUMN FLOTATION

Case B (ii) Labor, Case B (iii) Electricity, Case B (iv) Reagents and Additives

\begin{tabular}{|c|c|c|c|c|c|c|c|}
\hline \multirow[b]{2}{*}{ Case I. D } & \multirow{2}{*}{$\begin{array}{c}\text { Cost } \\
\text { Element }\end{array}$} & \multicolumn{2}{|c|}{ Variation } & \multicolumn{2}{|c|}{ Base Case } & \multirow{2}{*}{$\begin{array}{c}\text { Increase/ } \\
\text { Decrease } \\
\text { \$/MBtu }\end{array}$} & \multirow{2}{*}{$\begin{array}{c}\text { Revised } \\
\text { Cost of CWF } \\
\$ / \mathrm{MBtu}\end{array}$} \\
\hline & & Type & $\%$ & $\begin{array}{c}\text { Total } \\
\$ / \mathrm{MBtu}\end{array}$ & $\begin{array}{l}\text { Element } \\
\$ / \mathrm{MBtu}\end{array}$ & & \\
\hline \multirow[t]{2}{*}{ Case B (ii) } & \multirow[t]{2}{*}{ Labor } & Low & $-10 \%$ & 2.16 & 0.135 & -0.014 & 2.14 \\
\hline & & High & $10 \%$ & 2.16 & 0.135 & 0.014 & 2.17 \\
\hline \multirow[t]{2}{*}{ Case B (iii) } & \multirow[t]{2}{*}{ Electricity } & Low & $-10 \%$ & 2.16 & 0.112 & -0.011 & 2.15 \\
\hline & & High & $10 \%$ & 2.16 & 0.112 & 0.011 & 2.17 \\
\hline \multirow[t]{2}{*}{ Case B (iv) } & \multirow{2}{*}{$\begin{array}{c}\text { Reagents \& } \\
\text { Additives }\end{array}$} & Low & $-10 \%$ & 2.16 & 0.263 & -0.026 & 2.13 \\
\hline & & High & $10 \%$ & 2.16 & 0.263 & 0.026 & 2.18 \\
\hline
\end{tabular}




\section{APPENDIX C}

Table C - 5

CWF COST SENSITIVITY CALCULATIONS - COLUMN FLOTATION

Case C (i) Lower or Higher Plant Production- Same Operating Schedule

Case C (ii) Reduced Plant Production Due to fewer Operating Shifts

\begin{tabular}{|c|c|c|c|c|c|c|c|c|c|}
\hline \multirow{3}{*}{ Case I. D } & \multicolumn{2}{|c|}{ Production } & \multicolumn{2}{|c|}{ Variable O\&M } & \multicolumn{2}{|c|}{ Fixed O\&M } & \multicolumn{2}{|c|}{ Coal } & \multirow{3}{*}{$\begin{array}{c}\text { Revised } \\
\text { Cost of CWF } \\
\$ / M B t u\end{array}$} \\
\hline & Base & Variant & Base & Variant & Base & Variant & Base & Variant & \\
\hline & $10^{\wedge} 6 \mathrm{st} / \mathrm{y}$ & $10^{\wedge} 6 \mathrm{st} / \mathrm{y}$ & $\$ / \mathrm{MBtu}$ & $\$ / \mathrm{MBtu}$ & \$/MBtu & \$/MBtu & $\$ / \mathrm{MBtu}$ & $\$ / \mathrm{MBtu}$ & \\
\hline Case C (i)-Low & 1.5 & 1.35 & 0.51 & 0.51 & 0.40 & 0.45 & 1.24 & 1.24 & 2.20 \\
\hline Case C (i)-High & 1.5 & 1.65 & 0.51 & 0.51 & 0.40 & 0.36 & 1.24 & 1.24 & 2.12 \\
\hline
\end{tabular}

\begin{tabular}{|c|c|c|c|c|c|c|c|c|c|c|c|c|c|c|c|}
\hline \multirow{3}{*}{ Case I. D } & \multicolumn{2}{|c|}{ Production } & \multicolumn{2}{|c|}{ Schedule } & \multicolumn{2}{|c|}{ Employees } & \multicolumn{2}{|c|}{ Variable O\&M } & \multicolumn{2}{|c|}{ Labor } & \multicolumn{2}{|c|}{ Capital charges } & \multicolumn{2}{|c|}{ Coal } & \multirow{3}{*}{$\begin{array}{c}\text { Revised } \\
\text { Cost of CWF } \\
\text { \$/MBtu }\end{array}$} \\
\hline & Base & Variant & Base & Variant & Base & Variant & Base & Variant & Base & Variant & Base & Variant & Base & Variant & \\
\hline & $10^{\wedge} 6 \mathrm{st} / \mathrm{y}$ & $10^{\wedge} 6 \mathrm{st} / \mathrm{y}$ & sht/wk & sht/wk & No. & No. & $\$ / \mathrm{MBtu}$ & $\$ / \mathrm{MBtu}$ & $\$ /$ MBtu & $\$ / \mathrm{MBtu}$ & $\$ / \mathrm{MBtu}$ & $\$ /$ MBtu & $\$ / \mathrm{MBtu}$ & $\$ / \mathrm{MBtu}$ & \\
\hline Case C (ii)-Low & 1.5 & 0.79 & 19 & 10 & 81 & 44 & 0.51 & 0.51 & 0.14 & 0.14 & 0.27 & 0.50 & 1.24 & 1.24 & 2.40 \\
\hline Case C (ii)- High & 1.5 & 1.18 & 19 & 15 & 81 & 64 & 0.51 & 0.51 & 0.14 & 0.14 & 0.27 & 0.34 & 1.24 & 1.24 & 2.23 \\
\hline
\end{tabular}

Case D (i), D (ii) Lower or Higher Capital Costs

\begin{tabular}{|c|c|c|c|c|c|c|}
\hline & \multicolumn{2}{|c|}{ Capital Cost } & \multirow{3}{*}{$\begin{array}{c}\text { Base } \\
\text { Cost of CWF } \\
\text { \$/MBtu }\end{array}$} & \multicolumn{2}{|c|}{ Capital charges } & \multirow{3}{*}{$\begin{array}{c}\text { Revised } \\
\text { Cost of CWF } \\
\$ / \mathrm{MBtu}\end{array}$} \\
\hline & \multirow{2}{*}{\begin{tabular}{|c|} 
Base \\
$\$ \times 1000$ \\
\end{tabular}} & \multirow{2}{*}{$\frac{\text { Variant }}{\%}$} & & \multirow{2}{*}{$\begin{array}{l}\text { Base } \\
/ \text { MBtu }\end{array}$} & \multirow{2}{*}{$\begin{array}{l}\text { Variant } \\
\text { \$MBtu }\end{array}$} & \\
\hline & & & & & & \\
\hline Case D (i)-Low & 69,581 & $-10 \%$ & 2.158 & 0.265 & -0.027 & 2.131 \\
\hline Case D (i)- High & 69,581 & $20 \%$ & 2.158 & 0.265 & 0.053 & 2.211 \\
\hline
\end{tabular}


APPENDIX D

Table D-1

SENSITIVITY CALCULATIONS- AGGLOMERATION

Changes in Coal Feed Rates and Tailings Generation for the Same Output

\begin{tabular}{|c|c|c|c|c|c|}
\hline CASE & & Base & Low & High & Remarks \\
\hline Item A-(2) & $\begin{array}{l}\text { Variation in Feed Ash } \\
\text { Ash in Feed Coal (Dry basis) wt\% } \\
\text { Feed Coal HHV (Dry basis) Btu/lb } \\
\text { Clean coal ash - (Dry basis) wt \% } \\
\text { Clean Coal HHV (Dry basis) Btu/lb } \\
\text { lb Ash /MBtu } \\
\text { Heating value recovery -\% } \\
\text { Weight recovery-\% } \\
\text { Feed coal st/st of Clean Coal } \\
\text { Feed coal wt as proportion of base case } \\
\quad \text { st/st of clean coal } \\
\text { Tailings } \\
\text { Tailings generation as proportion of base } \\
\text { Variation in heating value losses } \\
\text { Ash in Feed Coal (Dry basis) wt\% } \\
\text { Heating value losses - } \% \\
\text { Heating value recovery - } \% \\
\text { Feed Coal HHV (Dry basis) } \\
\text { Clean Coal HHV (Dry basis) } \\
\text { Weight recovery-\% } \\
\text { Feed coal st/st of Clean Coal } \\
\text { Feed coal wt as proportion of Base case }\end{array}$ & $\begin{array}{r}7.5 \\
14,054 \\
2.7 \\
14,962 \\
1.8 \\
99.0 \\
93.0 \\
1.08 \\
1.00 \\
\\
\\
0.08 \\
1.00 \\
\\
\\
7.5 \\
1 \\
99 \\
14,054 \\
14,962 \\
93.0 \\
1.08 \\
1.00\end{array}$ & $\begin{array}{r}3.75 \\
14,763 \\
2.7 \\
14,962 \\
1.8 \\
99.0 \\
97.7 \\
1.02 \\
0.95 \\
\\
\\
0.02 \\
0.31 \\
\\
\\
\\
7.5 \\
0.5 \\
99.5 \\
14,054 \\
14,962 \\
93.5 \\
1.07 \\
0.99\end{array}$ & $\begin{array}{r}11.25 \\
13,346 \\
2.7 \\
14,962 \\
1.8 \\
99.0 \\
88.3 \\
1.13 \\
1.05 \\
\\
\\
0.13 \\
1.76 \\
\\
\\
7.5 \\
1.5 \\
98.5 \\
14,054 \\
14,962 \\
92.5 \\
1.08 \\
1.01 \\
\end{array}$ & $\begin{array}{l}\text { (+) or (-) } 50 \% \text { over Base } \\
\text { HHV'= } 15472-\text { Ash\%* } 189 \\
\text { same in all cases- assumed } \\
\text { Effect Capital: on raw coal handling, } \\
\text { grinding, flotation 0\&M grinding power, } \\
\text { flotation reagents } \\
\text { Capital: refuse filter and thickener; } \\
\text { O\&M flocculants, Refuse disposal } \\
\text { No change } \\
\text { (+) or (-) } 50 \% \text { over Base } \\
\text { Based on feed coal Btu } \\
\text { Capital: refuse filter and thickener; } \\
\text { O\&M flocculants, Refuse disposal } \\
\text { O\&M cost Btu loss- to be accounted } \\
\text { Effect Capital : on raw coal handling, } \\
\text { grinding, flotation 0\&M grinding power, } \\
\text { flotation reagents-Both Negligible }\end{array}$ \\
\hline
\end{tabular}


APPENDIX D

Table D-2

SENSITIVITY CALCULATIONS- AGGLOMERATION

CAPITAL COST IMPACTS

\begin{tabular}{|c|c|c|c|c|c|}
\hline & & $\begin{array}{l}\text { Base } \\
\text { Case }\end{array}$ & $\begin{array}{l}\text { Low } \\
\text { Case }\end{array}$ & $\begin{array}{l}\text { High } \\
\text { Case }\end{array}$ & Remarks \\
\hline $\begin{array}{l}\text { I Capital Cost Impacts } \\
\text { A (i) Variations in Feed Coal ash content- wt \% } \\
\text { Ash in Feed Coal (Dry Basis) } \\
\text { Coal feed and Processing rate (Table D-1) } \\
\text { Tailings generation as proportion of base (Table D-1) } \\
\text { Capital cost-Crushing, Grinding and Flotation } \\
\text { Capital cost- Water clarification \& Tailings Handling } \\
\text { Rest of plant } \\
\text { Total plant } \\
\text { Capital Cost Impact } \\
\text { A (ii) Variations in Loss in Btu } \\
\text { Btu losses } \\
\text { Coal feed and Processing rate (Table D-1) } \\
\text { Tailings generation (Table D-1) } \\
\text { Capital cost- Water clarification \& Tailings Handling } \\
\text { Rest of plant } \\
\text { Total plant } \\
\text { Capital Cost Impact }\end{array}$ & \begin{tabular}{|c}
$\begin{array}{r}\% \\
\text { Ratios } \\
\text { Ratios }\end{array}$ \\
$\$ \times 1000$ \\
$\$ \times 1000$ \\
$\$ \times 1000$ \\
$\$ \times 1000$ \\
$\$ \times 1000$ \\
$\%$ \\
Ratios \\
Ratios \\
$\$ \times 1000$ \\
$\$ \times 1000$ \\
$\$ \times 1000$ \\
$\$ \times 1000$
\end{tabular} & $\begin{array}{c}7.5 \\
\mathbf{1 . 0 0} \\
\mathbf{1 . 0 0} \\
33,135 \\
2,873 \\
61,227 \\
97,235 \\
\text { Base } \\
\\
1.00 \\
1.00 \\
1.00 \\
2,873 \\
94,361 \\
97,235 \\
\text { Base }\end{array}$ & $\begin{array}{r}3.75 \\
0.952 \\
0.31 \\
32,012 \\
1,278 \\
61,227 \\
94,517 \\
-\mathbf{2}, 718 \\
\\
0.50 \\
0.99 \\
0.93 \\
2,728 \\
94,361 \\
97,089 \\
-146\end{array}$ & $\begin{array}{r}11.25 \\
\mathbf{1 . 0 5 3} \\
\mathbf{1 . 7 6} \\
34,355 \\
4,263 \\
61,227 \\
99,845 \\
\mathbf{2 , 6 1 0} \\
\\
2.00 \\
1.01 \\
1.07 \\
3,018 \\
94,361 \\
97,379 \\
144\end{array}$ & $\begin{array}{l}\text { Variation }+/-50 \% \\
\mathrm{C} 2=\mathrm{C} 1^{*}(\mathrm{Q} 2 / \mathrm{Q} 1)^{\wedge} .7 \\
\mathrm{C} 2=\mathrm{C}^{*}(\mathrm{Q} 2 / \mathrm{Q} 1)^{\wedge} .7 \\
\text { Variation }(+) 100 \text { to }(-) 50 \% \\
\text { Negligible changes in these pl } \\
\mathrm{C} 2=\mathrm{C} 1^{*}(\mathrm{Q} 2 / \mathrm{Q} 1)^{\wedge} .7\end{array}$ \\
\hline
\end{tabular}




\section{APPENDIX D}

SENSITIVITY CALCULATIONS - AGGLOMERATION

Case A (i) and A (ii) Process Parameter Variations

Variable and Fixed $O \&$ M Costs- Cost of CWF

\begin{tabular}{|c|c|c|c|c|c|c|c|c|c|c|c|c|c|c|c|c|c|c|c|c|c|}
\hline \multirow[b]{3}{*}{ Cost element } & \multirow{2}{*}{\multicolumn{3}{|c|}{ Cost of CWF Base }} & \multirow{2}{*}{\multicolumn{6}{|c|}{ Cost of CWF Case A (i)-Ash in Feed Coal }} & \multirow{2}{*}{\multicolumn{6}{|c|}{ Cost of CWF Case A (ii)-Loss of Btu }} & \multicolumn{6}{|c|}{ Cost of CWF Case B (i)- Coal Price } \\
\hline & & & & & Low & & & & & & & & & & & & Low & & & & \\
\hline & $1000 \times \$ / y$ & $\begin{array}{c}\text { product } \\
\text { coal }\end{array}$ & $\$ /$ MBtu & Factor & $1000 \times \$ / /$ & $\$ / M B t u$ & Factor & $1000 \times \$ / y$ & \$/MBtu & Factor & $1000 \times \$ / y$ & \$/MBtu & Factor & $1000 \times \$ /$ & $\$ / \mathrm{MBtu}$ & Factor & $1000 \times \$ /$ & \$/MBtu & Factor & $1000 \times \$ / y$ & $\$ / \mathrm{MBtu}$ \\
\hline \begin{tabular}{|l|} 
Variable O\&M Costs \\
Heptane
\end{tabular} & 1,524 & 1.02 & 0.03 & 0.95 & 1,451 & 0.03 & 1.05 & 1,605 & 0.04 & 0.99 & 1,517 & 0.03 & 1.01 & 1,532 & 0.03 & 1.00 & 1,524 & 0.03 & 1.00 & 1,524 & 0.03 \\
\hline Steam & 5,706 & 3.80 & 0.13 & 0.95 & 5,431 & 0.12 & 1.05 & 6,008 & 0.13 & 0.99 & 5,677 & 0.13 & 1.01 & 5,735 & 0.13 & 1.00 & 5,706 & 0.13 & $\begin{array}{l}1.00 \\
0.00\end{array}$ & $\begin{array}{r}5,706 \\
0\end{array}$ & $\begin{array}{l}0.13 \\
0.00\end{array}$ \\
\hline Flocculant & 1,238 & 0.83 & 0.03 & 0.31 & 389 & 0.01 & 1.76 & 2,175 & 0.05 & 0.93 & 1,149 & 0.03 & 1.07 & 1,328 & 0.03 & 1.00 & 1,238 & 0.03 & 1.00 & 1,238 & 0.03 \\
\hline & 10,500 & 7.00 & & 1.00 & 10,500 & 0.23 & 1.00 & 10,500 & 0.23 & 1.00 & 10,500 & 0.23 & 1.00 & 10,500 & 0.23 & 1.00 & 10,500 & 0.23 & 1.00 & 10,500 & 0.23 \\
\hline ball charge & 1,607 & 0.75 & 0.03 & 0.97 & 1,562 & 0.02 & 1.03 & 1,650 & 0.03 & 0.999 & 1,604 & 0.02 & 1.001 & 1,609 & 0.03 & 1.00 & 1,607 & 0.03 & 1.00 & 1,608 & 0.03 \\
\hline Electric power & 6,743 & 4.50 & 0.15 & 0.95 & 6,419 & 0.14 & 1.05 & 7,101 & 0.16 & 0.99 & 6,709 & 0.15 & 1.01 & 6,778 & 0.15 & 1.00 & 6,743 & 0.15 & 1.00 & 6,743 & 0.15 \\
\hline Water & 132 & 0.09 & 0.00 & 1.00 & 132 & 0.00 & 1.00 & 132 & 0.00 & 1.00 & 132 & 0.00 & 1.00 & 132 & 0.00 & 1.00 & 132 & 0.00 & 1.00 & 132 & 0.00 \\
\hline Refuse (tailings) disposal & 565 & 0.38 & 0.01 & 0.31 & 178 & 0.00 & 1.76 & 993 & 0.02 & 0.93 & 525 & 0.01 & 1.07 & 606 & 0.01 & 1.00 & 565 & 0.01 & 1.00 & 565 & 0.01 \\
\hline Btu loss & 564 & 0.38 & 0.01 & 1.00 & 564 & 0.01 & 1.00 & 564 & 0.01 & 1.00 & 564 & 0.01 & 1.00 & 564 & 0.01 & 0.90 & 507 & 0.011 & 1.10 & 620 & 0.01 \\
\hline Total Variable O \& M Costs & 28,579 & 18.73 & 0.63 & & 26,626 & 0.58 & 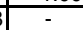 & 30,729 & 0.67 & & 28,377 & 0.62 & & 28783 & 0.63 & & 28,523 & 0.62 & 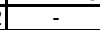 & 28,636 & 0.63 \\
\hline Fixed O \& M Costs & & & & & & & & & & & & & & & & & & & & & \\
\hline & 7,800 & 5.20 & 0.17 & 1.00 & 7,800 & 0.17 & 1.00 & 7,800 & 0.17 & 1.00 & 7,800 & 0.17 & 1.00 & 7,800 & 0.17 & 1.00 & 7,800 & 0.17 & 1.00 & 7,800 & 0.17 \\
\hline Capit & 16,414 & 10.94 & 0.37 & 0.97 & 15,955 & 0.36 & 1.03 & 16,855 & 0.38 & 1.00 & 16,390 & 0.37 & 1.00 & 16,439 & 0.37 & 1.00 & 16,414 & 0.37 & 1.00 & 16,414 & 0.37 \\
\hline Total Fixed O \& M Costs & 24,214 & 16.14 & 0.54 & & 23,755 & 0.53 & & 24,655 & 0.55 & & 24,190 & 0.54 & & 24,239 & 0.54 & & 24,214 & 0.54 & & 24,214 & 0.54 \\
\hline Total O \& M Costs & 7793 & 34.87 & 1117 & & 50,382 & 111 & & 55383 & 122 & & 52567 & 116 & & 53022 & 1170 & & 52737 & 116 & & 52850 & 117 \\
\hline Raw Coal & 55,807 & 37.20 & 1.24 & 1.00 & 55,807 & 1.24 & 1.00 & 55,807 & $\begin{array}{ll}1.24 \\
1.24\end{array}$ & 1.00 & 55,807 & 1.24 & 1.00 & 55,807 & $\frac{1.170}{1.24}$ & 0.90 & 50,226 & 1.12 & 1.10 & $\frac{2,0,050}{61,388}$ & 1.37 \\
\hline Total Premium CWF & 108,600 & 72.08 & 2.41 & & 106,189 & 2.36 & & 111,190 & 2.47 & & 108,374 & 2.40 & & 108,829 & 2.41 & & 102,963 & 2.28 & & 114,237 & 2.53 \\
\hline
\end{tabular}


APPENDIX D

Table D-4

SENSITIVITY CALCULATIONS- AGGLOMERATION

Case B (ii) Labor, Case B (iii) Electricity, Case B (iv) Reagents and Additives, Case B (v) Steam

\begin{tabular}{|c|c|c|c|c|c|c|c|}
\hline & \multirow{3}{*}{$\begin{array}{c}\text { Cost } \\
\text { Element }\end{array}$} & \multicolumn{2}{|c|}{ Variation } & \multicolumn{2}{|c|}{ Base Case } & \multirow{3}{*}{\begin{tabular}{|c|} 
Increase/ \\
Decrease \\
\$/MBtu
\end{tabular}} & \multirow{3}{*}{$\begin{array}{c}\text { Revised } \\
\text { Cost of CWF } \\
\$ / \mathrm{MBtu}\end{array}$} \\
\hline & & & & \multirow{2}{*}{$\begin{array}{c}\text { Total } \\
\$ / \mathrm{MBtu}\end{array}$} & \multirow{2}{*}{$\begin{array}{l}\text { Element } \\
\$ / \mathrm{MBtu}\end{array}$} & & \\
\hline & & Type & $\%$ & & & & \\
\hline \multirow[t]{2}{*}{ Case B (ii) } & \multirow[t]{2}{*}{ Labor } & Low & $-10 \%$ & 2.41 & 0.174 & \begin{tabular}{|l|}
-0.017 \\
\end{tabular} & 2.39 \\
\hline & & High & $10 \%$ & 2.41 & 0.174 & 0.017 & 2.43 \\
\hline \multirow[t]{2}{*}{ Case B (iii) } & \multirow[t]{2}{*}{ Electricity } & Low & $-10 \%$ & 2.41 & 0.150 & -0.015 & 2.39 \\
\hline & & High & $10 \%$ & 2.41 & 0.150 & 0.015 & 2.42 \\
\hline \multirow[t]{2}{*}{ Case B (iv) } & Reagents \& & Low & $-10 \%$ & 2.41 & 0.268 & -0.027 & 2.38 \\
\hline & Additives & High & $10 \%$ & 2.41 & 0.268 & 0.027 & 2.44 \\
\hline \multirow[t]{2}{*}{ Case B (v) } & \multirow[t]{2}{*}{ Steam } & Low & $-10 \%$ & 2.41 & 0.127 & -0.013 & 2.40 \\
\hline & & High & $10 \%$ & 2.41 & 0.127 & 0.013 & 2.42 \\
\hline
\end{tabular}




\section{APPENDIX D}

TE

\section{SENSITIVITY CALCULATIONS- AGGLOMERATION}

Case C (i) Lower or Higher Plant Production- Same Operating Schedule

Case C (ii) Reduced Plant Production Due to fewer Operating Shifts

\begin{tabular}{|c|c|c|c|c|c|c|c|c|c|}
\hline \multirow{3}{*}{ Case I. D } & \multicolumn{2}{|c|}{ Production } & \multicolumn{2}{|c|}{ Variable O\&M } & \multicolumn{2}{|c|}{ Fixed O\&M } & \multicolumn{2}{|c|}{ Coal } & \multirow{3}{*}{$\begin{array}{c}\text { Revised } \\
\text { Cost of CWF } \\
\$ / \mathrm{MBtu}\end{array}$} \\
\hline & Base & \begin{tabular}{|l|} 
Variant \\
\end{tabular} & Base & Variant & Base & Variant & Base & Variant & \\
\hline & $10^{\wedge} 6 \mathrm{st} / \mathrm{y}$ & $10^{\wedge} 6 \mathrm{st} / \mathrm{y}$ & \$/MBtu & \$/MBtu & $\$ / \mathrm{MBtu}$ & $\$ /$ MBtu & $\$ / \mathrm{MBtu}$ & $\$ / \mathrm{MBtu}$ & \\
\hline Case C (i)-Low & 1.5 & 1.35 & 0.63 & 0.63 & 0.54 & 0.60 & 1.24 & 1.24 & 2.47 \\
\hline Case C (i)-High & 1.5 & 1.65 & 0.63 & 0.63 & 0.54 & 0.49 & 1.24 & 1.24 & 2.36 \\
\hline
\end{tabular}

\begin{tabular}{|c|c|c|c|c|c|c|c|c|c|c|c|c|c|c|c|}
\hline \multirow{3}{*}{ Case I. D } & \multicolumn{2}{|c|}{ Production } & \multicolumn{2}{|c|}{ Schedule } & \multicolumn{2}{|c|}{ Employees } & \multicolumn{2}{|c|}{ Variable O\&M } & \multicolumn{2}{|c|}{ Labor } & \multicolumn{2}{|c|}{ Capital charges } & \multicolumn{2}{|c|}{ Coal } & \multirow{3}{*}{$\begin{array}{c}\text { Revised } \\
\text { Cost of CWF } \\
\$ / M B t u\end{array}$} \\
\hline & Base & Variant & Base & Variant & Base & Variant & Base & Variant & Base & Variant & Base & Variant & Base & Variant & \\
\hline & $10^{\wedge} 6 \mathrm{st} / \mathrm{y}$ & $10^{\wedge} 6 \mathrm{st} / \mathrm{y}$ & sht/wk & sht/wk & No. & No. & \$/MBtu & $\$ /$ MBtu & $\$ /$ MBtu & \$/MBtu & \$/MBtu & $\$ /$ MBtu & \$/MBtu & $\$ / \mathrm{MBtu}$ & \\
\hline Case C (ii)-Low & 1.5 & 0.69 & 19 & 10 & 104 & 54 & 0.63 & 0.63 & 0.17 & 0.20 & 0.37 & 0.79 & 1.24 & 1.24 & 2.86 \\
\hline Case C (ii)- High & 1.5 & 1.18 & 19 & 15 & 104 & 79 & 0.63 & 0.63 & 0.17 & 0.17 & 0.37 & 0.46 & 1.24 & 1.24 & 2.50 \\
\hline
\end{tabular}

Case D (i), D (ii) Lower or Higher Capital Costs

\begin{tabular}{|c|c|c|c|c|c|c|}
\hline \multirow{3}{*}{ Case I. D } & \multicolumn{2}{|c|}{ Capital Cost } & \multirow{3}{*}{$\begin{array}{c}\text { Base } \\
\text { Cost of CWF } \\
\$ / \mathrm{MBtu}\end{array}$} & \multicolumn{2}{|c|}{ Capital charges } & \multirow{3}{*}{$\begin{array}{c}\text { Revised } \\
\text { Cost of CWF } \\
\$ / \mathrm{MBtu}\end{array}$} \\
\hline & \begin{tabular}{|l|} 
Base \\
\end{tabular} & Variant & & Base & Variant & \\
\hline & $\$ \times 1000$ & $\%$ & & \$/MBtu & \$/MBtu & \\
\hline Case D (i)-Low & 97,235 & $-10 \%$ & 2.409 & 0.366 & 0.329 & 2.372 \\
\hline Case D (i)- High & 97,235 & $20 \%$ & 2.409 & 0.366 & 0.439 & 2.482 \\
\hline
\end{tabular}

